NBER WORKING PAPER SERIES

\title{
THE AGGREGATE CONSEQUENCES OF DEFAULT RISK: EVIDENCE FROM FIRM-LEVEL DATA
}

\author{
Timothy J. Besley \\ Isabelle A. Roland \\ John Van Reenen \\ Working Paper 26686 \\ http://www.nber.org/papers/w26686 \\ NATIONAL BUREAU OF ECONOMIC RESEARCH \\ 1050 Massachusetts Avenue \\ Cambridge, MA 02138 \\ January 2020
}

We would like to thank the Lamfalussy Fellowship of the European Central Bank, the Paul Woolley Centre, STICERD, the ESRC and award ES/L012103/1 made through DEGRP for financial support. For useful comments and discussions, we thank Alina Barnett, Nick Bloom, Mark Franklin, Jonathan Haskel, Simon Gilchrist, Michelle Jin, Ralf Martin, David Miles, Rebecca Riley, Rosa Sanchis-Guarner, Chad Syverson, David Thesmar, Garry Young, Daniel Xu, the UK Secure Data Service, and participants at various seminars. Disclaimer: The paper makes use of confidential data collected by the UK Office for National Statistics and securely provided by the UK Data Service. The use of these data does not imply the endorsement of the data owner or the UK Data Service at the UK Data Archive in relation to the interpretation or analysis of the data. This work uses research data sets which may not exactly reproduce National Statistics aggregates. The views expressed herein are those of the authors and do not necessarily reflect the views of the National Bureau of Economic Research.

At least one co-author has disclosed a financial relationship of potential relevance for this research. Further information is available online at http://www.nber.org/papers/w26686.ack

NBER working papers are circulated for discussion and comment purposes. They have not been peer-reviewed or been subject to the review by the NBER Board of Directors that accompanies official NBER publications.

(C) 2020 by Timothy J. Besley, Isabelle A. Roland, and John Van Reenen. All rights reserved. Short sections of text, not to exceed two paragraphs, may be quoted without explicit permission provided that full credit, including $(\odot$ notice, is given to the source. 
The Aggregate Consequences of Default Risk: Evidence from Firm-level Data

Timothy J. Besley, Isabelle A. Roland, and John Van Reenen

NBER Working Paper No. 26686

January 2020

JEL No. D24,E32,L11,O47

\begin{abstract}
This paper studies the implications of perceived default risk for aggregate output and productivity. Using a model of credit contracts with moral hazard, we show that a firm's probability of default is a sufficient statistic for capital allocation. The theoretical framework suggests an aggregate measure of the impact of credit market frictions based on firm-level probabilities of default which can be applied using data on firm-level employment and default risk. We obtain direct estimates of firm-level default probabilities using Standard and Poor's PD Model to capture the expectations that lenders were forming based on their historical information sets. We implement the method on the UK, an economy that was strongly exposed to the global financial crisis and where we can match default probabilities to administrative data on the population of 1.5 million firms per year. As expected, we find a strong correlation between default risk and a firm's future performance. We estimate that credit frictions (i) cause an output loss of around $28 \%$ per year on average; (ii) are much larger for firms with under 250 employees and (iii) that losses are overwhelmingly due to a lower overall capital stock rather than a misallocation of credit across firms with heterogeneous productivity. Further, we find that these losses accounted for over half of the productivity fall between 2008 and 2009, and persisted for smaller (although not larger) firms
\end{abstract}

Timothy J. Besley

Department of Economics

London School of Economics

Houghton Street

London WC2A 2AE ENGLAND

T.Besley@1se.ac.uk

Isabelle A. Roland

Department of Economics

Cambridge University

ir316@cam.ac.uk
John Van Reenen

Department of Economics, E62-518

MIT

50 Memorial Drive

Cambridge, MA 02142

and NBER

vanreene@mit.edu 


\section{Introduction}

The period following the global financial crisis of 2008-09 heightened awareness of the role of credit frictions in affecting economic efficiency, either due to a higher cost of capital and/or capital being misallocated away from its most productive uses. This paper develops a novel approach to assessing how default risk affects the economy. It combines a simple theoretical model of credit contracts, where the firm's default risk is a sufficient statistic for credit frictions, with a direct estimate of a firm's default risk using a tool actually used by lenders developed and sold by Standard and Poor's. We use this to look at the heterogeneous impact of assessed default at the firm level, as well as the aggregate implications of default risk by constructing a theoreticallyderived measure of output losses due to default risk.

We apply the framework to the UK where we have access to rich administrative panel data that we can match to firm-level probabilities of default (PD). Specifically, we obtain estimates of historical firm-level probabilities of default using Standard and Poor's PD Model and CreditPro. The PD Model is a tool which is widely used for firm-level credit scoring in financial markets and therefore reflects access to credit by firms. Similar to many other credit scoring tools, it uses a combination of financial accounts data, industry, and macroeconomic factors to assess the credit risk of a company. We use nearpopulation data on private and publicly listed companies (from Bureau Van Dijk's Orbis database) to construct a firm-specific time-varying estimate of default probabilities. This information is merged with an administrative data set containing the population of UK firms (the IDBR, Inter-Departmental Business Register).

Our basic method requires only information on employment and default probabilities, which is a distinct advantage over other approaches since firm population datasets such as the U.S. Longitudinal Business Database contain only basic information on firms (like employment) and not investment or value added. Our baseline results use the firm population, but we also exploit richer data from the Annual Business Inquiry and Annual Business Survey (ABI/ABS), which are stratified random samples across the whole of the UK private sector with measures of value added, intermediate inputs and capital expenditures. ${ }^{1}$ We show that even after controlling for firm fixed effects, a

\footnotetext{
${ }^{1}$ In the U.S., data on value added and investment is not generally available outside the manufacturing sector. Even in the manufacturing sector, Census data has intermediate goods inputs, but not intermediate service inputs.
} 
firm's probability of default is related to measures of performance such as size, capital investment and value added.

Our baseline macro results based on a sample of around 1.5 million firms each year from the IDBR suggest that credit frictions caused on average a $28 \%$ annual loss of GDP between 2005 and 2013 when compared to the frictionless benchmark, defined as a world without default risk. Exploiting firm-level heterogeneity, we show that credit frictions play a much larger role in depressing output and labor productivity among small and medium sized enterprises (SMEs). This is consistent with SMEs being more dependent on bank financing and facing tighter credit constraints than larger firms.

We then decompose aggregate credit frictions into two parts (i) a "scale effect" which estimates the impact of credit frictions on output through its effect on the aggregate stock of capital and labor inputs, while holding the joint distribution of frictions and productivity constant; and (ii) a "TFP effect" which estimates the impact of credit frictions on output holding the aggregate capital stock and labor input fixed. This decomposition allows us to relate our findings to the misallocation literature on TFP losses from firm-level distortions. We find that the level of output losses and their change over time are mainly driven by scale effects rather than misallocation. We compare our method with the now standard approach which estimates the marginal revenue product of capital from value added to capital ratios (e.g. Hsieh and Klenow, 2009; Gopinath et al, 2017). The standard approach to factor market distortions generates losses that are over twice as large as the ones we identify based solely on our model of credit frictions. This may be because standard methods pick up a wider range of distortions, but it may also be because measurement errors in capital (and value added) are being erroneously attributed to misallocation. ${ }^{2}$

Our application is more than a "proof of concept"; it is an ideal case in which to study the impact of financial frictions. The financial sector is a relatively large part of the UK economy, but there are long-standing concerns that it does not serve the domestic non-financial sector well (e.g. Kay, 2012; Besley and Van Reenen, 2013). This came into sharp relief following the financial crisis, and GDP per hour worked only recovered to its pre-crisis levels in $2017 .{ }^{3}$ We show that credit frictions based on the default probability mea-

\footnotetext{
${ }^{2}$ See Rotemberg and White (2017); Bils, Klenow and Ruane (2017) and de Loecker and Collard-Wexler (2016) for recent evidence on the huge amount of capital mismeasuremt in micro data.

${ }^{3}$ In 2017 the UK's official fiscal watchdog, the Office of Budget Responsibility (2017)
} 
sures were particularly acute at the height of the financial crisis, accounting for over half of the productivity fall between 2008 and 2009. Furthermore, although conditions reverted to pre-crisis levels for large firms, credit frictions persisted for small firms and still accounted for around $20 \%$ of the difference between actual productivity and its pre-crisis trend by the end of 2013 .

The remainder of the paper is organized as follows. In the next section, we discuss some related literature. Section 3 presents a conceptual framework which models credit market imperfections as endogenous default risk, i.e. endogenous repayment probabilities. We show how default risk induces heterogeneity in the price of capital across firms, establishing a link between a firm's repayment probability and the level of its capital stock. We embed this framework in a model with heterogeneous firms and derive empirical implications at the firm-level and for the aggregate economy. In particular, we construct an aggregate measure of credit market frictions which we decompose into a scale and a TFP component. Section 4 discusses our data and measurement issues. Section 5 presents our core results. We validate the use of repayment probabilities by looking at their correlations with a range of firm outcomes and then apply the theory to measure the effects of credit frictions on aggregate output, and decompose these effects into a scale and a TFP component. Section 6 discusses several additional results looking at heterogeneity across firm size classes and sectors; comparing our method to the standard approach; incorporating labor market frictions as well as other robustness tests. Section 7 offers some concluding thoughts. Online Appendix A gives further details of the data, Appendix B contains more technical econometric details and Appendix $\mathrm{C}$ details productivity trends.

\section{Related Literature}

Our contribution relates to a large and growing literature on the aggregate consequences of firm-level distortions which shows how firm-specific distortions to output or input prices can lead to sizable decreases in aggregate output and measured TFP by distorting the allocation of inputs (and hence the size of firms). ${ }^{4}$ Few contributions in the literature have direct measures

\footnotetext{
downgraded its assumptions on underlying productivity growth citing the impact of the financial crisis.

${ }^{4}$ In addition to Hsieh and Klenow (2009, 2014), see among others Asker et al (2014), Foster, Haltiwanger and Krizan (2002), Restuccia and Rogerson (2008), Bartelsman, Halti-
} 
of the distortions that can result from a range of factors, including policyinduced frictions such as labor market regulation or preferential interest rates to state-owned firms. Hence, it is difficult to relate the empirical findings to specific mechanisms. ${ }^{5}$

There is a large theoretical literature on credit market distortions due to adverse selection, moral hazard or costly enforcement. The classic paper by Stiglitz and Weiss (1981) focused on adverse selection as the main distortion where a lender cannot observe the riskiness of a borrower. Credit is priced for the average default risk with some borrowers consequently limited in what they can borrow. The dominant approach in the macro-economic literature on credit market distortions focuses on frictions due to ex-post moral hazard where the lender has limited capacity to enforce repayment. This is used, for example, by Buera and Shin (2013) and Midrigan and Xu (2014). These models do not have any default in equilibrium. In contrast, Bernanke and Gertler (1989) and Cooley and Quadrini (2001) use a model where the financial friction is created by auditing costs which make it costly for lenders to observe firm-level shocks. The approach taken here follows models of moral hazard in the credit market such as Innes (1990), Holmstrom and Tirole (1997) and Besley et al (2012) where unobserved effort implies that increased indebtedness reduces the prospect of loan repayment. All these theoretical approaches share in common a role for collateral in increasing the efficiency of the credit market. Hence a negative shock to asset prices will tend to lead to tighter financial market conditions.

By trying to isolate the distortions from credit frictions, our paper is related to recent contributions that have examined the role of financial constraints. ${ }^{6}$ In those papers, financial constraints have an impact on capital accumulation and the allocation of capital across firms. However, the dominant paradigm used to model such frictions does not allow for default which is our key empirical measure. The quantitative assessment of output losses varies across papers but the overall conclusion appears to be that although

wanger and Scarpetta (2013), Gopinath et al (2017). Disney et al (2003) look at UK manufacturing. For a GE treatment in the time series dimension see Baqaee and Fahri (2017).

${ }^{5}$ The approach taken here is similar to that of Besley and Mueller (2018) who study the output losses due to weak law enforcement.

${ }^{6}$ For example, Jeong and Townsend (2007), Amaral and Quintin (2010), Buera and Shin (2013), Caselli and Gennaioli (2013), Midrigan and Xu (2014), Moll (2014) and Catherine et al (2018). 
financial constraints induce misallocation, the magnitude is not large (see Hopenhayn, 2014, for a review). Our finding that the losses from credit frictions are not primarily due to misallocation across heterogeneous firms is consistent with this literature.

Although we have a model of credit market frictions that incorporates default directly, our approach has less rich dynamics than some of these papers. It has parallels with Gilchrist, Sim, and Zakrajsek (2013) where distortions are embodied in firm-specific borrowing costs. The authors measure these for a subset of large U.S. manufacturing firms using the interest rate spreads on their outstanding publicly-traded debt. While borrowing costs are also firm-specific in our analysis, it is the firm's probability of default which is key as capital allocation adjusts to equate the marginal product of capital to a risk-adjusted cost of lending to a particular firm. In addition, our measure of credit frictions can be estimated for the entire economy, including firms that do not issue publicly-traded debt. An advantage of our approach is that it can be implemented with only basic information on firm size and PDs, which makes it parsimonious and scalable in a wide number of environments where data is limited.

Our paper is also related to the large literature that focuses on the macroeconomic effects of financial crises (e.g. Reinhart and Rogoff, 2011). However, many authors remain skeptical about the role of financial mechanisms in explaining persistently low productivity after the Great Recession (e.g. Byrne et al, 2016; Brynjolfsson et al, 2017). Several recent micro-studies examine the role of the Great Recession in depressing productivity. Garcia-Macia (2017), de Ridder (2017), Garicano and Steinwender (2016) and Aghion et al $(2012,2014)$ stress the role played by the cut-back in productivity-enhancing investments (such as R\&D). Some papers analyze the employment and investment effects of credit shocks using firm-level bank-lender relations, such as pre-crisis connections with Lehman Brothers in the U.S. (Chodorow-Reich, 2014), Commerzbank in Germany (Huber, 2018) and Lloyds/RBS in the UK (Anderson, Riley and Young, 2019). ${ }^{7}$ We discuss how these reduced-form approaches can be combined with our more theory-based approach in the conclusions.

\footnotetext{
${ }^{7}$ See also Acharya et al (2015), Amiti and Weinstein (2018), Bentolila et al (2018), Greenstone et al (2014) and Manaresi and Pierri (2019). Kwaja and Mian (2008) show that the performnance of firms in Pakistan suffers if they are connected to a bank subject to exogenous negative liquidity shocks (caused by nuclear testing). Like us, they find the predominant harm is to smaller firms.
} 
More broadly, our paper relates to the vast literature on financial constraints and investment. Like these contributions, we find evidence of important financial frictions. Several papers seem to show causal impacts Lamont (1997) finds that reductions in oil prices lead non-oil subsidiaries of oil companies to reduce capital expenditures. Rauh (2006) exploits nonlinear funding rules for defined benefit pension plans and Chaney et al (2012) and Gan (2007) use variation in housing price shocks to show that financial collateral shocks increase investment. ${ }^{8}$ However, as is the case with the firm-bank relationship literature, it is difficult to translate these reduced-form effects into a quantitative macro-economic assessment of output loss. This is what our paper attempts to do. A drawback of our approach is that it does not directly isolate the impact of a financial shock (although we do discuss how one could do that in the context of our approach). Rather, our methodology quantifies how the output effect of any shock (financial, demand or otherwise) is magnified in an economy subject to credit frictions relative to a benchmark economy where such frictions are absent.

\section{Conceptual Framework}

The simple model that we develop is based on Besley et al (2012), and is used to show that endogenously-determined default probabilties are a sufficient statistic for firm-level credit market frictions. In the framework, lenders offer loans to heterogenous firms whose balance sheets affect access to collateral.

\subsection{Basics}

Firms Firms produce using labor and capital and vary in their productivity, $\theta$, with production function:

$$
Y=\theta\left(L^{1-\alpha} K^{\alpha}\right)^{\eta}
$$

\footnotetext{
${ }^{8}$ Bond and Van Reenen (2007) surveyed the early empirical literature. Since then there have been important contributions by inter alia Banerjee and Duflo (2014), Benmelech et al (2008), Benmelech et al (2019), Faulkender and Petersen (2012), Lemmon and Roberts (2010), Zia (2008) and Zwick and Mahon (2017).
} 
with $0<\eta<1 .{ }^{9}$ The variable $\theta$ could capture productivity in the conventional way but we can also think of firm-specific demand shocks being captured by variation in $\theta \cdot{ }^{10}$ Given a wage of $w$, the associated conditional profit function is:

$$
\Pi(\theta, w, K)=[1-(1-\alpha) \eta] \theta^{\left(\frac{1}{1-(1-\alpha) \eta}\right)}\left[\frac{w}{(1-\alpha) \eta}\right]^{\frac{-(1-\alpha) \eta}{1-(1-\alpha) \eta}} K^{\left(\frac{\alpha \eta}{1-(1-\alpha) \eta}\right)}
$$

with profit net of depreciation being denoted as:

$$
\pi(\theta, w, \delta, K)=\Pi(\theta, w, K)-\delta K
$$

where $\delta \in(0,1)$ is the depreciation rate.

Firms also have assets $A$ which can be pledged as collateral as well as being used productively. Let $\phi \in[0,1]$ denote whether the firm produces successfully and hence is able to repay any loan it has received. Since loans are committed before uncertainty is realized, this is also the repayment probability. The probability of default is $(1-\phi)$. We suppose that the firm forfeits its assets $A$ in the event of default. The repayment probability depends on costly managerial effort where the cost function $c(\phi)$ is increasing and convex.

Banks Banks offer loans to a firm tailored to its productivity and assets. We assume that the choice of actions affecting $\phi$ are not contractible and hence that there is a potential moral hazard problem. A credit contract is a pair $\{B, R\}$ comprising the amount borrowed, $B$, and an amount to repay, $R$. Hence $(R-B) / B$ is the interest rate. Since assets can also be used productively, a firm's capital stock is $K=A+B$. Lenders can access funds from depositors or the interbank market at rate $\rho<1$. A bank's expected profit if it lends to a firm with assets $A$ and repayment probability $\phi$ is:

$$
\phi[R-\rho B]-(1-\phi)[B(1+\rho)-A] .
$$

\footnotetext{
${ }^{9}$ This is essentially a Lucas (1978) span of control model where the source of decreasing returns is on the production side and is linked to limits to managerial time. Hopenhayn (2014) and Hsieh and Klenow (2009) show that this is equivalent to a model with monopolistic competition where

$$
\eta=1-\frac{1}{\varepsilon}
$$

and $\varepsilon$ is the elasticity of demand.

${ }^{10}$ For example, different idiosyncratic quality levels as in Foster, Haltiwanger and Syverson (2008).
} 
Hence with probability $\phi$, the bank is repaid and receives $R$ while with probability $(1-\phi)$ the bank seizes the firm's collateral. ${ }^{11}$

\subsection{Lending Contracts}

Each firm faces an outside option $U(\theta, A)$ which reflects what is available to the firm in the market place. Many lending relationships are relationship specific and hence there could be a premium from staying with an existing lender which we think of as a "switching cost" which limits competition in the market. We will suppose that initially each firm is "assigned" to a lender who offers terms relative to a fixed outside option. Below, we discuss how the outside option can be made endogenous. The timing is as follows:

1. Nature assigns each firm to a bank.

2. Banks offer credit contracts $\{B, R\}$ given an outside option $U(\theta, A)$.

3. The firm chooses $\phi$.

4. Default occurs with probability $(1-\phi)$, in which case the firm loses $A$.

5. If there is no default, firms make labor hiring decisions, produce, and repay their loans.

We solve the model backwards. For simplicity, we focus on the case where the outside option of the firm always binds. ${ }^{12}$

Optimal $\phi$ (stage 3) The optimal effort (repayment probability) maximizes the expected profits of the firm given any credit contract $\{R, B\}$ that they are offered, i.e.

$$
\phi[\pi(\theta, w, \delta, A+B)-R]-(1-\phi) A-c(\phi) .
$$

The first order condition for optimal effort implies:

$$
c^{\prime}(\phi)=\pi(\theta, w, \delta, K)-R+A .
$$

Throughout we will assume interior solutions. The optimal repayment rate is increasing in profit and assets but decreasing in the interest payment.

\footnotetext{
${ }^{11}$ It would be straightforward, at the cost of greater notational complexity, to allow for only some assets in a firm's balance sheet to be used as collateral.

${ }^{12}$ See Besley et al (2012) for an exploration of the case where this is not true.
} 
Optimal Contracts (stage 2) The optimal credit contract solves

$$
\operatorname{Max}_{\{B, R\}} \phi[R-\rho B]-(1-\phi)[B(1+\rho)-A]
$$

subject to the participation constraint (outside option)

$$
\phi[\pi(\theta, w, \delta, A+B)-R]-(1-\phi) A-c(\phi) \geq U(A, \theta)
$$

and equation (6) for optimal effort. The optimal allocation of capital, assuming that the participation constraint is binding and an interior solution with $\hat{B}(A, \theta)>0$, solves: ${ }^{13}$

$$
\Pi_{K}(\theta, w, A+\hat{B}(A, \theta))=\frac{\delta+\rho}{\hat{\tau}(\delta, \rho, \hat{\phi}(A, \theta))}
$$

where $\hat{\phi}(A, \theta)$ is the repayment probability of a firm with assets $A$ and productivity $\theta$ with the optimum credit contract and

$$
\hat{\tau}(\delta, \rho, \hat{\phi}(A, \theta))=\frac{1}{1+\frac{(1+\rho)(1-\hat{\phi}(A, \theta))}{(\delta+\rho) \hat{\phi}(A, \theta)}}<1
$$

denotes the capital market distortion which raises the cost of capital above $(\delta+\rho)$. Note that $\hat{\tau}(\delta, \rho, \hat{\phi}(A, \theta))$ is increasing in $\hat{\phi}(A, \theta)$, i.e., a higher

\footnotetext{
${ }^{13}$ To derive this, note that the binding outside option and equation (6) imply that
}

$$
\phi c^{\prime}(\phi)-c(\phi)=U(A, \theta)+A
$$

which implicitly defines $\hat{\phi}(A, \theta)=g(U(A, \theta)+A)$ where $g(\cdot)$ is an increasing function since $\phi(\cdot)$ is convex. Substituting this into the participation constraint implies that the repayment rate is given by

$$
R=\pi(\theta, w, \delta, A+B)-\frac{(1-\hat{\phi}(A, \theta)) A+c(\hat{\phi}(A, \theta))+U(A, \theta)}{\hat{\phi}(A, \theta)}
$$

Plugging this into the bank's profit function delivers an expression in $B$ :

$\hat{\phi}(A, \theta)\left(\pi(\theta, w, \delta, A+B)-\frac{(1-\hat{\phi}(A, \theta)) A+c(\hat{\phi}(A, \theta))+U(A, \theta)}{\hat{\phi}(A, \theta)}-\rho B\right)+(1-\hat{\phi})(A-(1+\rho) B)$

The result follows by maximizing (10) with respect to $B$. 
repayment probability implies that the capital market distortion is lower. Moreover, (12) illustrates how an empirical measure of $\hat{\phi}(A, \theta)$ is a sufficient statistic for credit market frictions, all else equal.

Equation (11) is the core equation for the allocation of capital and provides a direct link between estimates of firm-level repayment probabilities and factor allocations. It says that the firm's marginal product of capital is set equal to the risk-adjusted sum of the depreciation rate and the lender's cost of funds. ${ }^{14}$

To get a feel for what equation (12) implies quantitatively, suppose that a firm has a $90 \%$ repayment probability and that $\rho=\delta=0.05$ so that the marginal product of capital in the absence of default would be $10 \%$. With an optimal credit contract, the marginal product of capital would be approximately $22 \%$, which is around double the riskless case. Even with a repayment probability of $95 \%$, the marginal product of capital would be around $16 \%$.

The Outside Option Closing the model requires us to determine the outside option $U(A, \theta)$ endogenously. To do this, we adopt a simple approach which permits us to think about how market conditions can matter. Specifically, we postulate a switching cost, $\kappa$, incurred if a firm moves to an alternative bank. So if $\kappa=0$, switching is costless. Let $\hat{P}(A, \theta: U)$ be the maximized level of the bank's profit with an outside option $U,{ }^{15}$ and define $\hat{U}(A, \theta)$ from $\hat{P}(A, \theta: \hat{U}(A, \theta))=0$, as the value of the outside option which generates zero profits for an alternative bank. This defines the best possible terms that another bank would be willing to offer in order to attract a firm. We then suppose that the equilibrium outside option will be $U(\theta, A)=\hat{U}(A, \theta)-\kappa$, i.e., the firm earns a discount on its best outside

\footnotetext{
${ }^{14}$ To make this explicit, use equation (12) to rewrite the right hand side of equation (11) as

$$
\delta+\rho+\tilde{\rho}(A, \theta)
$$

where $\tilde{\rho}(A, \theta)=(1+\rho)\left[\frac{1-\hat{\phi}(A, \theta)}{\hat{\phi}(A, \theta)}\right]$ is an endogenously-determined firm-specific credit spread similar to Gilchrist, Sim, and Zakrajsek (2013), which is decreasing in the repayment probability.

${ }^{15}$ This is given by:

$$
\pi^{*}(A, \theta: U)=\max _{B \geq 0}(f(g(U+A))[g(U+A)+\Pi(\theta, w, A+B)]+A-\rho B)
$$
}


option equal to the switching cost. If there is greater reluctance by lenders to take on new clients, modeled as an increase in the switching cost, it will reduce $U(A, \theta)$. This lowers the firm's profit. However, it also has a "real" effect in our second best model since worsening the outside option reduces the repayment probability and hence reduces the amount of capital that any borrower is allocated.

\subsection{Firm-Level Implications}

Let $N_{t}$ be the population of firms active at date $t$ with characteristics $\left\{\theta_{n t}, A_{n t}\right\}_{n=1}^{N_{t}}$. The production function of firm $n$ at time $t$ is:

$$
Y_{n t}=\theta_{n t}\left(L_{n t}^{1-\alpha} K_{n t}^{\alpha}\right)^{\eta}
$$

Credit frictions are modeled as firm-specific capital input prices, determined by each firm's repayment probability. Although our focus is on credit frictions, we allow for the possibility of labor market frictions modeled as firmspecific labor input prices. Since output prices are normalized to 1, we can write the firm's profit as

$$
Y_{n t}-\left(\frac{w_{t}}{\tau_{n t}^{L}}\right) L_{n t}-\left(\frac{\rho+\delta}{\tau_{n t}^{K}}\right) K_{n t}
$$

where $w_{t}$ is the wage and $(\rho+\delta)$ is the cost of capital, both of which are common to all firms, and $\left\{\tau_{n t}^{L}, \tau_{n t}^{K}\right\}$ are firm-specific factors affecting labor and capital input prices. Equation (12) implies that $\tau_{n t}^{K}=\hat{\tau}\left(\delta, \rho, \hat{\phi}\left(A_{n t}, \theta_{n t}\right)\right)$, i.e. a firm $n$ faces a price of capital which depends upon its repayment probability. In general, lower values of $\tau_{n t}^{L}$ or $\tau_{n t}^{K}$ represent more distorted factor markets. ${ }^{16}$

Deriving optimal factor demands, the output level of firm $n$ at date $t$ with distortions $\left\{\tau_{n t}^{L}, \tau_{n t}^{K}\right\}$ is

$$
Y_{n t}=\theta_{n t}^{\frac{1}{1-\eta}} \psi\left(w_{t}, \rho+\delta\right) \tau_{n t}
$$

where

$$
\tau_{n t} \equiv\left(\tau_{n t}^{L}\right)^{\frac{(1-\alpha) \eta}{1-\eta}}\left(\tau_{n t}^{K}\right)^{\frac{\alpha \eta}{1-\eta}}
$$

\footnotetext{
${ }^{16}$ Allowing a more general set of distortions in this way will allow us to compare the results to the literature on misallocation.
} 
summarizes firm-specific distortions in labor and capital markets, and $\psi\left(w_{t}, \rho+\delta\right) \equiv$ $\left(\frac{(1-\alpha) \eta}{w_{t}}\right)^{\frac{(1-\alpha) \eta}{1-\eta}}\left(\frac{\alpha \eta}{\rho+\delta}\right)^{\frac{\alpha \eta}{1-\eta}}$.

The frictionless case is defined as a world where all firms face the same input prices; in other words $\tau_{n t}^{L}=\tau_{n t}^{K}=1$ for all firms $n=1, \ldots, N$. In this benchmark case, the output of a firm is determined solely by its fundamental productivity $\theta_{n t}$, the technological parameters $\alpha, \eta$ and $\delta$, and the frictionless factor prices $\left\{w_{t}, \rho\right\}$.

\subsection{Aggregate Implications}

Aggregate Losses from Factor Market Frictions Summing across firms, aggregate output is:

$$
Y_{t}=\sum_{n=1}^{N} Y_{n t}=\psi\left(w_{t}, \rho_{t}+\delta\right)\left(\sum_{n=1}^{N} \theta_{n t}^{\frac{1}{1-\eta}}\right) \Theta_{t}
$$

where

$$
\Theta_{t}=\sum_{n=1}^{N} \omega_{n t} \tau_{n t}
$$

is a weighted average of firm-level factor market distortions, with productivity "weights" $\omega_{n t}=\theta_{n t}^{\frac{1}{1-\eta}} / \sum_{n=1}^{N} \theta_{n t}^{\frac{1}{1-\eta}}$.

Suppose that $\rho$ is determined in global capital markets while the aggregate wage, $w_{t}$, is determined endogenously. With an exogenously fixed labor endowment $L$, the equilibrium real wage solves

$$
w_{t}=\frac{(1-\alpha) \eta \psi\left(w_{t}, \rho+\delta\right)\left(\sum_{n=1}^{N} \theta_{n t}^{\frac{1}{1-\eta}}\right) \Theta_{t}}{L}
$$

which depends on aggregate distortions through $\Theta_{t}$.

This framework allows us to derive a counter-factual level of output, $\hat{Y}_{t}$, associated with a chosen reference level of distortions $\left\{\hat{\tau}_{n t}^{K}, \hat{\tau}_{n t}^{L}\right\}$ and an associated "reference efficiency level" $\hat{\Theta}_{t}$. A special case is the frictionless benchmark where $\hat{\tau}_{n t}^{K}=\hat{\tau}(\delta, \rho, 1)=\hat{\tau}_{n t}^{L}=1$ for all firms at each $t$. In this benchmark, there is no credit market default and labor markets equalize the marginal product of labor across firms. However, other reference levels are 
possible, e.g. the outcome prior to a financial crisis or the level of distortions observed in another economy.

For any chosen reference level, the deviation of actual output from its reference level is given by

$$
\frac{\hat{Y}_{t}-Y_{t}}{\hat{Y}_{t}}=1-\left[\frac{\Theta_{t}}{\hat{\Theta}_{t}}\right]^{\frac{1-\eta}{1-\alpha \eta}} .
$$

So $\Theta_{t} \leq \hat{\Theta}_{t}$ is a sufficient statistic for the output loss due to factor market distortions. Below, we will calculate output losses using equation (20) with data on firm-level repayment probabilities and employment.

Scale and TFP effects The framework enables us to decompose the total effect of frictions on output into a "scale" and "TFP" effect by writing:

$$
\Theta_{t}=\Theta_{t}^{S} \Theta_{t}^{T}
$$

where

$$
\Theta_{t}^{S} \equiv\left(\sum_{n=1}^{N} \omega_{n t} \tau_{n t} \tau_{n t}^{L}\right)^{(1-\alpha) \eta}\left(\sum_{n=1}^{N} \omega_{n t} \tau_{n t} \tau_{n t}^{K}\right)^{\alpha \eta}
$$

and

$$
\Theta_{t}^{T} \equiv \frac{\sum_{n=1}^{N} \omega_{n t} \tau_{n t}}{\left(\sum_{n=1}^{N} \omega_{n t} \tau_{n t} \tau_{n t}^{L}\right)^{(1-\alpha) \eta}\left(\sum_{n=1}^{N} \omega_{n t} \tau_{n t} \tau_{n t}^{K}\right)^{\alpha \eta}} .
$$

The scale effect, $\Theta_{t}^{S}$, represents the impact of frictions on output through the size of the aggregate capital stock and labor inputs, while holding the joint distribution of frictions and productivity constant, while the TFP effect estimates the impact of frictions on output holding the aggregate stock of capital and labor inputs fixed. This decomposition allows us to relate our findings to the standard misallocation literature which focuses mainly on the measurement of TFP losses due to firm-level distortions (e.g. Hsieh and Klenow, 2009). Below, we will estimate both of these terms separately.

Since the scale and TFP components of $\Theta$ are multiplicative, we can write the total output loss due to credit market frictions as

$\frac{1-\eta}{1-\alpha \eta}\left(\ln \left(\hat{\Theta}_{t}\right)-\ln \left(\Theta_{t}\right)\right)=\frac{1-\eta}{1-\alpha \eta}\left(\ln \left(\hat{\Theta}_{t}^{S}\right)-\ln \left(\Theta_{t}^{S}\right)\right)+\frac{1-\eta}{1-\alpha \eta}\left(\ln \left(\hat{\Theta}_{t}^{T}\right)-\ln \left(\Theta_{t}^{T}\right)\right)$ 
where $\Theta_{t}, \Theta_{t}^{S}$, and $\Theta_{t}^{T}$ are the actual estimates and $\hat{\Theta}_{t}, \hat{\Theta}_{t}^{S}$, and $\hat{\Theta}_{t}^{T}$ are the counterfactual benchmarks. The percentage contribution to output losses of scale and TFP distortions can be written as $\left(\frac{\ln \left(\hat{\Theta}_{t}^{S}\right)-\ln \left(\Theta_{t}^{S}\right)}{\ln \left(\hat{\Theta}_{t}\right)-\ln \left(\Theta_{t}\right)}\right) * 100$ and $\left(\frac{\ln \left(\hat{\Theta}_{t}^{T}\right)-\ln \left(\Theta_{t}^{T}\right)}{\ln \left(\hat{\Theta}_{t}\right)-\ln \left(\Theta_{t}\right)}\right) * 100$, which is what we report below.

\section{Data and Measurement}

In this section, we describe our data sources and show how the magnitudes suggested by the model can be measured empirically. More details on the construction of the data can be found in online Appendices A and B, but we sketch the most salient information here.

\subsection{Administrative Data on Firm Size}

Our main source of micro data is the Inter-Departmental Business Register (IDBR), a business register of all UK establishments (i.e. "local units" of manufacturing plants or retail stores). Our unit of analysis are firms which are collections of these establishments. We work with annual snapshots of the IDBR which are used as the sampling frame for two smaller but richer datasets, the Annual Business Inquiry and the Annual Business Survey (ABI/ABS). ${ }^{17}$ We focus on the non-financial "market sector"- i.e. dropping agriculture, mining and quarrying and utilities as well as sectors where output is particularly hard to measure - local and central government, education, health care, financial services, real estate and non-profit organizations.

In extensions we also use the $\mathrm{ABI} / \mathrm{ABS}$ which contains output, investment and (goods and services) intermediate inputs. ${ }^{18}$ The ABI/ABS surveys are a census of larger businesses and a stratified (by industry, region and employment) random sample for establishments with under 250 employees (SMEs). They are similar in structure and content to the U.S. Annual Survey of Manufacturing (ASM) except they also contain data on the non-manufacturing

\footnotetext{
${ }^{17}$ See Office for National Statistics $(2012,2018)$. Sampling weights are provided in the $\mathrm{ABI} / \mathrm{ABS}$ to make them representative.

${ }^{18}$ These surveys are used by the UK Census Bureau (the Office for National Statistics or ONS) in the construction of various national account aggregates. See Barnett et al (2014a) and Riley et al (2015) for useful discussions of these datasets and recent work on productivity using them. Details of the ABI and ABS data can also be found in Griffith (1999) and Bovill (2012) respectively.
} 
sectors (and unlike the U.S. Economic Census, have capital investment in non-manufacturing). Although we do not strictly require the richer data of the $\mathrm{ABI} / \mathrm{ABS}$ to implement our method, the sample is necessary to compare our approach with the standard approach in the misallocation literature (e.g. Hsieh and Klenow, 2009).

Table 1 shows some basic descriptive statistics. In the IDBR there are an annual average of 15.7 million employees in the market sector across 1.5 million firms. Using the ONS definition of SMEs as having under $250 \mathrm{em}-$ ployees conveniently generates a split of about half of all employees in the SME sector (51.8\%) and half in large firms (48.2\%). Of course, there are vastly more firms in the SME sector, due to the well-known heavily skewed firm size distribution (on average only $0.37 \%$ of all firms have more than 250 employees).

\subsection{Default Probabilities and Firm Accounting Data}

A unique feature of our study is that we use data on estimates of firms' repayment probabilities $\left(\phi_{n t}\right)$. In order to estimate repayment probabilities, we use financial statement data from Bureau Van Dijk's (BvD) Orbis database in combination with S\&P's PD Model and CreditPro. PD (Probability of Default) Model is a credit scoring facility which uses a combination of financial accounts data, industry, and country-specific macroeconomic factors to assess the credit risk of a company. The scoring algorithm can be applied both to private and publicly listed firms.

PD Model has 19 firm-level accounting items to generate a risk score (called "implied credit worthiness") using S\&P's traditional rating symbols, ('triple $\mathrm{A}^{\prime}=\mathrm{AAA}$, 'triple $\mathrm{B}^{\prime}=\mathrm{BBB}$, etc.). The exact list of data inputs depends on the public/private status of the firms and the broad sector in which they operate. ${ }^{19}$ The model generates 21 bins of risk scores (from AAA to $\mathrm{C}$ ) and these are combined with historical information on default rates for each bin in each time period from S\&P CreditPro. We only use lagged information to do this, in order to reflect lenders' historical information sets.

\footnotetext{
${ }^{19}$ In addition to industry and year, the accounting items are: EBIT, income tax expense, interest expense, total revenue in the previous year, cash flow from operation, net property plant and equipment, retained earnings, total assets, cash and short-term investments, current liabilities, total debt, total liabilities, net income, earnings from continuing operations, total depreciation and amortization, total deferred taxes, and other non cash items.
} 
For example, in 2006 we use average historical default rates from 1980 to 2006, as market participants would have used. PD model does not require that a firm reports all 19 items. We generate risk scores for all publicly listed firms that report total equity and all privately listed firms that report sales (or, if not sales, the four following items: total assets, fixed assets, total liabilities and current liabilities). We run the model through 16.6 million firm-year observations in the BvD Orbis data for 2005-2013. We are able to generate a risk score for $95 \%$ of those (15.8 million observations), with the remainder likely to be essentially shell or non-trading companies.

The next step is to match the data on PDs and accounting information from Orbis to the IDBR. Orbis and the IDBR both have Company Registration Numbers and the UK Data Service performed the match. Appendix Table A2 shows that we match $54 \%$ of the IDBR data to PDs and $70 \%$ of the ABI/ABS subsample. There are several reasons for the imperfect match rate. First, some of the IDBR firms are branches of foreign multinationals rather than wholly owned subsidiaries, so will not appear in Orbis. Second, as noted above, some Orbis firms do not have the necessary inputs to calculate a PD. Third, Orbis has incomplete coverage of smaller firms (hence the better match rate with the $\mathrm{ABI} / \mathrm{ABS}$ as these are skewed towards larger firms). Fourth, the UK Data Service is not able to match all the CRNs to an enterprise unit in the IDBR.

Our baseline approach to dealing with missing PDs is to impute them in the IDBR using year and three digit industry specific regressions on employment interacted with firm age. Importantly, we show that all our results are robust to working solely with the non-imputed data or just the ABI/ABS. ${ }^{20}$ The non-imputed IDBR sample covers $74 \%$ of aggregate employment because firms with missing PDs tend to be small, which is why imputing missing PDs makes little difference to the aggregate results.

\subsection{Descriptive Statistics on Default Probabilities}

Figure 1 shows the evolution of the employment-weighted average of firmlevel probabilities of default, i.e. the aggregate default probability. In all years, default probabilities are systematically higher for SMEs - consistent

\footnotetext{
${ }^{20}$ Whenever we use smaller samples (e.g. samples without predicted PDs), we construct our own set of sampling weights in order to capture aggregate developments.
} 
with the idea that lenders regard SMEs as riskier. ${ }^{21}$ Second, the time-series patterns show that default probabilities are countercyclical, decreasing prior to the global financial crisis, rising sharply during the crisis, and falling back thereafter roughly to pre-crisis levels. This is in line with the existing literature on credit spreads (e.g. Gilchrist and Zakrajsek, 2012). There is clear heterogeneity between SMEs and large firms, however. The jump during the crisis was larger for SMEs, and unlike their larger counterparts, their default probabilities have stayed elevated through $2013 .^{22}$

The increase in default probabilities in our sample reflects the deterioration of credit conditions faced by firms during and after the financial crisis. All of the effects suggested by the model of Section 2 are likely to have been at work. First, banks' funding conditions deteriorated, represented by a increase in $\rho$, due to stress in inter-bank markets. ${ }^{23}$ Second, the valuation of commercial real estate saw a sharp decline during the crisis, which can be thought of as a fall in $A .{ }^{24}$ Third, competition in the UK banking sector was negatively affected during the crisis. Concerns about the effectiveness of competition in the retail lending market are long-standing and the financial crisis exacerbated this through mergers and exits from the market. ${ }^{25} \mathrm{In}$ 2010, concentration was higher than before the crisis in many retail banking sub-markets, including SME banking (Independent Commission on Banking, 2011).

\footnotetext{
${ }^{21}$ This is implied by our model as they have a lower value of $\theta_{n t}$ and are also likely to have weaker balance sheets, i.e lower collateral $A_{n t}$.

${ }^{22}$ Controlling for industry composition makes little difference to these results.

${ }^{23}$ The average annual CDS premium for the 6 major UK banks stood at 21 basis points in 2007 and peaked at 211 basis points in 2012 (Bank of England, 2014). The true cost of granting new loans is likely to have been even higher due to the need to repair balance sheets and adhering to stricter capital requirements.

${ }^{24}$ According to Benford and Burrows (2013), by the end of 2007 commercial real estate loans accounted for more than a third of the stock of lending to UK private non-financial companies by UK-resident banks. That the availability of pledgeable assets plays a role in affecting corporate investment is also argued, for example, in Gan (2007) and Chaney, Sraer and Thesmar (2012).

${ }^{25}$ There have been several studies on this topic since 2000: the Cruickshank report into competition in UK banking (2000), the Competition Commission's inquiry into SME Banking (2002), the Office of Fair Trading's (OFT) Survey of SME Banking (2006), the OFT's Review of Barriers to Entry, Expansion and Exit in Retail Banking (2010) and the Final Report of the Independent Commission on Banking (2011). During the crisis, the mergers of Lloyds TSB with HBOS and Santander with Alliance \& Leicester eliminated the strongest challengers identified by the OFT before the crisis.
} 
Figure 2 looks at the distribution of credit scores across firms and its change over time. ${ }^{26}$ Panel A shows the distribution for every year and Panel B overlays the last year's density with the first year. There is a clear shift in the mass to the right, from the relatively low risk scores of $\mathrm{B}$ (bin 9, average default probability of 6.5\%) towards scores of CCC+ (bin 11, average default probability of $23 \%$ ) and worse. This indicates an assessment of a larger chance of default over 2008-2013. For example, Table A1 shows that the fraction of firms in the B group fell from $36 \%$ in 2005 to $18 \%$ in 2013, whereas the fraction rose from $6 \%$ to $17 \%$ in the CCC+ group.

\subsection{Estimating Aggregate Distortions}

In this section, we describe how we estimate the aggregate distortion due to default risk corresponding to equation (18) using the micro-data. We proceed "bottom-up" by first disaggregating by industry (which we index by $j$ ) and calculating industry-specific distortions $\Theta_{j t}$. We then compute industry size-weighted aggregates of $\Theta_{t}$ to obtain a whole-economy measure.

To measure relative productivity $\left(\omega_{n j t}\right)$ at the firm level, we use firm-level employment data together with repayment probabilities. A firm's employment share in total industry employment is

$$
\gamma_{n j t}=\frac{L_{n j t}}{\sum_{n=1}^{N_{j t}} L_{n j t}}
$$

where $L_{n j t}$ denotes the employment of firm $n$ in industry $j$ at time $t$. In a frictionless world, $\omega_{n j t}=\gamma_{n j t}$, i.e. the productivity weight and employment share are the same. However, with factor market distortions:

$$
\omega_{n j t}=\frac{\gamma_{n j t} \Theta_{j t}}{\tau_{n t} \tau_{n t}^{L}} .
$$

Hence, a firm's relative productivity is estimated by adjusting its employment shares using the firm-specific friction (16) and the aggregate industry distortion measure, $\Theta_{j t}$.

In the ABI/ABS sub-sample, we can use an alternative estimate of $\omega_{n j t}$ by computing firm-level Solow residuals using data on value added, the wage

\footnotetext{
${ }^{26}$ Although S\&P's has 21 separate ratings (from AAA to C-), we group the cells from AAA to A- due to disclosure rules as cell sizes are small. For the empirical analysis we use all 21 bins.
} 
bill, and capital stock estimates. However, using Solow residuals might not be appropriate as this would deliver a measure of productivity which is contaminated by the very frictions we want to measure. In addition, there are many measurement issues with firm-level data, particularly as regards the estimation of capital stocks (e.g. De Loecker and Collard-Wexler, 2016).

Putting it all together, we proceed as follows. Let $\tilde{\gamma}_{n j t}$ be the share of firm $n$ in total employment in industry $j$ at date $t$ :

$$
\tilde{\gamma}_{n j t}=\frac{\bar{L}_{n j}}{\sum_{n=1}^{N_{j t}} \bar{L}_{n j}}
$$

where $\bar{L}_{n j}$ denotes the average employment over the entire sample period. In our baseline estimations, we ignore the possibility of labor market frictions and set $\tau_{n t}^{L}=1$. We then use our estimate of the firm-level repayment probability, $\phi_{n t}$, from PD Model and use the fact that equation (27), together with the firm's optimizing decisions implies that:

$$
\tilde{\gamma}_{n j t}=\frac{\omega_{n j t} \hat{\tau}\left(\delta, \rho_{t}, \phi_{n t}\right)^{\frac{\alpha \eta}{1-\eta}}}{\Theta_{j t}} .
$$

Each firm's relative productivity is given by:

$$
\omega_{n j t}=\tilde{\gamma}_{n j t} \Theta_{j t} \hat{\tau}\left(\delta, \rho_{t}, \phi_{n t}\right)^{-\frac{\alpha \eta}{1-\eta}} .
$$

To solve for $\omega_{n j t}$, we use the fact that $\sum_{n=1}^{N_{j t}} \omega_{n j t}=1$, which implies that $\Theta_{j t}$ can be written entirely in terms of observables as:

$$
\Theta_{j t}=\left[\sum_{n=1}^{N_{j t}} \tilde{\gamma}_{n j t} \hat{\tau}\left(\delta, \rho_{t}, \phi_{n t}\right)^{-\frac{\alpha \eta}{1-\eta}}\right]^{-1}
$$

Plugging equation (30) in equation (29) enables us to estimate relative firmlevel productivities. Note that $\Theta_{j t}$ can be estimated either using equation (30) or equation (18) using the estimates of $\omega_{n j t}$. For the estimation of the scale and TFP effects, we follow equations (22) and (23) after estimating $\omega_{n j t}$.

An advantage of our approach is that the only data requirements are data on firm-level employment and repayment probabilities. As our last step, we 
use industry employment shares to obtain an estimate of $\Theta_{t}$. Specifically, we write our estimate of the efficiency parameter with distortions as

$$
\tilde{\Theta}_{t}=\sum_{j=1}^{J} \chi_{j t} \Theta_{j t}
$$

where $\chi_{j t}$ is industry $j$ 's share of aggregate market sector employment at time $t$.

Note that we work with average employment in equation (27), rather than time-varying employment. This implies that time-variation in $\omega_{n j t}$ only comes from changes in the population of firms in each industry. In other words, we fix a firm's "fundamental" productivity when considering changes in default risk. This minimizes the possibility that our estimates of $\Theta_{j t}$ reflect demand-side shocks, except to the extent that these change the level of perceived default risk. ${ }^{27}$

Finally, we have to specify three parameter values for the baseline estimates. For the degree of returns to scale, we assume $\eta=0.85,{ }^{28}$ for the output-capital elasticity we use $\alpha=1 / 3$ and we also set $\rho=\delta=0.05$ (as in e.g. Hsieh and Klenow, 2009). In Section 6, we discuss the sensitivity and robustness of our baseline results to a wide number of alternative parameter values.

\section{Core Results}

We look at the evidence in two steps. We begin by looking at the firm-level implications of credit market frictions. Specifically, we investigate whether the repayment probabilities correlate with firm-level behavior as suggested by the theory in Section 3.3. This is a validation exercise. We then use the data to examine the aggregate effects of credit frictions following Section 3.4.

\footnotetext{
${ }^{27}$ There are other ways to estimate $\omega_{n j t}$ using employment data. First, we could rely solely on lagged employment ( $t-1$ and earlier), but this would mean that we would be unable to calculate $\omega_{n j t}$ for entrants at time $t$. Second, we could rely solely on current employment (or current and lagged employment). Results seemed reasonably stable across different methods.

${ }^{28}$ This is a standard value - see the survey in Garicano, Lelarge and Van Reenen (2016) for example.
} 


\subsection{Firm-level Outcomes}

One validation of our approach is to examine whether there are robust correlations between the repayment probabilities and firm-level decisions as predicted by our theory in Section 3.3. In the IDBR sample, we can look at the relationship between the predicted repayment probability and employment (and also survival). For the smaller ABI/ABS sample, we have a richer set of dependent variables including data on value added, investment (capital expenditures), and an estimate of the size of the capital stock. From Orbis, we use measures of total assets and fixed assets for the firms in the ABI/ABS sample.

We estimate the following empirical model for firm $n$ in industry $j$ in year $t$ :

$$
\ln \left(y_{n j t}\right)=\beta \ln \tilde{\phi}\left(x_{n j, t-1}\right)+a_{n}+a_{t}+\varepsilon_{n j t} .
$$

where $y_{n j t}$ is the performance outcome; $\tilde{\phi}\left(x_{n j, t-1}\right)$ is the predicted repayment probability derived from the PD model. We make explicit that this is derived from information dated at $t-1$ which we denote by $x_{n j, t-1} ; a_{n}$ are either industry fixed effects or industry and firm fixed-effects; $a_{t}$ are year dummies; and $\varepsilon_{n j t}$ is an error term clustered by firm.

We estimate equation (32) in Table 2, with Panel A controlling for industry fixed effects and Panel B controlling for industry and firm fixed effects (both panels have time dummies). The firm fixed effects specification controls for all sources of persistent firm-level heterogeneity, and hence is quite demanding: the relationship between performance and the repayment probability is identified only from variation in $\phi_{n j t}$ and performance within firms over time.

In the first two columns of Table 2, we use employment as the dependent variable, for the whole IDBR in column (1) and the ABI/ABS subsample in column (2). Employment is positively and significantly correlated with the repayment probability in all specifications, but with a much smaller coefficient when firm fixed effects are included, suggesting that a substantial part of the relationship is driven by unobserved firm heterogeneity. For example, a $10 \%$ increase in the repayment probability is associated with a $0.3 \%$ increase in employment in column (2) of Panel B. For columns (3) to (10), there is a consistent positive correlation between the expected repayment probability and all the firm-level performance outcomes: value added, capital, and investment. Consistent with the theory, the coefficient on a firm's repayment probability is larger for capital and investment than for labor 
(as shown explicitly in columns (8) and (9)). Column (11) indicates that a higher repayment probability is also associated with a higher probability of survival. ${ }^{29}$ Table 2 is also robust to the inclusion of industry-year fixed effects. $^{30}$

Overall, these results suggest that default risk is a promising way of looking at credit market conditions at the firm level. The findings are consistent with a model in which the repayment probability is an input into the firm's cost of capital and where firms with high default probabilities have less access to capital, reducing their size for a given level of productivity. It is particularly encouraging for the approach that we take that the default probability predicts firm-level outcomes in the presence of firm fixed effects; especially so when the firm-level outcomes are sourced from an entirely different dataset than the one we use to estimate those default probabilities with the S\&P software.

\subsection{Aggregate Outcomes}

We now turn to the analysis of the macroeconomic effects of credit frictions by computing estimates of $\Theta_{t}$ and the associated output losses. This will give an insight into how important default risk is in affecting the economy through reducing the stock of capital and distorting its allocation across firms.

Our baseline estimates of credit frictions, $\Theta_{t}$, are in Table 3. These are based on the population IDBR data with sample sizes in Column (1). The estimates of firm-level relative productivities obtained using equation (29) rely solely on data on employment and probabilities of repayment. For the moment, we set aside entirely the possibility of labor market frictions, setting $\tau_{n t}^{L}=1$. Column (2) is the core estimate of $\Theta_{t}$ using equation (18) and Column (3) gives our estimates of the associated output losses according

\footnotetext{
${ }^{29}$ Survival is defined as the exit of the firm from the economy: an extreme event. The default risk estimated with PD Model captures a swathe of default events, bankruptcy being only one of them (which is one reason why the coefficient is not unity). In a fully dynamic model with renegotiation and bankruptcy costs, it is possible that firms could reschedule their debts rather than disappearing completely upon default.

${ }^{30}$ The number of observations varies across the two panels of Table 2 because singleton observations are dropped when we include firm fixed effects. The number of observations differs across columns even within the ABI/ABS sample because we condition on nonmissing and strictly positive values of the dependent variable (in order to take logs). Table A3 shows that the results are robust to conditioning on the same sample across columns.
} 
to equation (20). We compare the actual state of the economy to a world without default where $\phi_{n t}=1$ for all $n, t$. Columns (2) and (3) show that credit frictions depress aggregate output by between $26 \%$ and $29 \%$ every year in our sample period. The average annual output loss over 2005-2013 is about $27.5 \%$. An alternative way of describing these results is to say that productivity (and real wages) would rise by $38 \%(=27.5 /(1-27.5))$ if credit frictions were eliminated. Either way, these results represent nontrivial effects on output.

Table 3 also gives some insight into how aggregate credit frictions vary over time. Using equation (19) it is clear that the change in output (equivalent to labor productivity) that can be explained by changes in credit market frictions is given by the change in logs of Column (2) as follows:

$$
\Delta \ln \left(\frac{Y}{L}\right)_{t}=\frac{1-\eta}{1-\alpha \eta}\left[\ln \Theta_{t}-\ln \Theta_{t-1}\right]
$$

Column (4) estimates this implied change in productivity due to changes in credit frictions. Note that unlike Columns (2) and (3) this does not rely on a comparison with an idealized benchmark. It is clear that the aggregate impact of credit frictions deteriorated markedly in the Great Recession and this mirrors the time path of default assessments from the PD Model in Figure 1. We estimate that in 2009, a worsening of credit frictions caused a $4.8 \%$ loss of output. The actual fall of labor productivity between 2009 and 2008 was $9.3 \%$ (see Appendix C, especially Figure A1), implying that credit frictions account for just over half (4.8/9.3) of the productivity slump in the Great Recession. ${ }^{31}$ Clearly this leaves room for many other factors, such as demand shocks, as potentially important (e.g. Mian and Sufi, 2018) as well as other finance-driven mechanisms, which is something we return to in the conclusions.

In Columns (5) through (8) of Table 3, we decompose the effect of aggregate credit frictions into scale and TFP components using equations (22) and (23). Column (5) shows our estimates of scale efficiency, $\Theta_{t}^{S}$, and Column (6) shows the corresponding percentage output loss due to credit frictions. Column (7) shows our estimates of TFP efficiency, $\Theta_{t}^{T}$, and Column (8) shows

\footnotetext{
${ }^{31}$ Further, as discussed in Appendix C, the model implies that we explain about a fifth of the UK productivity gap by 2013: the difference between the level of productivity at the end of the sample period and what we would have predicted from the 1979-2007 annual growth trend of output per worker.
} 
the corresponding percentage output loss due to credit frictions. The results indicate that the scale effects dominate quantitatively: on average, scale effects account for about $93 \%(=25.5 / 27.5)$ of the overall output losses. For example, in 2009, the peak of the credit crisis, the $29.1 \%$ total loss divides into $27.0 \%$ from scale losses and $2.1 \%$ from TFP losses. Thus it is the aggregate deterioration in default risk assessments which drives the output losses from credit market frictions, rather than the way in which default probabilities are distributed across firms with different productivity levels. This is consistent with the sharp decline in capital investment following the financial crisis (see Appendix Figure A2). Our results are robust to using the ABI/ABS datasets. Appendix Table A4 indeed shows that in the entire ABI/ABS the estimated overall loss is $27.4 \%$, almost identical to that in the IDBR in Table $3 .{ }^{32}$

\section{Additional Results}

In this section, we present some further results, both to provide further insights into the patterns observed in the data and to contrast our results with other ways of measuring the impact of credit market distortions. We also report the results from a series of robustness checks.

\subsection{Heterogeneity Between Firm Sizes and Industry Segments}

We have already seen from Figure 1 that there are substantial differences in the default probabilities of large and small firms, including how they have evolved since the financial crisis. Since our estimates are computed from micro data, they can be disaggregated between small and large firms. A priori, we would expect small firms to face a much more challenging environment in accessing credit, as reflected in their higher default assessments by lenders.

To explore this empirically, Table 4 disaggregates $\Theta_{t}$ into two sub-groups reflecting firm size (we use a threshold of 250 employees). We maintain the

\footnotetext{
${ }^{32}$ The findings in Table 3 are also in line with the results of Gilchrist, Sim, and Zakrajsek (2013) and Midrigan and Xu (2014) who find modest TFP losses from misallocation resulting from credit frictions in the U.S. and in South Korea respectively (but larger losses from a fall in aggregate capital).
} 
baseline parameters from Table 3 and continue to estimate relative productivity using equation (29). However, this time relative productivity is measured within firm-size groups (see Appendix B for details). We make three key observations. First, as suggested by Figure 1, the output losses due to credit frictions among SMEs are greater than for large firms - 33\% in Column (2) compared to $20 \%$ in Column (8). Second, the deterioration in credit frictions was larger and more persistent for SMEs.

In 2008 the effect of such frictions was a 30\% output loss for SMEs and 19\% for large firms, but in 2009 the size of the effect had risen to $34 \%$ and $21 \%$ respectively. Moreover, by the end of the sample period losses had returned to $19 \%$ for large firms, but remained high (at 35\%) for SMEs. This is consistent with evidence from Armstrong et al (2013) that financial constraints persisted for UK SMEs post crisis. Thirdly, the scale effects substantially dominate the TFP misallocation effect for both SMEs and large firms, as they did in the baseline results of Table 3 .

We also measure the extent of credit market frictions in the six broad sectors of the market sector (Table A14). Average losses vary between about a third and a quarter, so there is not an enormous degree of variation. The average output loss is highest in construction (32.6\%) and lowest in Wholesale and retail trade at $23.3 \%$. The growth contribution of credit frictions in 20082009 was $-5.3 \%$ for construction and $-2 \%$ for Wholesale and retail trade. The results are generally consistent with the idea that credit frictions are more severe in real-estate exposed sectors.

\subsection{A Wider Measure of Capital Market Distortions?}

A virtue of our approach is that we focus on a specific measurable aspect of credit frictions, that due to perceived default risk. But there are other potential sources of frictions in capital investment due, for example, to policy distortions and adjustment costs which prevent capital from being allocated to equalize marginal products. There is also the concern that default risk could depend on other information which is available to lenders, but which we do not have access to. It is useful therefore to compare our findings to those that would emerge in the more standard approach to the capital misallocation literature, such as Hsieh and Klenow (2009). Such an approach begins from the static first-order condition for the capital stock, measuring the capital 
market distortion as:

$$
\tau_{n t}^{K}=\frac{(\rho+\delta) K_{n t}}{\alpha \eta Y_{n t}}
$$

This requires an estimate of the capital stock and firm-level value added, which we have only in our smaller ABI/ABS sample. To forge a more exact comparison with existing work, we focus on manufacturing ${ }^{33}$ and continue, as above, to set $\rho=\delta=0.05$ which are the values used in Hsieh and Klenow (2009).

Although it does widen the range of possible capital market distortions, there is a well-known drawback with equation (34), namely that all of the measurement error in capital stocks and value added is now attributed to factor market distortions. For example, White, Reiter and Petrin (2018) show that even in the high-quality U.S. Census of Manufacturing, around three quarters of firms have some aspect of the elements underlying productivity calculations imputed. ${ }^{34}$ Nonetheless, it is interesting to make a comparison to assess how much larger the efficiency loss implied by this wider measure is. Since we need ABI/ABS data to estimate equation (34), we perform the methodological comparison using the $\mathrm{ABI} / \mathrm{ABS}$ sub-sample for the manufacturing sector.

Columns (2) to (7) of Table 5 replicate our baseline results of Table 3 for just manufacturing instead of the whole economy. The overall percentage loss of output is only slightly smaller than in the whole IDBR ( $25.9 \%$ vs. 27.5\%). ${ }^{35}$ As in Table 3, scale losses clearly dominate misallocation. In Columns (8) to (13) we estimate equation (34) and compute the associated output losses for the same sample. The overall losses in Column (9) are over twice as large as those estimated in Column (3) using our baseline method. They imply that capital market frictions depress manufacturing output by on average $64 \%$ per annum. Note that the framework of Hsieh and Klenow

\footnotetext{
${ }^{33}$ Our findings are qualitatively similar if we look at all sectors individually.

${ }^{34}$ Rotemberg and White (2017) show that trimming outliers lowers measured misallocation in Indian data compared to the U.S. - and therefore argue that the conclusions in Hsieh and Klenow (2009) are very sensitive to standard data cleaning procedures. Bils, Klenow and Ruane (2017) argue that there has been a large increase in measurement error in the plant-level U.S. productivity numbers over time.

${ }^{35}$ Note that this difference is not due to the reduced sample size in ABI/ABS. Appendix Table A4 indeed shows that in the entire ABI/ABS the estimated overall loss is $27.4 \%$, almost identical to that in the IDBR in Table 3. Weighting the sub-sample correctly is important for this result, as although the ABI/ABS has fewer firms than the IDBR (37,573 vs 1.5 million on average per year), these are the largest businesses in the economy.
} 
(2009) can only recover the TFP losses arising from an inefficient allocation of capital across firms with heterogeneous productivity (this is identified from the variance of the marginal revenue product of capital across firms). Although these TFP losses of about 5\% (Column (13)) are over twice as large as in our approach ( $2 \%$ in Column (7)), they remain much smaller than the scale effects ( $59 \%$ in Column (11)). In other words, output losses from misallocation are relatively small compared to the scale effects even when using the standard approach. The sample weighted mean of $\tau_{K}$ is 0.55 when we use default risk, while it is 0.32 using the standard approach (with a lower number reflecting larger credit frictions on average). There is also much more dispersion in the measure based on equation (34). The sample-weighted variance of $\tau_{K}$ is 0.07 when we use default risk, while it is 0.34 using the standard approach. In the misallocation literature a larger dispersion translates into larger TFP losses.

There are at least two reasons why the standard approach yields larger estimated losses compared to our method. First, it takes a more encompassing view of credit market distortions, whereas our measure only captures the fraction (about 40\%) due to the variation in estimated default probabilities. We do not, for example, allow lenders to "subsidize" inefficient firms (so-called "zombie firms") since we always have $\tau_{n t}^{K} \leq 1$. Second, we are arguably less susceptible to problems due to measurement error in observed capital stocks, something which a number of contributions have drawn attention to. Either way, there is a virtue in learning the lessons from a more specific approach to credit frictions, recognizing that in future it would be valuable to widen the range of factors considered where data is available.

\subsection{Labor Market Distortions}

We have so far focused on the case where the only factor market distortion is in credit markets. We now add the possibility of labor market distortions in order to see whether this changes the estimates of the output losses attributed to credit frictions. Although there are good reasons to expect labor markets to be imperfect (e.g. labor regulations, unions, adjustment costs and search frictions), we generally do not have direct measures of these frictions. Instead, we infer them from the data by using the fact that, from the firms' first-order conditions, the firm-level labor distortion is given by $\tau_{n t}^{L}=\frac{w_{t} L_{n t}}{(1-\alpha) \eta Y_{n t}}$, as in the standard approach of the previous subsection. These firm-level "labor taxes" can be estimated from firm-level data on payroll and value-added. We 
combine this with our measure of credit market distortions (default risk) to construct a measure of total distortions $\tau_{n t}$ faced by each firm as in equation (16).

We are less interested in labor market distortions per se but rather in whether adding them affects our core findings on the importance of credit market distortions. Specifically, we set $\tau_{n t}^{K}=1$, i.e. eliminate default risk completely while keeping labor market frictions in place. This implies that the benchmark $\hat{\Theta}_{t}$ is less than one. The impact of allowing for labor market frictions is not clear a priori since it will depend on how the estimates of labor and credit market frictions are correlated in the data. ${ }^{36}$ The results are in Table A5. We use the ABI/ABS sample as we need payroll and value added. Implementing this exercise leads to results that are only slightly smaller than the core results - credit frictions reduce output by $23 \%$ instead of $27 \%$ on average.

\subsection{Some Further Robustness Tests}

Although the exact magnitude of the estimates vary somewhat, our main findings survive a range of robustness checks.

Alternative Parameter Values The two key parameter values that we use are the returns to scale parameter $(\eta=0.85)$ and the output-capital elasticity $(\alpha=1 / 3)$. We show the sensitivity of the results to a wide range of these values in Table A6, ranging from $\eta=0.75$ to $\eta=0.95$ and $\alpha=0.25$ to $\alpha=0.41$. For a given $\alpha$, the losses increase in $\eta$. In the baseline where $\alpha=1 / 3$, the losses increase from $20 \%$ for $\eta=0.75$ to $48 \%$ for $\eta=0.95$. This is intuitive as moving closer to constant returns to scale allocates more output to the most productive firms, hence when they have higher default risk this weighs more negatively on output. ${ }^{37}$ For a given $\eta$, the losses also increase in $\alpha$. Unsurprisingly, when capital is more important in production, the output losses from credit frictions increase. In the baseline where $\eta=0.85$, moving from the lowest level of $\alpha$ to the highest level increases the output loss from $18 \%$ to $39 \%$.

\footnotetext{
${ }^{36}$ The correlation between repayment probabilities and $\tau_{n t}^{L}$ is negative and significant at the $1 \%$ level. Since frictions are negatively correlated, they will tend to offset each other to some extent.

${ }^{37}$ See Garicano et al (2016) for a similar result on the welfare cost of labor regulations.
} 
Our baseline approach used a constant value of $\alpha$ across industries, which could have different production technologies. So, as a robustness check, we estimated values of $\alpha$ using the empirical shares of labor costs in value added separately for each three-digit industry (see Appendix B). Allowing for such heterogeneity does not change the aggregate output losses of Table 3 materially. The average output loss is slightly smaller at $24.6 \%$ and the growth contribution between 2008 and 2009 is $-3.3 \%$ (see Table A7).

Finally, we test the sensitivity of the results to a change in the depreciation rate. Specifically, Appendix Table A8 doubles the depreciation rate and shows that this reduces output losses (from $27.5 \%$ to $21 \%$ ) as expected. The losses due to default risk decrease in $\delta$ because, for a given level of default represented by $\phi$, a higher value of $\delta$ implies that default risk represents a smaller proportion of the overall cost of capital. This translates into smaller losses due to default risk relative to the benchmark.

An Alternative Measure of Productivity: Solow Residuals Our baseline approach imputes relative firm-level productivity using the size distribution and data on default risk following our theoretical model. Alternatively, one could try to estimate productivity directly. As a robustness check, we use Solow residuals (see Appendix B) to estimate firm-level productivity. We favor our baseline approach over Solow residuals (and TFP estimates) for several reasons. First, Solow residuals are subject to measurement error (due in part to measurement errors in the estimates of firm-level capital stocks). Second, they are revenue-based measures of TFPR as we do not have firm-specific prices. Hence, they may reflect mark-up differences rather than fundamental TFPQ differences $(\theta)$. Finally, any estimates will be contaminated by the very frictions we are attempting to quantify, since frictions affect value added, and labor and capital inputs.

The estimation of Solow residuals requires data on output and factor inputs, so we use the ABI/ABS sample (both manufacturing and non-manufacturing). The results are in Appendix Table A9. We find that the average magnitude of the output loss is smaller (19\% in Table A9 vs. $27 \%$ in Table A4).$^{38}$ Credit frictions explain roughly $43 \%$ of the productivity fall between 2008 and 2009 . The patterns of heterogeneity across size categories are qualitatively similar

\footnotetext{
${ }^{38}$ Note that the sample used in Table A9 is slightly smaller than the entire ABI/ABS in Table A4. This is because we condition on non-missing values for real value added and factor inputs, including capital stock estimates.
} 
to the baseline estimates (not reported). The relative importance of the scale and TFP components is also similar, with the scale effects clearly dominating. We conclude that mismeasurement of relative productivity with Solow residuals leads us to underestimate output losses due to credit frictions (both scale and TFP effects).

Time-varying Funding Cost In our baseline results, we follow Hsieh and Klenow (2009) and the extant literature in setting $\rho=\delta=5 \%$. We relax this by allowing $\rho$ to vary over time. We measure $\rho_{t}$ as the sum of the annual average official Bank Rate and the annual average Credit Default Swap (CDS) premium of the six largest UK banks. The results are in Table A10. The average annual loss of output now stands at 30.4\% - slightly higher than our baseline result. The time series pattern however is more striking. The growth contribution of credit frictions in 2009 amounts to $-14.8 \%$ - compared with $-4.8 \%$ in our baseline. This is due to a large endogenous decrease in the annual average official Bank Rate (from $4.68 \%$ in 2008 to $0.64 \%$ in 2009), which causes default risk to become a larger proportion of the overall cost of capital. This endogenous response could potentially lead us to overestimate the impact of credit frictions, which is why we favor setting $\rho=5 \%$.

Dropping Imputed Default Probabilities As noted in the data section, we predict missing risk scores in order to be able to exploit the full IDBR dataset. As a robustness check, we drop all the predicted values and rely solely on the raw data to ensure that this does not create a large bias. Appendix Tables A11 and A12 present the results for the IDBR and for the $\mathrm{ABI} / \mathrm{ABS}$, respectively. When we use these smaller samples, we construct our own set of sampling weights in order to capture aggregate developments. All our results are robust to working solely with the non-imputed data. The estimated losses are similar to those obtained with the entire samples, although slightly larger (e.g. 30.4\% for the IDBR in Table A11 compared to $27.5 \%$ in Table 3$)$. It is noticeable that the non-imputed IDBR sample covers $74 \%$ of aggregate employment because firms with missing PDs tend to be very small, which is why imputing missing PDs makes little difference to the aggregate results. 


\section{Conclusion}

This paper develops a novel theoretically-grounded approach to credit market frictions using firm-level data. We use the "Probability of Default (PD) Model" and "CreditPro" data of Standard and Poor's, which are credit scoring tools of the type used by lenders prior to making loans, to estimate a time-varying default probability for the population of UK firms. We show that the default probability from the PD Model predicts firm-level decisions as suggested by the theory, even conditional on firm fixed-effects.

The framework allows us to assess the impact of default risk on aggregate economic performance. We find that credit frictions depress economic output by $28 \%$ over the $2005-2013$ period on average. These frictions increased sharply in the Great Recession, accounting for over half of the observed $9.3 \%$ fall in productivity between 2008 and 2009. Smaller firms were particularly hard hit by the banking crisis and the increase in frictions has largely been driven by the SME segment. This shows the value of allowing heterogeneity among firms when looking at these issues. We show that most of the impact of credit frictions comes from the average assessment of default risk (the scale effect) rather than the way in which capital is distributed across firms with different productivity levels (the TFP, i.e. misallocation effect).

We have focused on a specific measurable aspect of credit market frictions and the fact that we anchor the empirical analysis in a simple model permits counterfactual exercises including an estimate of what output would be in the absence of default risk. That said, there could be other aspects of frictions in capital markets which are not picked up by our focus on default risk. It does not, for example, assess the possibility that "zombie firms", i.e. those which benefit from lender forbearance, depress output and productivity (see Andrews and Petroulakis, 2017). This explains why the standard approach to capital market inefficiencies generates larger output losses than the ones based exclusively on default risk. Trying to apportion the components of capital misallocation to specific and measurable distortions in a range of dimensions is an important challenge for the research agenda in future. ${ }^{39}$

\footnotetext{
${ }^{39}$ Future work could also integrate our approach with the literature on how bank connections affected the impact of the global financial crisis - see e.g. Chodorow-Reich (2014), Huber (2018), and Anderson et al (2019). Although these papers have cleaner causal identification of the impact of the crisis on firms, it is harder to aggregate these up to general equilibrium output effects - which is the focus of our paper (see Sylvain et al, 2018, for a similar point). In our framework, these connected firms might suffer a larger
} 
Our focus on default risk leaves a substantial fraction of the weak productivity performance unaccounted for. This residual may potentially be explained by other factors, beyond just having richer models of capital market frictions, such as chronically weak demand (Summers, 2016), a slowdown of technological change (Gordon, 2016) and/or research productivity (Bloom, Jones, Van Reenen and Webb, 2019), mismeasurement (Syverson, 2017), unobserved experimentation and investment in intangible capital (Brynjolfsson et al, 2017), among others. More work is needed to apportion the relative importance of these factors in explaining the evolution of aggregate productivity.

Overall, our results underline that firm-level assessments of default risk are a useful way of understanding credit frictions and the financial crisis. Moreover, the approach highlights the value of automated scoring tools used by lenders for assessing the impact of credit market frictions using firm-level data. The framework can be applied with parsimonious data requirements and opens up the "black box" of credit frictions in a novel way linked to an underlying theory.

\section{References}

Acharya, Viral V., Tim Eisert, Christian Eufinger and Christian W. Hirsch (2015) "Real effects of sovereign debt crisis in Europe: Evidence from syndicated loans" NYU mimeo.

Aghion, Philippe, Emmanuel Farhi, and Enisse Kharroubi (2012) "Monetary Policy, Liquidity, and Growth" Review of Economics and Statistics, 91:1, 20-32.

Aghion, Philippe, David Hemous and Enisse Kharroubi (2014). "Credit Constraints, Cyclical Fiscal Policy and Industry Growth" Journal of Monetary Economics, 62 (March): 41-58.

Amaral, Pedro S., and Erwan Quintin (2010) "Limited enforcement, financial intermediation, and economic development: a quantitative assessment", International Economic Review, 51:785-811.

Amiti, Mary and David Weinstein (2018) "How Much do Idiosyncratic Bank Shocks Affect Investment? Evidence from Matched Bank-Firm Loan Data" Journal of Political Economy 126(2) 525-587

exogenous change in their default probabilities, $\phi_{n t}$, and therefore their capital taxes, $\tau_{n t}^{K}$. These designs could be used as instruments for the treatment effects which could in turn be exploited as well-identified micro-moments to offer a richer application of our model. See Nakamura and Steinsson (2018) for a general argument for this approach in modern macro-economics and Herreno (2019) for an application to bank lending cuts. 
Andrews, Dan and Filippos Petroulakis (2017) "Breaking the Shackles: Zombie Firms, Weak Banks and Depressed Restructuring in Europe", OECD Economics Department Working Papers, No. 1433, OECD Publishing, Paris.

Anderson, Gareth, Rebecca Riley and Garry Young (2019) "Distressed Banks, Distorted Decisions" NIESR Discussion Paper No. 503

Armstrong, Angus, Phillip Davis, Iana Liadze and Cinzia Rienzo (2013) "Evaluating changes in bank lending to SMEs over 2001-2012" National Institute for Economic Social Research Discussion Paper 408.

Asker, John, Allan Collard-Wexler and Jan De Loecker (2014) "Dynamic Inputs and Resource (Mis)Allocation" Journal of Political Economy, 122(5), $1013-1063$.

Banerjee, Abhijit V. and Esther Duflo (2014) "Do Firms Want to Borrow More? Testing Credit Constraints Using a Directed Lending Program", The Review of Economic Studies, 81, 572-607.

Bank of England (2014), Trends in Lending, January 2014.

Baqaee, David and Emmanuel Fahri (2017) "Productivity and Misallocation in General Equilibrium", NBER Working Paper 24007.

Barnett, Alina, Chiu, Adrian, Franklin, Jeremy and Sebastia-Barriel, Maria (2014a) "The productivity puzzle: A firm-level investigation into employment behavior and resource allocation over the crisis", Bank of England Working Paper No. 495.

Barnett, Alina, Ben Broadbent, Adrian Chiu, Jeremy Franklin and Helen Miller (2014b) "Impaired capital reallocation and productivity", National Institute Economic Review, 228.

Bartelsman, Eric, Haltiwanger, John and Scarpetta, Stefano (2013) "CrossCountry Differences in Productivity: The Role of Allocation and Selection", American Economic Review, 103, 305-334.

Benford, James and Oliver Burrows (2013). Commercial property and financial stability. Bank of England Quarterly Bulletin 2013 Q1.

Benmelech, Efraim and Nittai K. Bergman (2008) "Liquidation Values and the Credibility of Financial Contract Renegotiation: Evidence from U.S. Airlines," Quarterly Journal of Economics, 123 (4), 1635-1677.

Benmelech, Efraim, Carola Frydman, and Dimitris Papanikolaou, (2019) "Financial Frictions and Employment during the Great Depression," Journal of Financial Economics, 133 (3), 541-563.

Benito, Andrew, Katherine Neiss, Simon Price, and L. Rachel, (2010) "The impact of the financial crisis on supply", Bank of England Quarterly Bulletin 2010 Q2, 50, 104-14.

Bentolila, Samuel, Marcel Jansen, Gabriel Jimenez (2018) "When Credit Dries Up: Job Losses in the Great Recession", Journal of the European Economic Association, 16(3), 650-695.

Bernanke, Ben. S., and Mark Gertler (1989) "Agency Costs, Net Worth, and Business Fluctuations," American Economic Review, 79(1), 14-31.

Besley, Timothy, Konrad Burchardi and Maitreesh Ghatak (2012) "In- 
centives and the de Soto effect", Quarterly Journal of Economics, 127(1), 237-282.

Besley, Timothy and Hannes Mueller, (2018) "Predation, Protection, and Productivity: A Firm-Level Perspective," American Economic Journal: Macroeconomics, 10(2), 184-221.

Besley, Timothy and John Van Reenen (2013) Investing for Prosperity, London: LSE Growth Commission.

Bils, Mark, Peter J. Klenow, and C. Ruane (2017) "Misallocation or mismeasurement?" Stanford mimeo.

BIS, Department for Business, Innovation and Skills (2010) Financing a Private Sector Recovery.

Bloom, Nick, Chad Jones, John Van Reenen and Michael Webb (2019) "Are ideas becoming harder to find?", CEP Discussion Paper 1496, forthcoming American Economic Review

Bond, Steve, and John Van Reenen (2007) Microeconometric Models of Investment and Employment, Handbook of Econometrics Volume 6A, Chapter 65 (eds: Edward Leamer and James Heckman)

Bovill, H. (2012). "Annual Business Survey, Technical Report", Office for National Statistics.

Byrne, David, John Fernald and Marshall Reinsdorf (2016) "Does the United States have a productivity slowdown or a measurement problem?", Brookings mimeo.

Brynjolfsson, Erik, Daniel Rock, Chad Syverson (2017) "Artificial Intelligence and the Modern Productivity Paradox: A Clash of Expectations and Statistics", NBER Working Paper No. 24001.

Buera, Francisco J., and Yongseok Shin (2013) "Financial frictions and the persistence of history: a quantitative exploration", Journal of Political Economy, 121 (2), pp.221-272.

Caselli, Francesco, and Nicola Gennaioli (2013) "Dynastic management", Economic Inquiry, Vol.51, No.1, 971-996.

Catherine, Sylvain, Thomas Chaney, Zongbo Huang, David A. Sraer, and David Thesmar (2018) "Aggregate effects of collateral constraints", Working paper.

Chaney, Thomas, David Sraer, and David Thesmar (2012) "The Collateral Channel: How Real Estate Shocks Affect Corporate Investment", American Economic Review, 102(6) 2381-2409.

Chodorow-Reich, Gabriel (2014) "The Employment Effects of Credit Market Disruptions: Firm-level Evidence from the 2008-09 Financial Crisis", Quarterly Journal of Economics 129(1): 1-59.

Competition Commission (2002) Inquiry into SME Banking.

Cooley, Thomas, F., and Vincenzo Quadrini (2001) "Financial Markets and Firm Dynamics", American Economic Review, 91(5), 1286-1310.

Cruickshank Report into competition in UK banking (2000).

De Loecker, Jan and Alan Collard-Wexler (2016) "Production Function Estimation with Measurement Error in Inputs", Princeton mimeo. 
De Ridder, Geert (2017) "Investment in Productivity and Long-run Effect of Financial Crises on Output", Cambridge mimeo.

Disney, Richard, Jonathan Haskel, and Y. Heden, (2003) "Restructuring and productivity growth in UK manufacturing", Economic Journal, 113, 666-694

Faulkender, Michael and Mitchell Petersen (2012) "Investment and Capital Constraints: Repatriations Under the American Jobs Creation Act," Review of Financial Studies, 25 (11), 3351-3388.

Foster, Lucia, John Haltiwanger, and C.J. Krizan (2002) "The Link Between Aggregate and Micro Productivity Growth: Evidence from Retail Trade", NBER Working Paper No. 9120.

Foster, Lucia, John Haltiwanger, and Chad Syverson (2008) "Reallocation, firm turnover, and efficiency: Selection on productivity or profitability?" American Economic Review, 98(1), 394-425.

Franklin, Jeremy, May Rostom and Gregory Thwaites (2015) "The banks that said no: banking relationships, credit supply and productivity in the United Kingdom", Bank of England Staff Working Paper No. 557.

Gan, Jie (2007) "Collateral, debt capacity, and corporate investment: Evidence from a natural experiment", Journal of Financial Economics, 85(3), 709-734.

Garcia-Macia, Daniel (2017) "The financing of ideas and the great deviation ", IMF mimeo.

Garicano, Luis, Claire Lelarge and John Van Reenen (2016) "Firm Size Distortions and the Productivity Distribution: Evidence from France" American Economic Review 106(11) 3439-79

Garicano, Luis and Claudia Steinwender (2016) "Survive Another Day: Using Changes in the Composition of Investments to Measure the Cost of Credit Constraints ", Review of Economics and Statistics, 98(5), 913-924.

Gilchrist, Simon, Jae W. Sim and Egon Zakrajsek (2013) "Misallocation and Financial Market Frictions: Some Direct Evidence from the Dispersion in Borrowing Costs", Review of Economic Dynamics, 16(1), 159-176.

Gilchrist, Simon, and Egon Zakrajsek (2012) "Credit Spreads and Business Cycle Fluctuations", American Economic Review 2012, 102(4), 16921720.

Gopinath, Gita, Sebnem Kalemli-Ozcan, Loukas Karabarbounis and Carolina Villegas-Sanchez (2017), "Capital Allocation and Productivity in South Europe", Quarterly Journal of Economics, 132(4), 1915-1967

Gordon, Robert (2016) The Rise and Fall of American Growth Princeton: Princeton University Press.

Greenstone, Michael, Alexander Mas and Hoai-Luu Nguyen (2014) "Do Credit Market Shocks affect the Real Economy? Quasi-Experimental Evidence from the Great Recession and 'Normal' Economic Times", NBER Working Paper No. 20704.

Griffith, Rachel (1999) "Using the ARD establishment level data to look at foreign ownership and productivity in the United Kingdom", Economic 
Journal, 109 (456).

Herreno, Juan (2019) "The Aggregate Effect of Bank Lending Cuts", Columbia University mimeo

Holmstrom, Bengt and Jean Tirole, (1997), "Financial Intermediation, Loanable Funds and the Real Sector," Quarterly Journal of Economics, 112(3), 663-691.

Hsieh, Chang-Tai and Peter J. Klenow (2009) "Misallocation and Manufacturing TFP in China and India" Quarterly Journal of Economics 124 (4):1403-1448.

Hsieh, Chang-Tai and Peter J. Klenow (2014) "The Life Cycle of Plants in India and Mexico", Quarterly Journal of Economics, Volume 129, Issue 3.

Hopenhayn, Hugo A. (2014) "Firms, Misallocation, and Aggregate Productivity: A Review", Annual Review of Economics, 6:735-70.

Huber, Kilian (2018) "Disentangling the Effects of a Banking Crisis: Evidence from German Firms and Counties", American Economic Review 108(3) $868-98$

Independent Commission on Banking (2011) Final Report.

Innes, Robert D., (1990), "Limited Liability and Incentive Contracting with Ex-Ante Action Choices," Journal of Economic Theory, 52, 45-67.

Jeong, Hyeok and Robert M. Townsend (2007) "Sources of TFP growth: occupational choice and financial deepening", Economic Theory, 32:179-221.

Kalemli-Ozcan, Sebnem, Bent Sorensen, Carolina Villegas-Sanchez, Vadym Volosovych, and Sevcan Yesiltas (2015) "How to construct nationally representative firm level data from the Orbis global database", NBER Working Paper 21558.

Kay, John (2012) The Kay Review of UK Equity Markets and Long-term Decision-making London: HMSO.

Khwaja, Asim and Atif Mion (2008) "Tracing the Impact of Bank Liquidity Shocks: Evidence from an Emerging Market", American Economic Review 98(4): 1413-42.

Lamont, Owen, (1997) "Cash Flow and Investment: Evidence from Internal Capital Markets," Journal of Finance, 52 (1), 83-109.

Lemmon, Michael and Michael R. Roberts, (2010) "The Response of Corporate Financing and Investment to Changes in the Supply of Credit," Journal of Financial and Quantitative Analysis, 45 (03), 555-587.

Lucas, Robert (1978) "On the Size distribution of business firms", Bell Journal of Economics, 9(2) 508-523.

Manaresi, Francesco and Nicola Pierri (2019) "Credit Supply and Productivity Growth", IMF Working Paper No. 19/107.

Mian, Atif and Amir Sufi (2018) "Finance and Business Cycles: The Credit-Driven Household Demand Channel" Journal of Economic Perspectives, 32(3), 31-58.

Midrigan, Virgiliu, and Daniel Yi Xu (2014) "Finance and Misallocation: 
Evidence from Plant-Level Data ", American Economic Review 104(2): 422458.

Moll, Benjamin (2014) "Productivity Losses from Financial Frictions: Can Self-Financing Undo Capital Misallocation?", American Economic Review, 104(10) 3186-3221.

Nakamura, Emi and Jón Steinsson (2018) "Identification in Macroeconomics" The Journal of Economic Perspectives 32(3) 59-86

Office for National Statistics (2012) Annual Respondents Database, 19732008: Secure Access. 3rd Edition. UK Data Service. SN: 6644 http://doi.org/10.5255/UKDASN-6644-5.

Office for National Statistics (2018) Annual Business Survey, 2008-2016:

Secure Access. 9th Edition. UK Data Service. SN: 7451, http://doi.org/10.5255/UKDASN-7451-9.

Office of Budget Responsibility (2017) Economic and Fiscal Outlook, November, London: HMSO.

Office of Fair Trading (2006) Survey of SME Banking. London: HMSO.

Office of Fair Trading (2010) Review of Barriers to Entry, Expansion and Exit in Retail Banking. London: HMSO.

Rauh, Joshua D. (2006) "Investment and Financing Constraints: Evidence from the Funding of Corporate Pension Plans," Journal of Finance, 61 (1), 33-71.

Reinhart, Carmen and Kenneth Rogoff, (2011) This Time Is Different: Eight Centuries of Financial Folly, Princeton, New Jersey: Princeton University Press.

Restuccia, Diego and Richard Rogerson (2008) "Policy distortions and aggregate productivity with heterogeneous establishments", Review of Economic Dynamics 11:707-720.

Riley, Rebecca, Chiara Rosazza-Bondibene and Garry Young (2015) "The UK productivity puzzle 2008-13: evidence from British businesses", Bank of England Staff Working Paper No. 531.

Rotemberg, Martin and T. Kirk White (2017) "Measuring Cross-Country Differences in Misallocation", NYU mimeo.

Stiglitz, Joseph E., and Andrew Weiss (1981) "Credit Rationing in Markets with Imperfect Information," American Economic Review, 71(3), 393410.

Sylvain, Catherine, David Sraer, David Thesmar, Thomas Chaney and Zongbo Huang (2018) "Quantifying Reduced-Form Evidence on Collateral Constraints", MIT mimeo.

Summers, Larry (2016) "What is secular stagnation and what can we do about it?", Foreign Affairs, March.

Syverson, Chad (2017) "Challenges to Mismeasurement explanations for the U.S. productivity slowdown", Journal of Economic Perspectives Spring.

White, Kirk, Jerome Reiter and Amil Petrin (2018) "Imputation in U.S. Manufacturing Data and Its Implications for Productivity Dispersion", Review of Economics and Statistics 100(3) 502-509 
Zia, Bilal (2008) "Export incentives, financial constraints, and the (mis)allocation of credit: Micro-level evidence from subsidized export loans," Journal of Financial Economics, 87 (2), 498-527.

Zwick, Eric and James Mahon, (2017) "Tax Policy and Heterogeneous Investment Behavior," American Economic Review, 107(1) 217-48. 
Figure 1: Aggregate probability of default (in \%) in the market sector, broken down by firm size

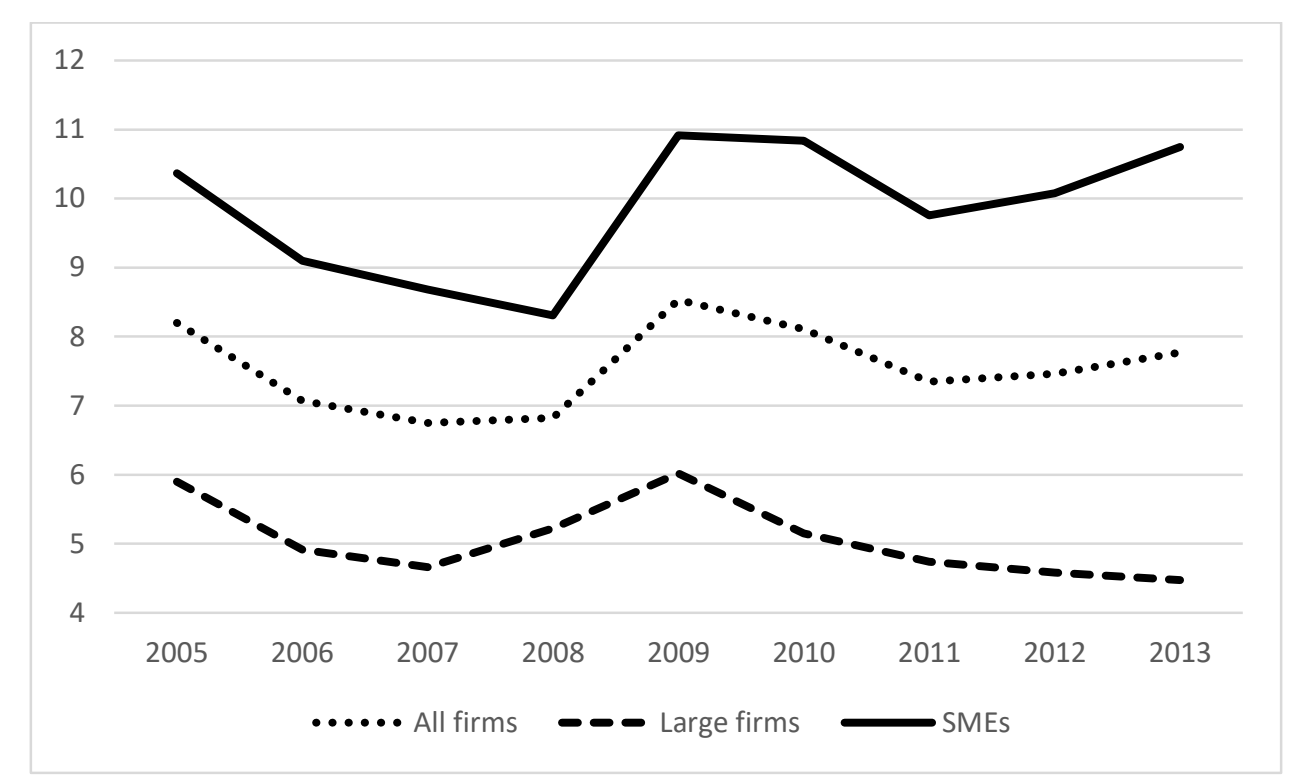

Notes: A firm's default probability is given by the probability that it will default on its payments at the one-year horizon according to S\&P's PD Model and historical default rates from S\&P's CreditPro. SMEs (solid line) are Small and Medium-Sized Enterprises defined as firms with fewer than 250 employees. Large firms (long dashed line) are firms with 250 employees or more. Firm-level default probabilities are aggregated using employment weights. The sample is the IDBR market sector (See Table 1 for underlying sample sizes). 
Figure 2: Annual distribution of risk scores across firms in the market sector

\section{Panel A: Every year}

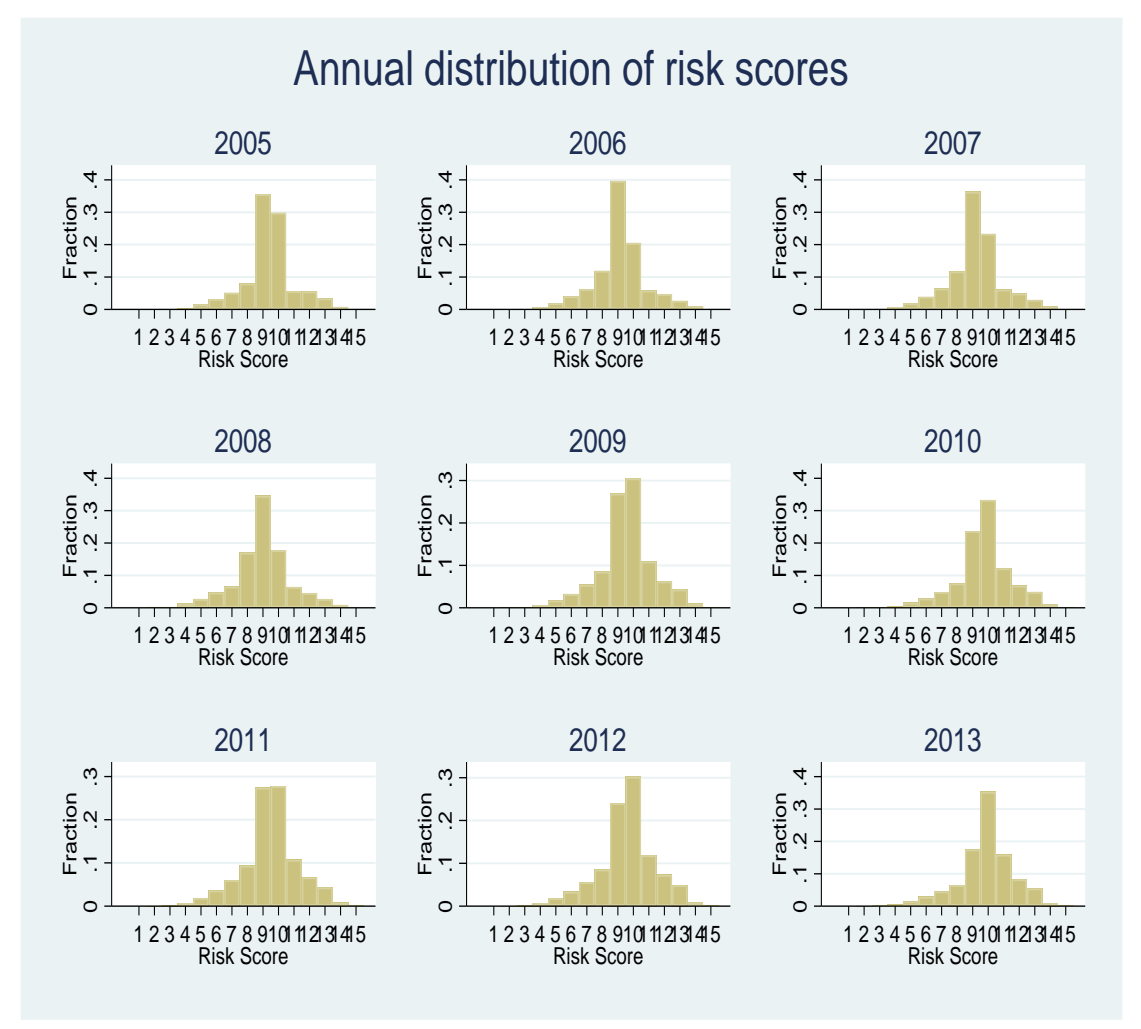

Panel B: First year compared to last year

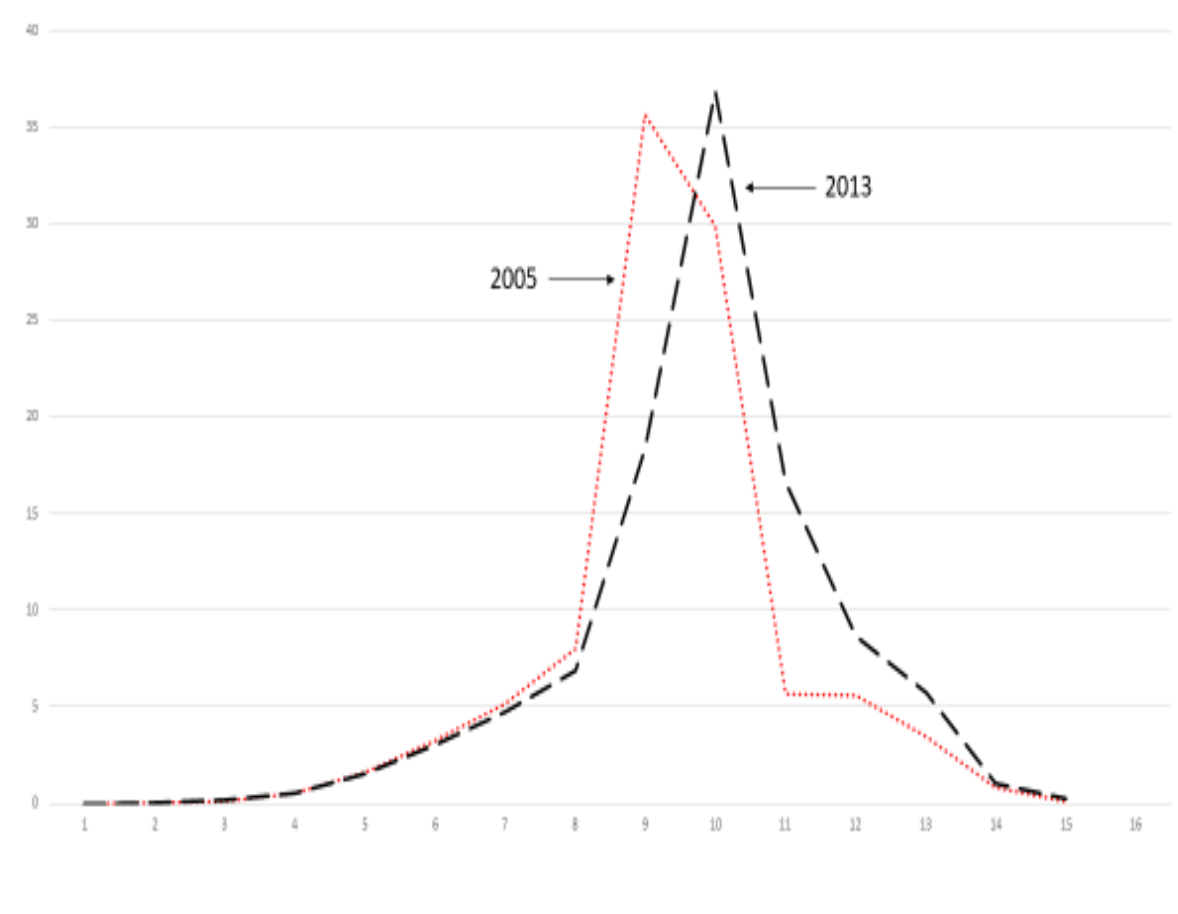

Notes: The chart shows the fraction of firms in each risk band, defined from 1 to 15 , by year. The risk categories $1-15$ correspond to risk scores as follows: $1=$ $\mathrm{AAA}$ to $\mathrm{A}-, 2=\mathrm{BBB}+, 3=\mathrm{BBB}, 4=\mathrm{BBB}-, 5=\mathrm{BB}+, 6=\mathrm{BB}, 7=\mathrm{BB}-, 8=\mathrm{B}+, 9=\mathrm{B}, 10=\mathrm{B}-, 11=\mathrm{CCC}+, 12=\mathrm{CCC}, 13=\mathrm{CCC}-14=\mathrm{CC}$, and $15=\mathrm{C}$. We group risk scores AAA to A- into one category to adhere to the disclosure rules of the UK Data Service. See Table 1 for underlying sample sizes. The average default rates in each bin are given in Table A1. For example, the average default rate in bin $5(\mathrm{BB}+)$ is $0.51 \%$ compared to $23 \%$ in bin $11(\mathrm{CCC}+)$. 
Table 1: Employment and firms in the market sector, broken down by firm size

\begin{tabular}{|c|c|c|c|c|c|c|c|c|}
\hline & (1) & (2) & (3) & (4) & $(5)$ & (6) & (7) & (9) \\
\hline & $\begin{array}{c}\text { Total } \\
\text { employment }\end{array}$ & $\begin{array}{c}\text { Total } \\
\text { \# firms }\end{array}$ & $\begin{array}{c}\text { SME } \\
\text { employment }\end{array}$ & $\begin{array}{c}\text { \% of total } \\
\text { employment }\end{array}$ & \# SMEs & $\begin{array}{l}\text { Large firm } \\
\text { employment }\end{array}$ & $\begin{array}{c}\% \text { of total } \\
\text { employment }\end{array}$ & $\begin{array}{c}\text { \# large } \\
\text { firms }\end{array}$ \\
\hline 2005 & $15,604,279$ & $1,377,733$ & $8,010,385$ & 51.33 & $1,371,906$ & $7,593,894$ & 48.67 & 5,827 \\
\hline 2006 & $15,661,572$ & $1,414,221$ & $8,069,069$ & 51.52 & $1,408,569$ & $7,592,503$ & 48.48 & 5,652 \\
\hline 2007 & $15,469,375$ & $1,460,639$ & $8,026,261$ & 51.88 & $1,455,388$ & $7,443,114$ & 48.12 & 5,251 \\
\hline 2008 & $16,211,576$ & $1,545,919$ & $8,401,511$ & 51.82 & $1,540,225$ & $7,810,065$ & 48.18 & 5,694 \\
\hline 2009 & $15,929,213$ & $1,480,481$ & $8,159,385$ & 51.22 & $1,474,989$ & $7,769,828$ & 48.78 & 5,492 \\
\hline 2010 & $15,328,929$ & $1,459,680$ & $7,955,473$ & 51.90 & $1,454,545$ & $7,373,456$ & 48.10 & 5,135 \\
\hline 2011 & $15,469,622$ & $1,502,427$ & $8,055,901$ & 52.08 & $1,497,247$ & $7,413,721$ & 47.92 & 5,180 \\
\hline 2012 & $15,731,791$ & $1,502,665$ & $8,221,274$ & 52.26 & $1,497,445$ & $7,510,517$ & 47.74 & 5,220 \\
\hline 2013 & $16,040,370$ & $1,569,340$ & $8,417,354$ & 52.48 & $1,564,028$ & $7,623,016$ & 47.52 & 5,312 \\
\hline Average & $15,716,303$ & $1,479,234$ & $8,146,290$ & 51.83 & $1,473,816$ & $7,570,013$ & 48.17 & 5,418 \\
\hline
\end{tabular}

Notes: Data from the "Market sector" using IDBR - all sectors covered except financial services, non-market service sectors (e.g. education, health, social work and the public sector), agriculture, mining and quarrying, utilities, real estate, government and non-profit organizations. SMEs are firms with strictly fewer than 250 employees and large firms are those with 250 or more employees. 
Table 2: Firm performance and lagged repayment probabilities

PANEL A: Controls for industry and year fixed effects

\begin{tabular}{|c|c|c|c|c|c|c|c|c|c|c|c|}
\hline & $\begin{array}{c}\text { (1) } \\
\begin{array}{c}\text { Ln(employ } \\
\text { ment) }\end{array} \\
\end{array}$ & $\begin{array}{c}\text { (2) } \\
\begin{array}{c}\text { Ln(employ } \\
\text { ment) }\end{array} \\
\end{array}$ & $\begin{array}{c}\text { (3) } \\
\text { Ln(vale } \\
\text { added) }\end{array}$ & $\begin{array}{c}(4) \\
\begin{array}{c}\text { Ln(capital } \\
\text { stock) }\end{array} \\
\end{array}$ & $\begin{array}{c}\text { (5) } \\
\begin{array}{c}\text { Ln(invest } \\
\text { ment) }\end{array} \\
\end{array}$ & $\begin{array}{c}\text { (6) } \\
\text { Ln(total } \\
\text { assets) }\end{array}$ & $\begin{array}{c}\text { (7) } \\
\text { Ln(fixed } \\
\text { assets) }\end{array}$ & $\begin{array}{c}\text { (8) } \\
\begin{array}{c}\text { Ln(capital/ } \\
\text { labor) }\end{array} \\
\end{array}$ & $\begin{array}{c}(9) \\
\text { Ln(invest } \\
\text { ment/ } \\
\text { labor) }\end{array}$ & $\begin{array}{c}(10) \\
\text { Ln(invest } \\
\text { ment/ } \\
\text { capital) }\end{array}$ & (11) \\
\hline $\begin{array}{l}\text { Ln(Repay } \\
\text { ment } \\
\text { prob) } \\
\end{array}$ & $\begin{array}{c}0.390 * * * \\
(0.004)\end{array}$ & $\begin{array}{c}1.680 * * * \\
(0.044)\end{array}$ & $\begin{array}{c}2.445 * * * \\
(0.057)\end{array}$ & $\begin{array}{c}2.540 * * * \\
(0.072)\end{array}$ & $\begin{array}{c}2.535 * * * \\
(0.096) \\
\end{array}$ & $\begin{array}{c}3.733 * * * \\
(0.062)\end{array}$ & $\begin{array}{c}4.542 * * * \\
(0.075)\end{array}$ & $\begin{array}{c}0.360 * * * \\
(0.041)\end{array}$ & $\begin{array}{c}1.062 * * * \\
(0.058)\end{array}$ & $\begin{array}{c}0.586^{* * * *} \\
(0.049)\end{array}$ & $\begin{array}{c}0.045 * * * \\
(0.001)\end{array}$ \\
\hline Data & IDBR & $\mathrm{ABI} / \mathrm{ABS}$ & $\mathrm{ABI} / \mathrm{ABS}$ & $\mathrm{ABI} / \mathrm{ABS}$ & $\mathrm{ABI} / \mathrm{ABS}$ & ORBIS & ORBIS & $\mathrm{ABI} / \mathrm{ABS}$ & $\mathrm{ABI} / \mathrm{ABS}$ & $\mathrm{ABI} / \mathrm{ABS}$ & IDBR \\
\hline $\begin{array}{l}\text { Observatio } \\
\text { ns }\end{array}$ & $10,194,209$ & 271,038 & 254,366 & 204,951 & 110,274 & 195,010 & 179,796 & 204,951 & 110,274 & 100,650 & $4,845,158$ \\
\hline
\end{tabular}

PANEL B: Controls for industry, year, and firm fixed effects

\begin{tabular}{|c|c|c|c|c|c|c|c|c|c|c|c|}
\hline & $\begin{array}{c}\text { (1) } \\
\text { Ln(employ } \\
\text { ment) }\end{array}$ & $\begin{array}{c}\text { (2) } \\
\text { Ln(employ } \\
\text { ment) }\end{array}$ & $\begin{array}{c}\text { (3) } \\
\text { Ln(vale } \\
\text { added) }\end{array}$ & $\begin{array}{c}(4) \\
\begin{array}{c}\text { Ln(capital } \\
\text { stock) }\end{array}\end{array}$ & $\begin{array}{c}\text { (5) } \\
\text { Ln(invest } \\
\text { ment) }\end{array}$ & $\begin{array}{c}\text { (6) } \\
\text { Ln(total } \\
\text { assets) }\end{array}$ & $\begin{array}{c}\text { (7) } \\
\text { Ln(fixed } \\
\text { assets) }\end{array}$ & $\begin{array}{c}\text { (8) } \\
\begin{array}{c}\text { Ln(capital/ } \\
\text { labor) }\end{array}\end{array}$ & $\begin{array}{c}(9) \\
\text { Ln(invest } \\
\text { ment/ } \\
\text { labor) }\end{array}$ & $\begin{array}{c}(10) \\
\text { Ln(invest } \\
\text { ment/ } \\
\text { capital) }\end{array}$ & Survival \\
\hline $\begin{array}{l}\text { Ln(Repay } \\
\text { ment } \\
\text { prob) }\end{array}$ & $\begin{array}{c}0.007 * * * \\
(0.002)\end{array}$ & $\begin{array}{c}0.034 * * \\
(0.015)\end{array}$ & $\begin{array}{c}0.352 * * * \\
(0.034)\end{array}$ & $\begin{array}{c}0.076^{* * *} \\
(0.019)\end{array}$ & $\begin{array}{c}0.712 * * * \\
(0.069)\end{array}$ & $\begin{array}{c}0.277 * * * \\
(0.038)\end{array}$ & $\begin{array}{c}0.369 * * * \\
(0.038)\end{array}$ & $\begin{array}{c}0.043 * * \\
(0.022)\end{array}$ & $\begin{array}{c}0.687 * * * \\
(0.068)\end{array}$ & $\begin{array}{c}0.664 * * * \\
(0.063)\end{array}$ & $\begin{array}{c}0.004 * * * \\
(0.001)\end{array}$ \\
\hline Data & IDBR & $\mathrm{ABI} / \mathrm{ABS}$ & $\mathrm{ABI} / \mathrm{ABS}$ & $\mathrm{ABI} / \mathrm{ABS}$ & $\mathrm{ABI} / \mathrm{ABS}$ & ORBIS & ORBIS & $\mathrm{ABI} / \mathrm{ABS}$ & $\mathrm{ABI} / \mathrm{ABS}$ & $\mathrm{ABI} / \mathrm{ABS}$ & IDBR \\
\hline $\begin{array}{l}\text { Observatio } \\
\text { ns }\end{array}$ & $9,716,577$ & 119,691 & 114,883 & 117,420 & 71,329 & 99,149 & 96,138 & 117,420 & 71,329 & 71,231 & $4,597,208$ \\
\hline
\end{tabular}

Note: OLS estimates with standard errors clustered by firm in parentheses; *** indicates significance at the $1 \%, * * 5 \%$ and $* 10 \%$ level. We regress the logarithm of firm-level characteristics on the logarithm of the firm's repayment probability at the one-year horizon estimated using data at $t$ - 1 . The size of the individual regression samples is determined by data availability and is indicated in each table. Both panels do not condition on non-missing values on all the dependent variables (see Table A3 for conditioning on a common sample). Panel B conditions on individual sub-samples with at least two firm-level observations (in order to be able to include firm fixed effects). The time period is 2005 to 2013. Industry and year dummies are included in all models. Predicted PDs are not used in column (11). 
Table 3: The effect of credit frictions on aggregate output - Baseline results, full sample

\begin{tabular}{|c|c|c|c|c|c|c|c|c|}
\hline & (1) & (2) & (3) & (4) & (5) & (6) & (7) & (8) \\
\hline & Observations & \multicolumn{3}{|c|}{ Overall } & \multicolumn{2}{|c|}{ Scale } & \multicolumn{2}{|c|}{ TFP } \\
\hline & & $\Theta_{t}$ & $\begin{array}{c}\text { Percentage } \\
\text { loss of output }\end{array}$ & $\begin{array}{c}\text { Growth } \\
\text { contribution }\end{array}$ & $\Theta_{t}^{S}$ & $\begin{array}{c}\text { Percentage } \\
\text { loss of output }\end{array}$ & $\Theta_{t}^{T}$ & $\begin{array}{c}\text { Percentage } \\
\text { loss of output }\end{array}$ \\
\hline 2005 & $1,377,733$ & 0.211 & 27.731 & & 0.233 & 25.924 & 0.903 & 1.807 \\
\hline 2006 & $1,414,221$ & 0.230 & 26.363 & 1.875 & 0.255 & 24.520 & 0.902 & 1.843 \\
\hline 2007 & $1,460,639$ & 0.236 & 25.989 & 0.507 & 0.262 & 24.126 & 0.902 & 1.863 \\
\hline 2008 & $1,545,919$ & 0.242 & 25.632 & 0.481 & 0.267 & 23.811 & 0.904 & 1.821 \\
\hline 2009 & $1,480,481$ & 0.192 & 29.102 & -4.779 & 0.216 & 27.028 & 0.889 & 2.074 \\
\hline 2010 & $1,459,680$ & 0.201 & 28.412 & 0.969 & 0.226 & 26.380 & 0.892 & 2.032 \\
\hline 2011 & $1,502,427$ & 0.203 & 28.300 & 0.156 & 0.230 & 26.042 & 0.880 & 2.259 \\
\hline 2012 & $1,502,665$ & 0.204 & 28.197 & 0.144 & 0.231 & 25.970 & 0.882 & 2.227 \\
\hline 2013 & $1,569,340$ & 0.205 & 28.151 & 0.063 & 0.232 & 25.969 & 0.884 & 2.183 \\
\hline Average & $1,479,234$ & 0.214 & 27.542 & -0.073 & 0.239 & 25.530 & 0.893 & 2.012 \\
\hline
\end{tabular}

Notes: This table uses the full IDBR sample (See Table 1). $\Theta_{t}$ is the estimate of aggregate credit market frictions derived in Equation (18). Output loss is the proportionate fall in output as a result of credit frictions calculated using Equation (20). $\Theta_{t}^{S}$ is the scale component defined in Equation (22) and $\Theta_{t}^{T}$ is the TFP component defined in Equation (23). 
Table 4: The effect of credit frictions on aggregate output: broken down by firm size

\begin{tabular}{|c|c|c|c|c|c|c|c|c|c|c|c|c|}
\hline & \multicolumn{6}{|c|}{ SMEs } & \multicolumn{6}{|c|}{ LARGE FIRMS } \\
\hline & \multicolumn{2}{|c|}{ Overall } & \multicolumn{2}{|c|}{ Scale } & \multicolumn{2}{|c|}{ TFP } & \multicolumn{2}{|c|}{ Overall } & \multicolumn{2}{|c|}{ Scale } & \multicolumn{2}{|c|}{ TFP } \\
\hline & $\begin{array}{c}(1) \\
\text { Theta } \\
\Theta_{t}\end{array}$ & $\begin{array}{c}\text { (2) } \\
\% \text { loss } \\
\text { of output }\end{array}$ & $\begin{array}{c}(3) \\
\text { Theta } \\
\Theta_{t}^{S} \\
\end{array}$ & $\begin{array}{c}\text { (4) } \\
\% \text { loss } \\
\text { of output }\end{array}$ & $\begin{array}{c}\text { (5) } \\
\text { Theta } \\
\Theta_{t}^{T} \\
\end{array}$ & $\begin{array}{c}\text { (6) } \\
\% \text { loss } \\
\text { of output }\end{array}$ & $\begin{array}{c}(7) \\
\text { Theta } \\
\Theta_{t}\end{array}$ & $\begin{array}{c}\text { (8) } \\
\% \text { loss } \\
\text { of output }\end{array}$ & $\begin{array}{c}\text { (9) } \\
\text { Theta } \\
\Theta_{t}^{S} \\
\end{array}$ & $\begin{array}{c}\text { (10) } \\
\% \text { loss } \\
\text { of output }\end{array}$ & $\begin{array}{c}\text { (11) } \\
\text { Theta } \\
\Theta_{t}^{T} \\
\end{array}$ & $\begin{array}{c}\text { (12) } \\
\% \text { loss } \\
\text { of output }\end{array}$ \\
\hline 2005 & 0.155 & 32.159 & 0.173 & 30.298 & 0.898 & 1.861 & 0.319 & 21.220 & 0.344 & 19.817 & 0.927 & 1.403 \\
\hline 2006 & 0.170 & 30.847 & 0.191 & 28.881 & 0.893 & 1.966 & 0.354 & 19.477 & 0.380 & 18.144 & 0.931 & 1.333 \\
\hline 2007 & 0.176 & 30.400 & 0.197 & 28.385 & 0.891 & 2.015 & 0.357 & 19.317 & 0.384 & 17.949 & 0.930 & 1.368 \\
\hline 2008 & 0.180 & 30.030 & 0.203 & 27.922 & 0.887 & 2.108 & 0.354 & 19.445 & 0.380 & 18.155 & 0.934 & 1.290 \\
\hline 2009 & 0.132 & 34.471 & 0.151 & 32.179 & 0.874 & 2.292 & 0.316 & 21.329 & 0.343 & 19.851 & 0.923 & 1.478 \\
\hline 2010 & 0.132 & 34.451 & 0.151 & 32.142 & 0.873 & 2.309 & 0.351 & 19.598 & 0.377 & 18.253 & 0.931 & 1.345 \\
\hline 2011 & 0.147 & 32.912 & 0.169 & 30.591 & 0.874 & 2.321 & 0.322 & 21.060 & 0.353 & 19.327 & 0.911 & 1.733 \\
\hline 2012 & 0.138 & 33.824 & 0.159 & 31.367 & 0.866 & 2.457 & 0.345 & 19.879 & 0.376 & 18.290 & 0.919 & 1.588 \\
\hline 2013 & 0.130 & 34.639 & 0.150 & 32.175 & 0.865 & 2.463 & 0.364 & 19.000 & 0.394 & 17.493 & 0.923 & 1.507 \\
\hline Average & 0.151 & 32.637 & 0.172 & 30.438 & 0.880 & 2.199 & 0.343 & 20.036 & 0.370 & 18.587 & 0.925 & 1.449 \\
\hline
\end{tabular}

Notes: This table uses the full IDBR sample but estimates are broken down by firm size (See Table 1). SMEs have under 250 employees, large firms have 250 employees or more. $\Theta_{t}$ is the estimate of aggregate credit market frictions derived in Equation (18). Output loss is the proportionate fall in output as a result of credit frictions calculated using Equation (20). $\Theta_{t}^{S}$ is the scale component defined in Equation (22) and $\Theta_{t}^{T}$ is the TFP component defined in Equation (23). Appendix B2 gives details on how $\Theta_{t}$ (and similarly $\Theta_{t}^{S}$ and $\Theta_{t}^{T}$ ) is decomposed into an SME and a large firm component. Columns (1) through (6) are for SMEs and Columns (7) through (12) are for large firms. 
Table 5: The effect of credit frictions on aggregate output in manufacturing (ABI/ABS): Our method compared with the Standard Approach

\begin{tabular}{|c|c|c|c|c|c|c|c|c|c|c|c|c|c|}
\hline & \multirow[b]{3}{*}{$\begin{array}{l}\text { (1) } \\
\text { Obs }\end{array}$} & \multicolumn{6}{|c|}{ Baseline method } & \multicolumn{6}{|c|}{ Standard Approach: using measures of capital stock } \\
\hline & & \multicolumn{2}{|c|}{ Overall } & \multicolumn{2}{|c|}{ Scale } & \multicolumn{2}{|c|}{ TFP } & \multicolumn{2}{|c|}{ Overall } & \multicolumn{2}{|c|}{ Scale } & \multicolumn{2}{|c|}{ TFP } \\
\hline & & $\begin{array}{c}(2) \\
\text { Theta } \\
\Theta_{t} \\
\end{array}$ & $\begin{array}{c}\text { (3) } \\
\% \text { loss }\end{array}$ & $\begin{array}{c}\text { (4) } \\
\text { Theta } \\
\Theta_{t}^{S} \\
\end{array}$ & $\begin{array}{c}\text { (5) } \\
\% \text { loss }\end{array}$ & $\begin{array}{c}\text { (6) } \\
\text { Theta } \\
\Theta_{t}^{T} \\
\end{array}$ & $\begin{array}{c}(7) \\
\% \text { loss }\end{array}$ & $\begin{array}{c}\mathbf{( 8 )} \\
\text { Theta } \\
\Theta_{t} \\
\end{array}$ & $\begin{array}{c}(9) \\
\% \text { loss }\end{array}$ & $\begin{array}{c}\mathbf{( 1 0 )} \\
\text { Theta } \\
\Theta_{t}^{S} \\
\end{array}$ & $\begin{array}{c}(11) \\
\% \text { loss }\end{array}$ & $\begin{array}{c}\text { (12) } \\
\text { Theta } \\
\Theta_{t}^{T} \\
\end{array}$ & $\begin{array}{c}\text { (13) } \\
\% \text { loss }\end{array}$ \\
\hline 2005 & 8,295 & 0.215 & 27.393 & 0.239 & 25.524 & 0.901 & 1.868 & 0.019 & 56.253 & 0.025 & 52.422 & 0.763 & 3.831 \\
\hline 2006 & 7,533 & 0.239 & 25.768 & 0.264 & 23.975 & 0.905 & 1.792 & 0.013 & 59.429 & 0.017 & 55.748 & 0.765 & 3.681 \\
\hline 2007 & 8,159 & 0.256 & 24.738 & 0.283 & 22.897 & 0.904 & 1.841 & 0.009 & 62.907 & 0.013 & 57.073 & 0.643 & 5.834 \\
\hline 2008 & 4,987 & 0.247 & 25.317 & 0.273 & 23.451 & 0.902 & 1.866 & 0.005 & 66.613 & 0.008 & 60.654 & 0.625 & 5.959 \\
\hline 2009 & 4,907 & 0.216 & 27.374 & 0.242 & 25.325 & 0.892 & 2.048 & 0.004 & 69.213 & 0.005 & 63.804 & 0.643 & 5.410 \\
\hline 2010 & 5,306 & 0.240 & 25.753 & 0.267 & 23.800 & 0.897 & 1.953 & 0.005 & 67.574 & 0.006 & 63.193 & 0.705 & 4.381 \\
\hline 2011 & 4,975 & 0.258 & 24.598 & 0.287 & 22.666 & 0.899 & 1.932 & 0.006 & 65.764 & 0.009 & 60.268 & 0.651 & 5.496 \\
\hline 2012 & 5,086 & 0.237 & 25.933 & 0.266 & 23.879 & 0.892 & 2.054 & 0.005 & 67.104 & 0.008 & 61.450 & 0.638 & 5.654 \\
\hline 2013 & 4,801 & 0.238 & 25.849 & 0.268 & 23.736 & 0.889 & 2.113 & 0.006 & 65.303 & 0.009 & 60.287 & 0.677 & 5.016 \\
\hline Average & 6,005 & 0.238 & 25.858 & 0.266 & 23.917 & 0.898 & 1.941 & 0.008 & 64.462 & 0.011 & 59.433 & 0.679 & 5.029 \\
\hline
\end{tabular}

Notes: This table uses the ABI/ABS sample for the manufacturing sector only. Columns (2)-(7) use our method for measuring credit frictions with firm-level default risk. In columns (8)-(13) capital distortions are measured using the "standard" misallocation approach of Equation (34), which relies on empirical measures of capital and value added (construction of firm-level capital stocks is described in Appendix A4). Capital wedges are winsorized at the 1st and 99th percentiles by year. $\Theta_{t}$ is the estimate of aggregate credit market frictions derived in Equation (18). Output loss is the proportionate fall in output as a result of credit frictions calculated using Equation (20). $\Theta_{t}^{S}$ is the scale component defined in Equation (22) and $\Theta_{t}^{T}$ is the TFP component defined in Equation (23). Manufacturing corresponds to Section D SIC 1992. 


\section{A Online Data Appendix}

\section{A.1 Business Register Populations: IDBR Market Sec- tor}

The Inter-Departmental Business Register (IDBR) is a list of all UK incorporated businesses and other businesses registered for tax purposes. It does not include the crop and animal production part of agriculture, public administration and defence, activities of households as employers; undifferentiated goods and services-producing activities of households for own use, and activities of extraterritorial organizations and bodies. The IDBR is maintained by the Office for National Statistics (ONS, UK Census Bureau) and is the basis for almost all government business surveys as the best up to date snapshot of the enterprise and establishment population. The IDBR contains basic information for all businesses such as employment, industry and zip code. The IDBR is available at the "local unit" level. A local unit is a distinct economic unit in a defined geographical site, in other words a plant in manufacturing or a store in retail services. Local units are grouped into "reporting units" which we define as a firm in our study. In most cases, the reporting unit is the same as an "enterprise", defined by the ONS as "the smallest combination of legal units, which have a certain degree of autonomy within an enterprise group". ${ }^{40}$ IDBR is a continuous rolling business register. It is essentially the population of employer firms and is analogous to the U.S. Longitudinal Business Database. The IDBR is not provided directly to researchers. However, a snapshot of the IDBR is taken each year by the ONS and used as the sampling frame for various surveys, including the ABI/ABS. We reconstruct this annual sampling frame by merging the files that contain the identity of the firms (reporting units) that were surveyed for the ABI/ABS and responded, and those that were either not selected for the survey or were selected but failed to respond.

We focus on the market sector which includes an average of 1.5 million firms and around 16 million workers per year (see Table 1). It includes the following sectors in the ABI (SIC 1992 or 2003 sections): D Manufacturing, F Construction, G Wholesale and retail trade; repair of motor vehicles, motorcycles and personal and household goods, H Hotels and restaurants, I Transport, storage and communication, and $\mathrm{K}$ real estate, renting and business activities (but excluding real estate SIC 2-digit 70). Sectors we cover in the ABS (SIC 2007 sections) are: C Manufacturing, F Construction, G Wholesale and retail trade; repair of motor vehicles and motorcycles, $\mathrm{H}$ Transport and storage, I Accommodation and food service activities, J Information and communication, M Professional, Scientific and Technical Activities, N Administrative and Support Service Activities. Our sectoral coverage is com-

\footnotetext{
${ }^{40} \mathrm{~A}$ small number of large enterprises with a more complex structure have several reporting units.
} 
parable to that of Riley et al (2015). The sectors we drop are those where output is hard to measure, namely: financial services, non-market service sectors (e.g. education, health, social work and the public sector), agriculture, mining and quarrying, utilities, real estate, and non-profit organizations.

\section{A.2 Productivity Sub-sample: ABI/ABS data}

The Annual Business Survey (ABS) is the main survey of the UK nonfinancial business economy conducted by the Office for National Statistics (ONS). Until 2008, the ABS was known as the Annual Business Inquiry (ABI). ABI/ABS includes a rich set of variables that have been used to calculate UK productivity statistics including gross output, value added, labor, capital investment, intermediate inputs (of goods and, unlike the U.S. Census of Manufactures, service inputs) and wage bills.

The surveys are a census of large businesses (those with over $250 \mathrm{em}$ ployees) and a stratified random sample of smaller businesses. Large firms are therefore over-represented and sampling weights must be used to reflect aggregate developments. For this purpose, the ABI/ABS contains grossing weights which reflect the survey design. Groups of reporting units (sampling cells) are defined by three strata: employment size band, industry, and geographical region. We use a combination of probability weights (the inverse of the sampling probability) and employment weights provided by the ONS. Denote with $N_{p i}$ the number of firms in the population in sampling cell $i, N_{s i}$ the number of firms surveyed in sampling cell $i, E_{p i}$ average employment in the population in sampling cell $i$, and $E_{s i}$ average employment in the sample in sampling cell $i$. Using the ONS weights, total GVA in cell $i$ is then:

$$
\sum_{n=1}^{N_{s i}} G V A_{n} \frac{N_{p i}}{N_{s i}} \frac{E_{p i}}{E_{s i}}
$$

These are the weights we use when we work with the ABI/ABS full sample, e.g. in Table A4. In a few instances, we have to work with a sub-sample of the ABI/ABS. Specifically, we condition on non-missing data on real value added, the wage bill, and a capital stock estimate when we compare our approach to the standard misallocation approach (Table 5), include labor market frictions (Table A5), or use Solow residuals (Table A9). When we work with smaller samples, we adjust the ONS weights above to reflect extra selection and ensure that the sample is representative of the market sector as a whole. In grossing up the ONS weights, sampling strata are defined in terms of industry (SIC 1992 and SIC 2007 at the 4-digit level) and employment size bands $(1-9 ; 10-19 ; 20-49 ; 50-99 ; 100-249 ; 250$ or more). As other researchers before us, we ignore regions in defining the sampling strata due to small cell sizes. 
We define labor productivity as real value added per employee. Nominal value added (at market prices) and the wage bill are deflated using implied GVA deflators from the ONS.

\section{A.3 Data on Default Probabilities}

We use Bureau Van Dijk's Orbis database to obtain data for the inputs required by Standard and Poor's PD Model. Orbis is a worldwide digital database of the accounts of publicly and privately traded firms. We select all active and inactive UK firms from this database from 2005 to 2013.

Standard and Poor's widely used PD Model is an algorithm which takes accounting items and generates a risk score (called "implied credit worthiness") for each firm in each year. A risk score is expressed using S\&P's traditional rating symbols ('triple $\mathrm{A}$ ' $=\mathrm{AAA}$, 'triple $\mathrm{B}$ ' = BBB, etc.). There are 21 risk categories, from AAA to C. Apart from industry, year and public/private status, there are 19 items potentially used by the algorithm. These are total revenue, total equity, EBIT (operating income), income tax expense, interest expense, total revenue in the previous year, cash flow from operation, net property plant and equipment (fixed assets), retained earnings, total assets, cash and short-term investments, current liabilities, total debt, total liabilities, net income (P\&L), earnings from continuing operations, total depreciation and amortization, total deferred taxes, and other non cash items. The exact list of inputs depends on the public/private status of the firms and the broad sector in which they operate (manufacturing, services, infrastructure).

The actual default rates used by PD Model are averages by risk category which incorporate a long history of observed defaults up to the present (S\&P's CreditPro). Since we are interested in the historical perception of default probabilities, i.e. the probability of default as perceived at the time of the financial accounts data, we only use past (and not future) aggregate default information. For example, to calculate the expected one year ahead default probability in 2006 we use the 2006 risk scores combined with aggregate default rates from 1980 through 2006 and no data from 2007 or after.

Not all of these accounting items are needed to give a firm a risk score, however. For public firms total equity is required and for private firms we require either total revenue or (if this is missing) the four items: fixed assets, total assets, current liabilities, total liabilities. This generates a risk score for $95 \%$ of the 16,621,924 firm-year observations. We therefore have a total of $15,759,528$ observations for the period 2005-2013.

Note that bankruptcy and full exit from the market represent a minority of all defaults. The PD Model takes into account a variety of "default events", for example if a firm is unlikely to pay its credit obligations to the banking group in full or if the firm is past due more than 90 days on any material credit obligation. Elements taken as indications of unlikeliness to pay include if the bank consents to a distressed restructuring of the credit obligation; the 
bank sells the credit obligation at a material credit-related economic loss or the firm has been placed in bankruptcy.

The next step is to match the data on risk scores and accounting information from Orbis to the IDBR and the ABI/ABS surveys. BvD Orbis provides us with Company Registration Numbers (CRNs) that can be matched to the IDBR business register using the identification codes for enterprise units (entrefs). To respect confidentiality rules, this linking process was performed by the UK Data Service. Our IDBR panel is at the level of reporting units (rurefs), so the final step is to match the reporting units to their respective entrefs using a lookup table provided by the ONS.

There are several issues with this multi-step matching process that lead to imperfect match rates. In other words, there will be firms for which we do not have a risk score. First, some of the IDBR firms might be branches of foreign multinationals rather than wholly owned subsidiaries, so will not appear in the UK Orbis dataset, but will appear in the IDBR as reporting units. Second, some firms in Orbis do not have the necessary inputs to calculate a risk score. Third, Orbis has incomplete coverage of smaller firms (hence the better match rate with the $\mathrm{ABI} / \mathrm{ABS}$ as these are skewed towards larger firms). Fourth, the UK Data Service is not able to match all the CRNs to an enterprise unit. The CRN and IDBR systems are maintained independently, hence the same business is sometimes represented differently in either register. The IDBR identifies business units according to functional units, which are relevant for the computing of government statistics. A CRN number is created whenever a company's management registers a new business name. Hence there is no necessary one-to-one concordance between entrefs and CRNs. Finally, we are unable to match some reporting units to their entrefs for a similar reason, namely the ONS provided us with an entref-ruref concordance table which is a snapshot taken in 2013.

The UK Data Service was able to match 2,372,326 CRNs to an entref, representing 12,282,574 entref-year observations. From these, we drop observations with consolidation code $\mathrm{C} 2$ (consolidated accounts of a companyheadquarter that also has unconsolidated accounts) to avoid double counting as in Kalemli-Ozcan et al (2015) (81,354 matches). Although the majority of CRNs are matched to a single entref (and hence risk score), some CRNs are matched to the same enterprise reference number. This creates 463,726 entref-year duplicates. For these entrefs, we compute a weighted average risk score using weights based on the total assets of the individual CRNs that belong to the entref. Duplicate groups with insufficient data on total assets to calculate the weights are dropped entirely. We also sum up accounting items (e.g. total assets) at the entref level for those entrefs with multiple CRNs.

The next step is to match the risk scores and accounting data at the entref-year level to our IDBR panel, constructed using the ABI/ABS annual sampling frame. Our IDBR panel is at the ruref-year level. We therefore match the rurefs to their corresponding entrefs using a lookup table provided 
by the ONS (2013 vintage). We were able to match 7,175,770 observations to the IDBR. Although the majority of reporting units correspond to a single enterprise reference number, there are rurefs that belong to the same entref. In these cases, each ruref is assigned the risk score of its entref, and the accounting items are allocated to each ruref based on the latter's share of employment in total entref employment. This leaves us with $6,137,335$ missing values for risk scores. Our baseline approach to dealing with missing risk scores is to predict them using data on employment, age, industry (3-digits) and year. Employment, age, and industry are also interacted with the year dummies. For the $\mathrm{ABI} / \mathrm{ABS}$, we experimented with predicting missing risk scores using other data, e.g. on value added, in addition to industry, age, and employment, and found very robust results (not reported). Importantly, as discussed in the text all our results are robust to working solely with the non-imputed data. Whenever we use these smaller samples, we construct our own set of sampling weights in order to capture aggregate developments. Finally, the risk scores are matched to historical default rates using data from S\&P's CreditPro.

Table A2 gives an overview of the match rates. Column (1) reports the number of firms in the IDBR (our core sample) and Column (2) reports the number of firms in the IDBR for which we were able to match a risk score. Column (1) shows that we have 1.5 million firms per year on average in the IDBR and we match $54 \%$ of these (almost 800,000 firms) to risk scores as shown in Columns (2) and (3). Column (4) shows that we have 37,573 firms per year on average in the ABI/ABS, $70 \%$ of which can be matched with a risk score on average (Column (6)). The higher match rate compared to Column (3) is mainly because it is harder to match smaller firms and the $\mathrm{ABI} / \mathrm{ABS}$ is dominated by large firms due to its sample design. Reassuringly, the non-imputed IDBR sample covers on average $74 \%$ of annual aggregate employment because firms with missing risk scores tend to be very small, which is why imputing missing scores makes little difference to the aggregate results. In the paper we show extensive robustness tests, including showing that dropping all the imputed default probabilities makes little difference to our results, mainly because the non-matched firms are relatively small and only make a minor contribution to the aggregate losses.

As discussed in the text, we tabulate the average default probabilities by risk score and year in Table A1 and plot the risk score densities in Figure 2 for the IDBR matched sample. Although there are 21 risk score categories, we bin these into 15 categories for disclosure purposes. There has been a clear shift to the right in the mass of risk scores (firms' default probabilities have increased), which started in the Great Recession. 


\section{A.4 Capital Stock Calculation and Perpetual Inven- tory Method}

We apply the Perpetual Inventory Method (PIM) on establishment-level data from the ABI/ABS surveys. This is the standard way in which the ONS calculates establishment-level capital stocks and we follow their procedures as closely as possible. The PIM is:

$$
K_{n t}=(1-\delta) K_{n t-1}+I_{n t}
$$

where $K_{n t}$ is establishment $n$ 's capital stock at the beginning of period $t$, $K_{n t-1}$ is the capital stock at the beginning of period $t-1, I_{n t}$ is real net investment (capital expenditure minus proceeds from disposal of capital) deflated by an industry specific deflator, and $\delta$ is the depreciation rate. We allow for three types of investment: Plant and Machinery, Buildings, and Vehicles with depreciation rates of $8 \% ; 2 \%$ and $20 \%$ respectively. We do a separate PIM calculation for each type of capital, then sum them to obtain the total capital stock in every period.

Although our sample starts in 2005 we have ABI/ABS data back to 1979 for manufacturing which we can use for the PIM. However, small establishments are not sampled every year. Because the ABI/ABS is a stratified random sample there are gaps in the establishment's investment series making it hard to implement the PIM. Hence, we impute missing investment values using each establishment's average ratio of real net capital expenditures to employment (which is always available from the IDBR if the establishment is alive). The imputation of investment values will be more of a problem when there are many missing values. So we set a 'tolerance level', i.e. a maximum ratio of imputed to actual values. If we increase the tolerance level, we will get more establishments with capital stock data, but mismeasurement may worsen. In the baseline data set, we apply a ratio of 10 (so not more than 10 investment values are imputed for an establishment with only one valid investment number), but we change the tolerance level to check robustness.

We then need to impute an initial capital stock for entrants and for establishments that are sampled for the first time but are not genuine entrants (i.e. they were born before the year in which they were first sampled). To do so, we apportion to those establishments part of the aggregate industry-level capital stock. Our measure of aggregate industry-level capital stocks is the Volume Index of Capital Services (VICS) produced by the ONS. The VICS is a measure of capital input to economic production which takes account of the quality and use of the capital stock across time and different types of assets. VICS weights together the growth of the net stock of assets using a user cost of capital. The VICS data sets contain data on capital stocks, investment, and deflators at the industry level, by asset category. The apportioning procedure has two steps. First, the VICS is apportioned to the entire population of selected establishments in the sample based on their share of 
capital expenditures in the sectoral aggregates. The resulting capital stock is what we call 'selected capital'. Second, each establishment is allocated part of this selected capital based on its share of total purchases in the sectoral sample aggregate. Missing data on total purchases of goods and services are imputed using employment data and a firm's average ratio of total purchases to employment.

There are some observations with zero values of the capital stock after this procedure, for which we cannot calculate a valid TFP number using the Solow residual method (rather than our baseline method). Overall we lose 115,729 observations over the entire sample period 2005-2013 due to missing data on the capital stock, the wage bill, and value added.

\section{B Online Further Technical detail Appendix}

\section{B.1 Empirical factor shares and Solow residuals}

Given the production function

$$
Y_{n t}=\theta_{n t}\left(L_{n t}^{1-\alpha} K_{n t}^{\alpha}\right)^{\eta}
$$

the Solow residual is constructed in the standard way from:

$$
\ln \left(\theta_{n t}\right)=\ln \left(Y_{n t}\right)-\eta(1-\alpha) \ln \left(w_{t} L_{n t}\right)-\eta \alpha \ln \left(K_{n t}\right)
$$

where $Y_{n t}$ is real gross value added, $w_{t} L_{n t}$ is the wage bill (real labor costs instead of headcount) and $K_{n t}$ is the real capital stock estimated using the perpetual inventory method. In our baseline estimates, we set $\eta$ equal to 0.85 and $\alpha$ equal to $\frac{1}{3}$ across industries.

Because industries could in principle have different production technologies, we also estimate values of $\alpha$ using the empirical shares of labor costs in value added separately for each three-digit industry using ABI/ABS data. Abstracting from frictions in labor markets, the first order condition for employment generates that the labor share is:

$$
\frac{w_{t} L_{n t}}{Y_{n t}}=\eta(1-\alpha)
$$

We use the share of labor costs in value added in each three-digit industry in each year and average this between 2005 and 2013 to estimate $\eta(1-\alpha)$. As above, we set $\eta=0.85$ and recover an industry-specific estimate of $\alpha$. Note that although these are not directly relative to a time-varying industry average, the way TFP enters the formula for $\Theta_{t}$ is relative to industry means, so we are not making TFP comparisons across industries. In order to implement equation (20), we also estimate an aggregate $\alpha$ following the same procedure. The aggregate estimate stands at approximately 0.38 , slightly higher than our baseline of $\frac{1}{3}$. 


\section{B.2 Decomposing credit frictions by size}

Credit market frictions in industry $j$ at time $t$ are given by

$$
\Theta_{j t}=\sum_{n=1}^{N_{j t}} \omega_{n j t} \tau_{n j t}
$$

This can be re-written as the weighted sum of an SME component $\Theta_{j t S}$ and a large-firm component $\Theta_{j t L}$ as follows

$$
\begin{aligned}
\Theta_{j t} & =\lambda_{j t S} \Theta_{j t S}+\lambda_{j t L} \Theta_{j t L} \\
& =\left(\frac{\hat{\theta}_{j t S}}{\hat{\theta}_{j t}}\right)^{\frac{1}{1-\eta}} \sum_{n=1}^{N_{j t S}} \omega_{n j t S} \tau_{n j t}+\left(\frac{\hat{\theta}_{j t L}}{\hat{\theta}_{j t}}\right)^{\frac{1}{1-\eta}} \sum_{n=1}^{N_{j t L}} \omega_{n j t L} \tau_{n j t}
\end{aligned}
$$

where

- $N_{j t S}$ is the number of SMEs in industry $j, N_{j t L}$ the number of large firms in industry $j$, and $N_{j t}$ the total number of firms in industry $j$;

- $\lambda_{j t S}=\left(\frac{\hat{\theta}_{j t S}}{\hat{\theta}_{j t}}\right)^{\frac{1}{1-\eta}}$

- $\lambda_{j t L}=\left(\frac{\hat{\theta}_{j t L}}{\hat{\theta}_{j t}}\right)^{\frac{1}{1-\eta}}$;

- $\omega_{n j t S}=\left(\frac{\theta_{n j t}}{\hat{\theta}_{j t S}}\right)^{\frac{1}{1-\eta}}$ and $\hat{\theta}_{j t S}=\left(\sum_{n=1}^{N_{j t S}} \theta_{n j t^{\frac{1}{1-\eta}}}\right)^{1-\eta}$;

- $\omega_{n j t L}=\left(\frac{\theta_{n j t}}{\hat{\theta}_{j t L}}\right)^{\frac{1}{1-\eta}}$ and $\hat{\theta}_{j t L}=\left(\sum_{n=1}^{N_{j t L}} \theta_{n j t^{\frac{1}{1-\eta}}}\right)^{1-\eta}$;

- $\hat{\theta}_{j t}=\left(\sum_{n=1}^{N_{j}} \theta_{n j t^{\frac{1}{1-\eta}}}\right)^{1-\eta}$.

In this decomposition, the size-specific measures of credit market frictions, $\Theta_{j t S}$ and $\Theta_{j t L}$, are weighted by the relative aggregate productivity of each size category. As we did when estimating $\Theta_{t}$, we implement the size decomposition at the 3-digit industry level and then aggregate using industry employment shares by size category to obtain an aggregate estimate of credit frictions for SMEs and large firms separately. We use a similar decomposition to look at sectors (SIC 1992 divisions) in isolation. 


\section{B.3 Further Robustness Tests}

\section{B.3.1 Micro regressions of firm performance on default probabil-}

ities

Table 2 shows that firms with higher repayment probabilities have better performance outcomes in the future along a number of dimensions - employment, capital stock, investment flows (and intensities) and survival. These positive correlations are robust to a wide variety of checks. Table A3 replicates the analysis of Table 2 but conditions on a common sample where none of the relevant dependent variables are missing. The results are very similar. In addition, we used the level of the repayment probability instead of the logarithm; levels of the dependent variables instead of the logarithms, and experimented with less parametric approaches, all of which supported the positive correlations shown in Table 2 (not reported).

\section{B.3.2 Expected versus Realized Output}

Following the standard macro approach, our estimates of efficiency losses are based on realized output, but one could argue that they should be computed ex ante, i.e. before output is realized. For any given level of realized output, expected output is lower since each firm's output is multiplied by the probability that default does not occur. ${ }^{41}$ For any chosen benchmark, the deviation of expected output from its reference level is now given by $\frac{\hat{Y}_{t}^{e}-Y_{t}^{e}}{\hat{Y}_{t}^{e}}=1-\left[\frac{\Theta_{t}^{e}}{\hat{\Theta}_{t}^{e}}\right]^{\frac{1-\eta}{1-\alpha \eta}}$ where $\Theta_{t}^{e}=\sum_{n=1}^{N} \phi_{n t} \omega_{n t} \tau_{n t}$, is now used instead of equation (18). The results from this exercise are in Appendix Table A13. They show that an expected output benchmark implies that the estimates of output losses increase only marginally (from $27.5 \%$ in Table 3 to $28.5 \%$ in Table A13).

\section{Online Appendix: Productivity Trends}

Basic UK productivity trends (value added per worker) in the market economy are shown in Figure A1. Our aggregated ABI/ABS data is compared to the official "sectoral publications" from the ONS. ${ }^{42}$ The industry definitions cannot be compared precisely (see notes to Figure A1), but the overall trends are very similar. We also include a trend based on the average annual growth

\footnotetext{
${ }^{41}$ This does of course assume that default is associated with no output being produced.

42 "Sector publications" refer to estimates of aggregate labor productivity based on the sectoral figures (four-digit SIC) released publicly by the ONS for the sectors included in the sample (See ONS UK non-financial business economy Statistical bulletins).
} 
rate of output per worker (whole economy, seasonally adjusted) between 1979 and 2007. This shows the predicated path of output per worker according to the pre-crisis trend ( $2 \%$ per annum). There was a productivity gap of 11 percentage points by the end of 2013. Our model implies that we explain about a fifth of this gap. Indeed, had credit frictions stayed at their pre-crisis level of 2007, output would have been 2.16 percentage points higher in 2013 (28.2\% - 26\% in Column (3) of Table 3$)$.

The productivity decline was accompanied by a fall in business investment that was significantly larger than in previous recessions (Benito et al, 2010). It took until the third quarter of 2013 for business investment to reach its level in the second quarter of 2008 (Figure A2). There are many factors that could explain the decline in investment such as weak demand, pessimism over future TFP growth and uncertainty. But the financial crisis also led to restrictions in bank lending to non-financial corporations. Bank lending to the corporate sector in the UK continued to contract long after the acute phase of the credit crisis. While large firms can have recourse to other sources of finance, for instance by issuing bonds or equities, SMEs are more likely to be constrained. They are also more dependent on banks for their external finance. ${ }^{43}$ This is consistent with the heterogeneity we find between large and small firms.

A range of explanations have been put forward to explain weak productivity but work on the role of credit supply remains sparse. Franklin et al (2015) use financial statement data for a set of UK firms and information on the identity of firms' lenders in the pre-crisis period to identify the negative impact of the contraction in credit supply on labor productivity, wages and the capital intensity of production at the firm level. Using decomposition techniques to separate contributions to aggregate productivity of business restructuring and of productivity growth within firms, Barnett et al (2014a, 2014b) and Riley et al (2015) find that the within-firm component accounts for the vast majority of the fall in UK productivity. These papers also provide some evidence of reallocation being subdued during the crisis. Barnett et al (2014a) find that the contribution from reallocation declined in 2008-2009 and became negligible between 2010 and 2012, instead of increasing significantly as one would expect in a recession. They estimate that less efficient reallocation and a slowdown in creative destruction account for around one third of the fall in average annual productivity growth between 2002-7 and 2008-11. Similarly, Riley et al (2015) find that the growth contribution of both between-firm effects (changes in market share among continuing firms) and net entry were more subdued between 2007 and 2013 than between 1998 and 2007. Those two papers also provide some evidence of a weakening correlation between firms' financial health and their investment and employment behavior. Our contracting model of Section 2 suggests two main channels

\footnotetext{
${ }^{43}$ In 2010, only around $2 \%$ of SMEs used external equity as a source of finance (BIS, 2010). Armstrong et al (2013) show that SMEs have faced a very challenging environment for accessing credit after the financial crisis and during the subsequent recession.
} 
through which the financial crisis could have negatively affected default risk: lower asset values affecting collateral $(A)$ and weaker competition in banking leading to an increase in switching costs $(\kappa)$, which worsened borrowers' outside options. 


\section{Online Appendix Figures and Tables}

\section{FIGURE A1: Labor productivity in the "market sector" $(2007=100)$}

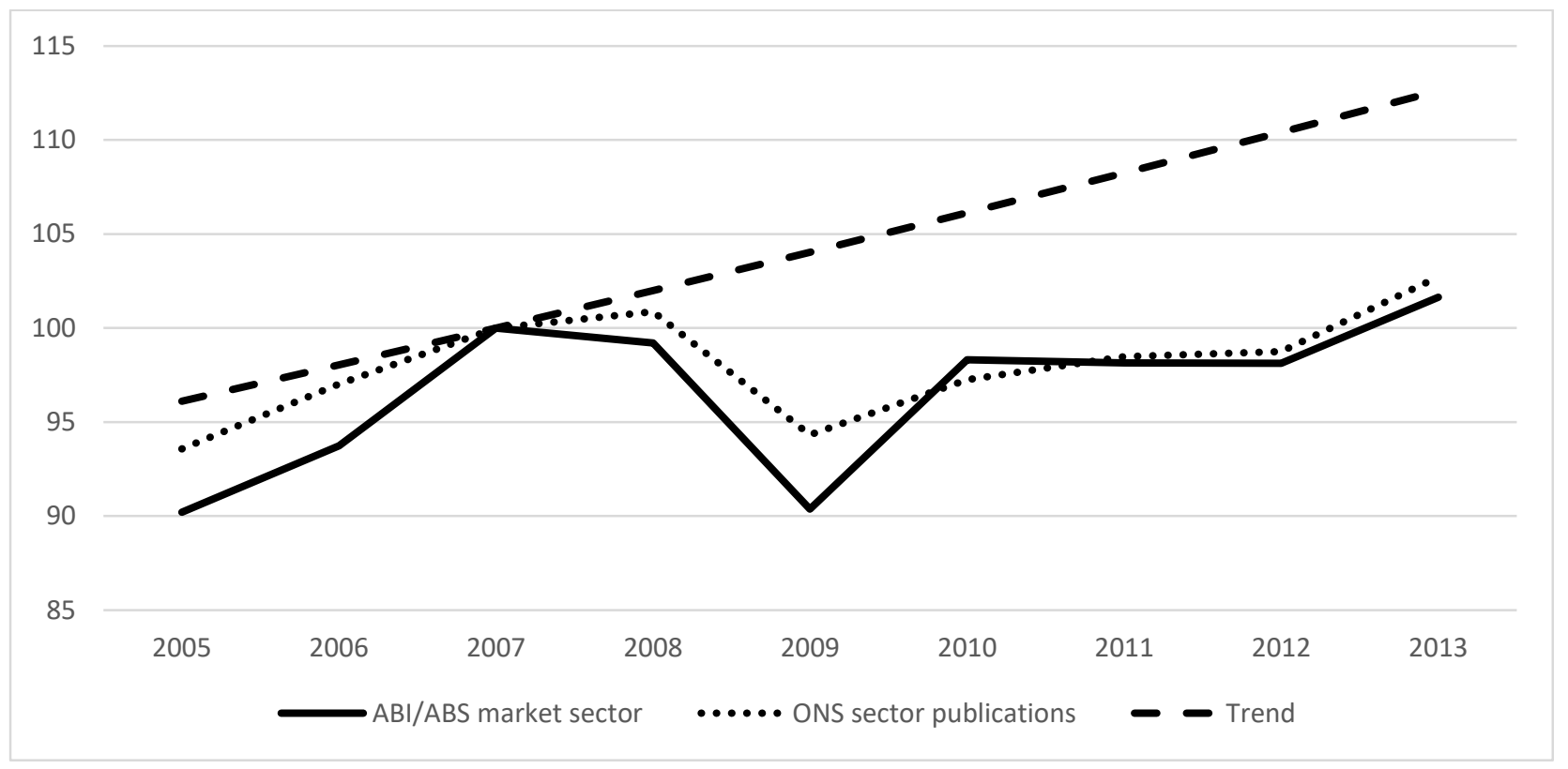

Notes: This graph shows labor productivity (real value added per employee) in the market sector in three distinct samples. The solid line is our ABI/ABS market sector sample, which includes all sectors in the ABI/ABS, except financial services, education, health, social work, agriculture, mining and quarrying, utilities, real estate, and non-profit organizations. The dotted line ("ONS sector publications") refers to productivity estimates based on the ONS UK nonfinancial business economy Statistical bulletins. Note that the sectoral publication numbers include the real estate sector (which we drop in our ABI/ABS sample) because it cannot be disentangled from the rest of SIC 1992 section K. The dashed line ("Trend") assumes a historical average growth of $2 \%$ per annum (the average annual growth rate of output per worker between 1979 and 2007). The "productivity gap" at the end of the period is $11 \%$ compared to trend. 


\section{FIGURE A2: Gross Fixed Capital Formation by UK businesses, 2008 Q2=100}

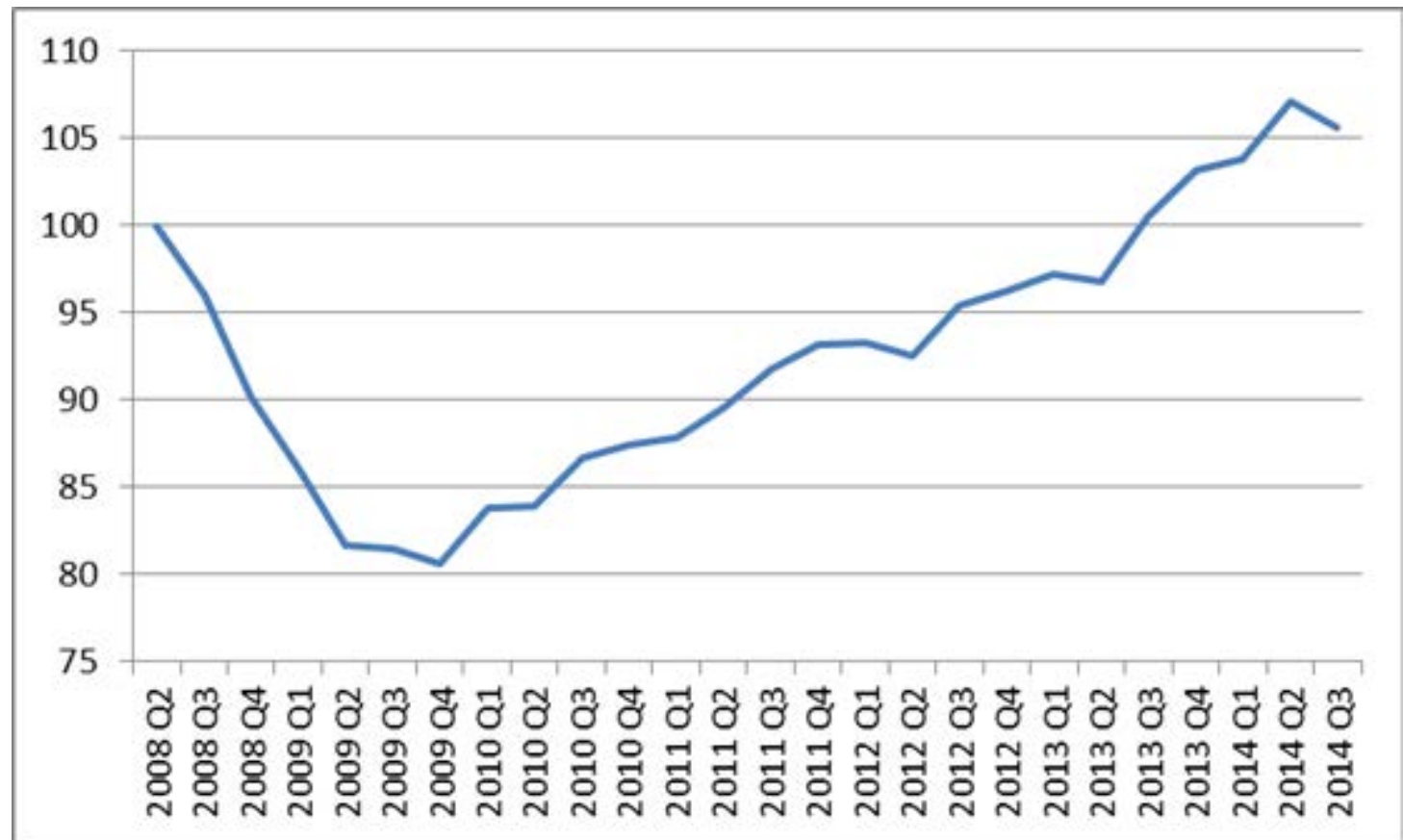

Source: ONS Statistical Bulletin, Business Investment, Q3 2014 Revised Results, 23 December 2014. Series Business Investment, Chained Volume Measure, seasonally adjusted. 
Table A1: Distribution of firms across risk bands, IDBR market sector

PANEL A: Average default probability per year and risk band (in \%)

\begin{tabular}{|c|c|c|c|c|c|c|c|c|c|c|c|c|c|c|c|}
\hline & 1 & 2 & 3 & 4 & 5 & 6 & 7 & 8 & 9 & 10 & 11 & 12 & 13 & 14 & 15 \\
\hline Risk band & AAA to A- & BBB+ & BBB & BBB- & BB+ & BB & BB- & B+ & B & B- & $\mathrm{CCC}+$ & $\mathrm{CCC}$ & CCC- & $\mathrm{CC}$ & C \\
\hline 2005 & 0.09 & 0.17 & 0.27 & 0.40 & 0.53 & 1.00 & 1.70 & 2.97 & 8.23 & 12.26 & 25.66 & 24.47 & 35.23 & 56.52 & 62.50 \\
\hline 2006 & 0.08 & 0.16 & 0.25 & 0.37 & 0.52 & 0.93 & 1.62 & 2.80 & 7.54 & 11.24 & 24.24 & 23.79 & 35.00 & 56.25 & 62.50 \\
\hline 2007 & 0.08 & 0.14 & 0.23 & 0.35 & 0.48 & 0.89 & 1.50 & 2.63 & 6.72 & 10.18 & 23.17 & 23.57 & 35.33 & 56.57 & 62.50 \\
\hline 2008 & 0.11 & 0.15 & 0.24 & 0.38 & 0.55 & 0.88 & 1.44 & 2.68 & 6.32 & 9.93 & 22.88 & 24.46 & 34.92 & 55.24 & 62.50 \\
\hline 2009 & 0.11 & 0.17 & 0.24 & 0.44 & 0.51 & 0.90 & 1.42 & 2.83 & 6.77 & 11.01 & 24.53 & 26.94 & 36.68 & 59.68 & 66.67 \\
\hline 2010 & 0.09 & 0.16 & 0.23 & 0.42 & 0.54 & 0.88 & 1.39 & 2.71 & 6.34 & 10.10 & 22.91 & 27.19 & 36.45 & 60.56 & 66.67 \\
\hline 2011 & 0.09 & 0.15 & 0.22 & 0.40 & 0.51 & 0.83 & 1.32 & 2.61 & 5.91 & 9.61 & 22.27 & 26.71 & 37.22 & 59.73 & 66.67 \\
\hline 2012 & 0.09 & 0.14 & 0.20 & 0.38 & 0.48 & 0.79 & 1.29 & 2.52 & 5.49 & 9.11 & 22.20 & 26.64 & 38.03 & 59.87 & 66.67 \\
\hline 2013 & 0.08 & 0.13 & 0.19 & 0.35 & 0.45 & 0.75 & 1.24 & 2.44 & 5.05 & 8.69 & 21.57 & 26.80 & 38.46 & 60.48 & 66.67 \\
\hline Average & 0.09 & 0.15 & 0.23 & 0.39 & 0.51 & 0.87 & 1.44 & 2.69 & 6.49 & 10.24 & 23.27 & 25.62 & 36.37 & 58.32 & 64.82 \\
\hline
\end{tabular}

PANEL B: Number of observations per year and risk band

\begin{tabular}{l|cccccccccccccccccc}
\hline \hline & $\mathbf{1}$ & $\mathbf{2}$ & $\mathbf{3}$ & $\mathbf{4}$ & $\mathbf{5}$ & $\mathbf{6}$ & $\mathbf{7}$ & $\mathbf{8}$ & $\mathbf{9}$ & $\mathbf{1 0}$ & $\mathbf{1 1}$ & $\mathbf{1 2}$ & $\mathbf{1 3}$ & $\mathbf{1 4}$ & $\mathbf{1 5}$ \\
\hline Risk band & AAA to A- & $\mathbf{B B B}+$ & $\mathbf{B B B}$ & $\mathbf{B B B}-$ & $\mathbf{B B}+$ & $\mathbf{B B}$ & $\mathbf{B B}-$ & $\mathbf{B}+$ & $\mathbf{B}$ & $\mathbf{B}-$ & $\mathbf{C C C}+$ & $\mathbf{C C C}$ & $\mathbf{C C C}-$ & $\mathbf{C C}$ & $\mathbf{C}$ \\
\hline $\mathbf{2 0 0 5}$ & 51 & 437 & 2,130 & 7,300 & 22,216 & 44,686 & 71,518 & 110,536 & 491,054 & 412,138 & 78,487 & 76,731 & 47,565 & 11,008 & 1,876 \\
$\mathbf{2 0 0 6}$ & 59 & 542 & 2,469 & 8,803 & 28,007 & 58,021 & 89,178 & 169,146 & 561,741 & 290,920 & 82,998 & 67,750 & 38,016 & 14,252 & 2,319 \\
$\mathbf{2 0 0 7}$ & 66 & 572 & 2,512 & 9,230 & 28,567 & 57,965 & 95,048 & 172,139 & 531,577 & 341,639 & 89,748 & 72,089 & 43,356 & 13,713 & 2,418 \\
$\mathbf{2 0 0 8}$ & 124 & 962 & 4,331 & 20,125 & 42,346 & 73,289 & 101,530 & 263,243 & 534,665 & 275,764 & 99,941 & 70,974 & 42,092 & 14,002 & 2,531 \\
$\mathbf{2 0 0 9}$ & 63 & 704 & 3,006 & 8,858 & 25,461 & 48,635 & 80,552 & 126,609 & 398,800 & 452,172 & 161,567 & 92,545 & 64,371 & 14,629 & 2,509 \\
$\mathbf{2 0 1 0}$ & 77 & 652 & 2,707 & 8,506 & 22,767 & 42,284 & 71,311 & 110,083 & 346,569 & 486,557 & 178,452 & 100,454 & 71,720 & 14,999 & 2,542 \\
$\mathbf{2 0 1 1}$ & 94 & 864 & 3,944 & 11,079 & 28,769 & 54,677 & 91,129 & 140,844 & 411,996 & 418,351 & 161,243 & 100,577 & 65,310 & 11,627 & 1,923 \\
$\mathbf{2 0 1 2}$ & 115 & 820 & 3,905 & 11,321 & 28,426 & 50,792 & 84,473 & 128,667 & 361,759 & 454,520 & 179,054 & 109,775 & 73,647 & 13,378 & 2,013 \\
$\mathbf{2 0 1 3}$ & 92 & 746 & 2,495 & 7,753 & 23,010 & 45,749 & 71,849 & 102,883 & 275,534 & 554,285 & 249,546 & 130,399 & 85,913 & 15,114 & 3,972 \\
\hline Average & 82 & 700 & 3,055 & 10,331 & 27,730 & 52,900 & 84,065 & 147,128 & 434,855 & 409,594 & 142,337 & 91,255 & 59,110 & 13,636 & 2,456 \\
\hline \hline
\end{tabular}


PANEL C: Fraction of firms in each risk band (in \%)

\begin{tabular}{|c|c|c|c|c|c|c|c|c|c|c|c|c|c|c|c|}
\hline & 1 & 2 & 3 & 4 & 5 & 6 & 7 & 8 & 9 & 10 & 11 & 12 & 13 & 14 & 15 \\
\hline Risk band & AAA to A- & BBB + & BBB & BBB- & BB+ & BB & BB- & $\mathbf{B}+$ & B & B- & $\mathrm{CCC}+$ & $\mathrm{CCC}$ & CCC- & $\mathrm{CC}$ & $\mathrm{C}$ \\
\hline 2005 & 0.00 & 0.03 & 0.15 & 0.53 & 1.61 & 3.24 & 5.19 & 8.02 & 35.64 & 29.91 & 5.70 & 5.57 & 3.45 & 0.80 & 0.14 \\
\hline 2006 & 0.00 & 0.04 & 0.17 & 0.62 & 1.98 & 4.10 & 6.31 & 11.96 & 39.72 & 20.57 & 5.87 & 4.79 & 2.69 & 1.01 & 0.16 \\
\hline 2007 & 0.00 & 0.04 & 0.17 & 0.63 & 1.96 & 3.97 & 6.51 & 11.79 & 36.39 & 23.39 & 6.14 & 4.94 & 2.97 & 0.94 & 0.17 \\
\hline 2008 & 0.01 & 0.06 & 0.28 & 1.30 & 2.74 & 4.74 & 6.57 & 17.03 & 34.59 & 17.84 & 6.46 & 4.59 & 2.72 & 0.91 & 0.16 \\
\hline 2009 & 0.00 & 0.05 & 0.20 & 0.60 & 1.72 & 3.29 & 5.44 & 8.55 & 26.94 & 30.54 & 10.91 & 6.25 & 4.35 & 0.99 & 0.17 \\
\hline 2010 & 0.01 & 0.04 & 0.19 & 0.58 & 1.56 & 2.90 & 4.89 & 7.54 & 23.74 & 33.33 & 12.23 & 6.88 & 4.91 & 1.03 & 0.17 \\
\hline 2011 & 0.01 & 0.06 & 0.26 & 0.74 & 1.91 & 3.64 & 6.07 & 9.37 & 27.42 & 27.85 & 10.73 & 6.69 & 4.35 & 0.77 & 0.13 \\
\hline 2012 & 0.01 & 0.05 & 0.26 & 0.75 & 1.89 & 3.38 & 5.62 & 8.56 & 24.07 & 30.25 & 11.92 & 7.31 & 4.90 & 0.89 & 0.13 \\
\hline 2013 & 0.01 & 0.05 & 0.17 & 0.52 & 1.53 & 3.04 & 4.78 & 6.85 & 18.34 & 36.89 & 16.61 & 8.68 & 5.72 & 1.01 & 0.26 \\
\hline Average & 0.01 & 0.05 & 0.21 & 0.72 & 1.92 & 3.66 & 5.82 & 10.35 & 31.06 & 26.71 & 8.75 & 5.88 & 3.79 & 0.92 & 0.15 \\
\hline
\end{tabular}

Notes: These panels show some descriptive statistics by year and risk band. We group risk scores AAA to A- to adhere to the disclosure rules of the UK Data Service. Panel A shows the average default probability in each risk band by year. Panel B gives the number of observations underlying these PDs, and Panel C gives the fraction of firms in each risk band by year. All averages are unweighted (so are different from, say, Figure 1, which applies employment weights). 
Table A2: Match rates between IDBR, ABI/ABS and data on Probabilities of Default

\begin{tabular}{|c|c|c|c|c|c|c|}
\hline & $\begin{array}{c}\text { (1) } \\
\text { IDBR } \\
\text { \# firms }\end{array}$ & $\begin{array}{c}\text { (2) } \\
\text { Matched } \\
\text { with PDs } \\
\end{array}$ & $\begin{array}{c}\text { (3) } \\
\text { \% of non-imputed PDs in } \\
\text { IDBR } \\
\end{array}$ & $\begin{array}{c}\text { (4) } \\
\text { ABI/ABS } \\
\text { \#firms } \\
\end{array}$ & $\begin{array}{l}\text { (5) } \\
\text { Matched } \\
\text { with PDs } \\
\end{array}$ & $\begin{array}{c}\text { (6) } \\
\text { \% of non-imputed PDs in } \\
\text { ABI/ABS } \\
\end{array}$ \\
\hline 2005 & $1,377,733$ & 607,217 & 44.1 & 40,083 & 25,019 & 62.4 \\
\hline 2006 & $1,414,221$ & 688,641 & 48.7 & 33,742 & 22,659 & 67.2 \\
\hline 2007 & $1,460,639$ & 734,464 & 50.3 & 37,220 & 25,233 & 67.8 \\
\hline 2008 & $1,545,919$ & 785,836 & 50.8 & 39,365 & 27,361 & 69.5 \\
\hline 2009 & $1,480,481$ & 794,111 & 53.6 & 37,814 & 27,087 & 71.6 \\
\hline 2010 & $1,459,680$ & 813,333 & 55.7 & 38,123 & 26,336 & 69.1 \\
\hline 2011 & $1,502,427$ & 868,236 & 57.8 & 37,561 & 27,233 & 72.5 \\
\hline 2012 & $1,502,665$ & 910,875 & 60.6 & 37,644 & 28,243 & 75.0 \\
\hline 2013 & $1,569,340$ & 973,057 & 62.0 & 36,605 & 27,849 & 76.1 \\
\hline Average & $1,479,234$ & 797,308 & 53.7 & 37,573 & 26,336 & 70.1 \\
\hline
\end{tabular}

Notes: The samples are the IDBR (Columns (1) to (3)) and the ABI/ABS surveys (Columns (4) to (6)). We predict default probabilities for the missing values in order to use the full number of observations in Columns (1) and (4), but our results are robust to using the smaller samples in Columns (2) and (5), as we discuss in the text. 
Table A3: Firm performance and lagged repayment probabilities - Conditioning on the same sample across columns

PANEL A: Controls for industry and year fixed effects

\begin{tabular}{|c|c|c|c|c|c|c|c|c|c|c|c|}
\hline & (1) & (2) & (3) & (4) & (5) & (6) & (7) & (8) & (9) & (10) & (11) \\
\hline & $\begin{array}{c}\text { Ln(employ } \\
\text { ment) }\end{array}$ & $\begin{array}{c}\text { Ln(employ } \\
\text { ment) }\end{array}$ & $\begin{array}{c}\text { Ln(real } \\
\text { GVA) }\end{array}$ & $\begin{array}{l}\text { Ln(capital } \\
\text { stock) }\end{array}$ & $\begin{array}{l}\text { Ln(invest } \\
\text { ment) }\end{array}$ & $\begin{array}{c}\text { Ln(total } \\
\text { assets) }\end{array}$ & $\begin{array}{c}\text { Ln(fixed } \\
\text { assets) }\end{array}$ & $\begin{array}{c}\text { Ln(capital/ } \\
\text { labor) }\end{array}$ & $\begin{array}{c}\text { Ln(invest } \\
\text { ment/- } \\
\text { labor) }\end{array}$ & $\begin{array}{c}\text { Ln(invest } \\
\text { ment/- } \\
\text { capital ) }\end{array}$ & Survival \\
\hline $\begin{array}{l}\text { Ln(Repay } \\
\text { ment } \\
\text { prob.) }\end{array}$ & $\begin{array}{c}0.390 * * * \\
(0.004)\end{array}$ & $\begin{array}{c}1.574 * * * \\
(0.072)\end{array}$ & $\begin{array}{c}2.369^{* * * *} \\
(0.080)\end{array}$ & $\begin{array}{c}2.156^{* * * *} \\
(0.094)\end{array}$ & $\begin{array}{c}2.752 * * * \\
(0.102)\end{array}$ & $\begin{array}{c}2.930 * * * \\
(0.096)\end{array}$ & $\begin{array}{c}3.583 * * * \\
(0.111)\end{array}$ & $\begin{array}{c}0.647 * * * \\
(0.055)\end{array}$ & $\begin{array}{c}1.224 * * * \\
(0.064)\end{array}$ & $\begin{array}{c}0.572 * * * \\
(0.051)\end{array}$ & $\begin{array}{c}0.045 * * * \\
(0.001)\end{array}$ \\
\hline Data & IDBR & $\mathrm{ABI} / \mathrm{ABS}$ & $\mathrm{ABI} / \mathrm{ABS}$ & $\mathrm{ABI} / \mathrm{ABS}$ & $\mathrm{ABI} / \mathrm{ABS}$ & ORBIS & ORBIS & $\mathrm{ABI} / \mathrm{ABS}$ & $\mathrm{ABI} / \mathrm{ABS}$ & $\mathrm{ABI} / \mathrm{ABS}$ & IDBR \\
\hline Obs & $10,194,209$ & 78,896 & 78,896 & 78,896 & 78,896 & 78,896 & 78,896 & 78,896 & 78,896 & 78,896 & $4,845,158$ \\
\hline
\end{tabular}

PANEL B: Controls for industry, year, and firm fixed effects

\begin{tabular}{|c|c|c|c|c|c|c|c|c|c|c|c|}
\hline & (1) & (2) & (3) & (4) & (5) & (6) & (7) & (8) & (9) & (10) & (11) \\
\hline & $\begin{array}{c}\text { Ln(employ } \\
\text { ment) }\end{array}$ & $\begin{array}{c}\text { Ln(employ } \\
\text { ment) }\end{array}$ & $\begin{array}{c}\text { Ln(real } \\
\text { GVA) }\end{array}$ & $\begin{array}{c}\text { Ln(capital } \\
\text { stock) }\end{array}$ & $\begin{array}{c}\text { Ln(invest } \\
\text { ment) }\end{array}$ & $\begin{array}{c}\text { Ln(total } \\
\text { assets) }\end{array}$ & $\begin{array}{c}\text { Ln(fixed } \\
\text { assets) }\end{array}$ & $\begin{array}{c}\text { Ln(capital/ } \\
\text { labor) }\end{array}$ & $\begin{array}{c}\text { Ln(invest } \\
\text { ment/- } \\
\text { labor) }\end{array}$ & $\begin{array}{c}\text { Ln(invest } \\
\text { ment/- } \\
\text { capital ) }\end{array}$ & Survival \\
\hline $\begin{array}{l}\text { Ln(Repay } \\
\text { ment } \\
\text { prob.) }\end{array}$ & $\begin{array}{c}0.007 * * * \\
(0.002)\end{array}$ & $\begin{array}{c}0.047 * * \\
(0.020)\end{array}$ & $\begin{array}{c}0.410 * * * \\
(0.036)\end{array}$ & $\begin{array}{c}0.064 * * \\
(0.025)\end{array}$ & $\begin{array}{c}0.730 * * * \\
(0.073)\end{array}$ & $\begin{array}{c}0.292 * * * \\
(0.030)\end{array}$ & $\begin{array}{c}0.271 * * * \\
(0.047)\end{array}$ & $\begin{array}{c}0.018 \\
(0.028) \\
\end{array}$ & $\begin{array}{c}0.695 * * * \\
(0.073)\end{array}$ & $\begin{array}{c}0.670 * * * \\
(0.067)\end{array}$ & $\begin{array}{c}0.004 * * * \\
(0.001)\end{array}$ \\
\hline Data & IDBR & $\mathrm{ABI} / \mathrm{ABS}$ & $\mathrm{ABI} / \mathrm{ABS}$ & $\mathrm{ABI} / \mathrm{ABS}$ & $\mathrm{ABI} / \mathrm{ABS}$ & ORBIS & ORBIS & $\mathrm{ABI} / \mathrm{ABS}$ & $\mathrm{ABI} / \mathrm{ABS}$ & $\mathrm{ABI} / \mathrm{ABS}$ & IDBR \\
\hline Obs & $9,716,577$ & 57,400 & 57,400 & 57,400 & 57,400 & 57,400 & 57,400 & 57,400 & 57,400 & 57,400 & $4,597,208$ \\
\hline
\end{tabular}

Note: OLS estimates with standard errors clustered by firm in parentheses; $* * *$ indicates significance at the $1 \%, * * 5 \%$ and $* 10 \%$ level. We regress the logarithm of firm-level characteristics on the logarithm of the firm's repayment probability at the one-year horizon estimated using data at $t-1$. The sample in Columns (2)-(10) conditions on having non-missing values on all dependent variables. Panel B also conditions on a sub-sample with at least two firm-level observations (in order to be able to include firm fixed effects). The time period is 2005 to 2013. Industry and year dummies are included in all models. Predicted PDs are not used in column (11). 
Table A4: The effect of credit frictions on aggregate output, ABI/ABS Full sample (manufacturing and non-manufacturing)

\begin{tabular}{|c|c|c|c|c|c|c|c|}
\hline & \multirow{2}{*}{$\begin{array}{r}\text { Observations } \\
\text { (1) }\end{array}$} & \multicolumn{2}{|c|}{ Overall } & \multicolumn{2}{|c|}{ Scale } & \multicolumn{2}{|c|}{ TFP } \\
\hline & & $\begin{array}{l}(2) \\
\Theta_{t}\end{array}$ & $\begin{array}{c}\text { (3) } \\
\text { \% loss } \\
\text { of output }\end{array}$ & $\begin{array}{l}(4) \\
\Theta_{t}^{S}\end{array}$ & $\begin{array}{c}\text { (5) } \\
\% \text { loss } \\
\text { of output }\end{array}$ & $\begin{array}{l}(6) \\
\Theta_{t}^{T}\end{array}$ & $\begin{array}{c}\text { (7) } \\
\text { \% loss } \\
\text { of output }\end{array}$ \\
\hline 2005 & 40,083 & 0.211 & 27.737 & 0.233 & 25.924 & 0.903 & 1.813 \\
\hline 2006 & 33,742 & 0.229 & 26.452 & 0.254 & 24.593 & 0.902 & 1.859 \\
\hline 2007 & 37,220 & 0.240 & 25.740 & 0.266 & 23.879 & 0.902 & 1.860 \\
\hline 2008 & 39,365 & 0.241 & 25.685 & 0.266 & 23.857 & 0.904 & 1.828 \\
\hline 2009 & 37,814 & 0.193 & 29.044 & 0.217 & 26.957 & 0.888 & 2.087 \\
\hline 2010 & 38,123 & 0.207 & 27.969 & 0.232 & 25.983 & 0.894 & 1.986 \\
\hline 2011 & 37,561 & 0.205 & 28.137 & 0.232 & 25.921 & 0.883 & 2.216 \\
\hline 2012 & 37,644 & 0.209 & 27.834 & 0.236 & 25.677 & 0.886 & 2.157 \\
\hline 2013 & 36,605 & 0.207 & 27.987 & 0.234 & 25.845 & 0.886 & 2.142 \\
\hline Average & 37,573 & 0.216 & 27.398 & 0.241 & 25.404 & 0.894 & 1.994 \\
\hline
\end{tabular}

Notes: This table uses the ABI/ABS sample. $\Theta_{t}$ is the estimate of aggregate credit market frictions derived in Equation (18). Output loss is the proportionate fall in output as a result of credit frictions calculated using Equation (20). $\Theta_{t}^{S}$ is the scale component defined in Equation (22) and $\Theta_{t}^{T}$ is the TFP component defined in Equation (23). 
Table A5: The effect of credit frictions on aggregate output - Controlling for labor market frictions; ABI/ABS sample (manufacturing and nonmanufacturing)

\begin{tabular}{|c|c|c|c|c|c|c|c|c|c|}
\hline & \multicolumn{3}{|c|}{ All firms } & \multicolumn{3}{|c|}{ SMES } & \multicolumn{3}{|c|}{ Large firms } \\
\hline & $\begin{array}{l}\text { (1) } \\
\text { Obs }\end{array}$ & $\begin{array}{l}\text { (2) } \\
\Theta_{t}\end{array}$ & $\begin{array}{c}\text { (3) } \\
\% \text { loss } \\
\text { of output } \\
\end{array}$ & $\begin{array}{l}\text { (4) } \\
\text { Obs }\end{array}$ & $\begin{array}{l}\text { (5) } \\
\Theta_{t}\end{array}$ & $\begin{array}{c}\text { (6) } \\
\% \text { loss } \\
\text { of output } \\
\end{array}$ & $\begin{array}{l}\text { (7) } \\
\text { Obs }\end{array}$ & $\begin{array}{l}\text { (8) } \\
\Theta_{t}\end{array}$ & $\begin{array}{c}\text { (9) } \\
\% \text { loss } \\
\text { of output } \\
\end{array}$ \\
\hline 2005 & 27,392 & 0.005 & 26.440 & 23,164 & 0.006 & 28.606 & 4,228 & 0.213 & 21.719 \\
\hline 2006 & 23,749 & 0.005 & 25.085 & 19,885 & 0.005 & 27.254 & 3,864 & 0.212 & 19.443 \\
\hline 2007 & 26,085 & 0.007 & 21.229 & 21,758 & 0.005 & 24.662 & 4,327 & 0.268 & 19.378 \\
\hline 2008 & 24,361 & 0.006 & 22.910 & 19,682 & 0.008 & 23.926 & 4,679 & 0.195 & 16.182 \\
\hline 2009 & 24,260 & 0.008 & 22.942 & 19,624 & 0.007 & 27.009 & 4,636 & 0.251 & 19.417 \\
\hline 2010 & 24,259 & 0.004 & 22.870 & 19,899 & 0.004 & 25.270 & 4,360 & 0.213 & 15.481 \\
\hline 2011 & 24,039 & 0.009 & 18.846 & 19,468 & 0.005 & 25.032 & 4,571 & 0.142 & 21.037 \\
\hline 2012 & 24,646 & 0.004 & 22.347 & 20,009 & 0.004 & 26.082 & 4,637 & 0.413 & 10.204 \\
\hline 2013 & 23,637 & 0.004 & 24.154 & 18,904 & 0.004 & 26.076 & 4,733 & 0.198 & 12.228 \\
\hline Average & 24,714 & 0.006 & 22.980 & 20,266 & 0.005 & 25.991 & 4,448 & 0.234 & 17.232 \\
\hline
\end{tabular}

Notes: This table uses the ABI/ABS sample. Labor market distortions are estimated using data on value added and the wage bill and the parameter values specified in the text. Labor wedges are winsorized at the 1st and 99th percentiles by year. $\Theta_{t}$ is the estimate of aggregate credit market frictions derived in Equation (18). Output loss is the proportionate fall in output due to credit market frictions calculated using Equation (20). $\Theta_{t}^{S}$ is the scale component defined in Equation (22) and $\Theta_{t}^{T}$ is the TFP component defined in Equation (23). 
Table A6: The effect of credit frictions on aggregate output: different combinations of $\alpha$ (output-capital elasticity) and $\eta$ (returns to scale)

\begin{tabular}{|c|c|c|c|c|c|c|c|c|c|c|c|}
\hline$\eta$ & 0.75 & 0.77 & 0.79 & 0.81 & 0.83 & 0.85 & 0.87 & 0.89 & 0.91 & 0.93 & 0.95 \\
\hline \multicolumn{12}{|l|}{$\alpha$} \\
\hline 0.25 & 13.420 & 14.098 & 14.857 & 15.727 & 16.753 & 18.009 & 19.620 & 21.800 & 24.919 & 29.530 & 35.662 \\
\hline 0.27 & 14.855 & 15.635 & 16.512 & 17.523 & 18.722 & 20.197 & 22.094 & 24.656 & 28.268 & 33.428 & 39.349 \\
\hline 0.29 & 16.354 & 17.244 & 18.250 & 19.414 & 20.801 & 22.515 & 24.719 & 27.680 & 31.779 & 37.409 & 42.641 \\
\hline 0.31 & 17.919 & 18.927 & 20.072 & 21.403 & 22.994 & 24.963 & 27.494 & 30.862 & 35.427 & 41.411 & 45.521 \\
\hline 0.33 & 19.550 & 20.686 & 21.981 & 23.491 & 25.301 & 27.542 & 30.411 & 34.184 & 39.179 & 45.365 & 48.068 \\
\hline 0.35 & 21.250 & 22.523 & 23.978 & 25.679 & 27.721 & 30.247 & 33.462 & 37.629 & 43.004 & 49.196 & 50.390 \\
\hline 0.37 & 23.020 & 24.439 & 26.064 & 27.968 & 30.255 & 33.075 & 36.635 & 41.175 & 46.865 & 52.832 & 52.576 \\
\hline 0.39 & 24.861 & 26.435 & 28.241 & 30.358 & 32.898 & 36.018 & 39.916 & 44.798 & 50.722 & 56.215 & 54.680 \\
\hline 0.41 & 26.775 & 28.512 & 30.507 & 32.846 & 35.647 & 39.067 & 43.289 & 48.473 & 54.533 & 59.316 & 56.735 \\
\hline
\end{tabular}

Notes: This table shows the average output loss over our sample period 2005-2013 using the specification in Table 3 (Column (3)). We vary the parameter values as specified and recalculate the output losses. Our baseline parameter values are highlighted in grey. 
Table A7: The effect of credit frictions on aggregate output - using empirical factor shares to allow for heterogeneity in production functions

\begin{tabular}{|c|c|c|c|c|c|c|c|}
\hline & \multirow{2}{*}{$\begin{array}{l}\text { Observations } \\
\text { (1) }\end{array}$} & \multicolumn{2}{|r|}{ Overall } & \multicolumn{2}{|r|}{ Scale } & \multicolumn{2}{|r|}{ TFP } \\
\hline & & $\begin{array}{l}\text { (2) } \\
\Theta_{t}\end{array}$ & $\begin{array}{c}\text { (3) } \\
\text { Percentage loss of output }\end{array}$ & $\begin{array}{l}\text { (4) } \\
\Theta_{t}^{S}\end{array}$ & $\begin{array}{c}\text { (5) } \\
\text { Percentage loss of output }\end{array}$ & $\begin{array}{c}\text { (6) } \\
\Theta_{t}^{T}\end{array}$ & $\begin{array}{c}\text { (7) } \\
\text { Percentage loss of output } \\
\end{array}$ \\
\hline 2005 & $1,377,733$ & 0.277 & 24.719 & 0.296 & 23.460 & 0.937 & 1.260 \\
\hline 2006 & $1,414,221$ & 0.293 & 23.811 & 0.313 & 22.504 & 0.935 & 1.307 \\
\hline 2007 & $1,460,639$ & 0.300 & 23.403 & 0.321 & 22.103 & 0.935 & 1.300 \\
\hline 2008 & $1,545,919$ & 0.301 & 23.344 & 0.322 & 22.057 & 0.936 & 1.287 \\
\hline 2009 & $1,480,481$ & 0.259 & 25.860 & 0.278 & 24.482 & 0.931 & 1.378 \\
\hline 2010 & $1,459,680$ & 0.268 & 25.317 & 0.287 & 23.983 & 0.933 & 1.334 \\
\hline 2011 & $1,502,427$ & 0.273 & 24.960 & 0.295 & 23.481 & 0.926 & 1.479 \\
\hline 2012 & $1,502,665$ & 0.273 & 24.952 & 0.295 & 23.501 & 0.927 & 1.451 \\
\hline 2013 & $1,569,340$ & 0.276 & 24.776 & 0.297 & 23.377 & 0.930 & 1.399 \\
\hline Average & $1,479,234$ & 0.280 & 24.571 & 0.300 & 23.216 & 0.932 & 1.355 \\
\hline
\end{tabular}

Notes: This table uses the full IDBR sample (See Table 1). $\Theta_{t}$ is the estimate of aggregate credit market frictions derived in Equation (18). Output loss is the proportionate fall in output as a result of credit frictions calculated using Equation (20). $\Theta_{t}^{S}$ is the scale component defined in Equation (22) and $\Theta_{t}^{T}$ is the TFP component defined in Equation (23). This Table replicates the analysis of Table 3 using empirical estimates of $\alpha$ (see Appendix B) instead of setting the latter equal to one third in all industries. 
Table A8: The effect of credit frictions on aggregate output, increasing capital depreciation ( $\delta$ ) from $5 \%$ to $10 \%$

\begin{tabular}{|c|c|c|c|c|c|c|c|}
\hline & \multirow{3}{*}{$\begin{array}{c}\text { Observations } \\
(1)\end{array}$} & \multicolumn{2}{|r|}{ Overall } & \multicolumn{2}{|r|}{ Scale } & \multicolumn{2}{|r|}{ TFP } \\
\hline & & (2) & (3) & (4) & $(5)$ & $(6)$ & (7) \\
\hline & & $\Theta_{t}$ & Percentage loss of output & $\Theta_{t}^{S}$ & Percentage loss of output & $\Theta_{t}^{T}$ & Percentage loss of output \\
\hline 2005 & $1,377,733$ & 0.319 & 21.196 & 0.342 & 19.930 & 0.934 & 1.266 \\
\hline 2006 & $1,414,221$ & 0.345 & 19.896 & 0.370 & 18.611 & 0.934 & 1.285 \\
\hline 2007 & $1,460,639$ & 0.353 & 19.508 & 0.378 & 18.216 & 0.933 & 1.292 \\
\hline 2008 & $1,545,919$ & 0.357 & 19.337 & 0.382 & 18.058 & 0.934 & 1.279 \\
\hline 2009 & $1,480,481$ & 0.293 & 22.571 & 0.318 & 21.069 & 0.922 & 1.503 \\
\hline 2010 & $1,459,680$ & 0.303 & 22.023 & 0.329 & 20.540 & 0.923 & 1.483 \\
\hline 2011 & $1,502,427$ & 0.312 & 21.535 & 0.341 & 19.932 & 0.917 & 1.602 \\
\hline 2012 & $1,502,665$ & 0.311 & 21.630 & 0.339 & 20.024 & 0.917 & 1.605 \\
\hline 2013 & $1,569,340$ & 0.308 & 21.756 & 0.336 & 20.168 & 0.918 & 1.588 \\
\hline Average & $1,479,234$ & 0.322 & 21.050 & 0.348 & 19.616 & 0.926 & 1.434 \\
\hline
\end{tabular}

Notes: This table uses the full IDBR sample (See Table 1) and replicates the results of Table 3 with $\delta=0.1$ instead of $0.05 . \Theta_{t}$ is the estimate of aggregate credit market frictions derived in Equation (18). Output loss is the proportionate fall in output as a result of credit frictions calculated using Equation (20). $\Theta_{t}^{S}$ is the scale component defined in Equation (22) and $\Theta_{t}^{T}$ is the TFP component defined in Equation (23). 
Table A9: The effect of credit frictions on aggregate output using Solow residuals as a measure of productivity; ABI/ABS sample (manufacturing and non-manufacturing)

\begin{tabular}{|c|c|c|c|c|c|c|c|}
\hline & \multirow{2}{*}{$\begin{array}{c}\text { Observations } \\
(1)\end{array}$} & \multicolumn{2}{|c|}{ Overall } & \multicolumn{2}{|c|}{ Scale } & \multicolumn{2}{|c|}{ TFP } \\
\hline & & $\begin{array}{l}(2) \\
\Theta_{t}\end{array}$ & $\begin{array}{c}\text { (3) } \\
\text { \% loss } \\
\text { of output }\end{array}$ & $\begin{array}{l}(4) \\
\Theta_{t}^{S}\end{array}$ & $\begin{array}{c}(5) \\
\% \text { loss } \\
\text { of output }\end{array}$ & $\begin{array}{l}(6) \\
\Theta_{t}^{T}\end{array}$ & $\begin{array}{c}(7) \\
\text { \% loss } \\
\text { of output }\end{array}$ \\
\hline 2005 & 27,392 & 0.331 & 20.608 & 0.338 & 20.195 & 0.978 & 0.413 \\
\hline 2006 & 23,749 & 0.383 & 18.133 & 0.389 & 17.833 & 0.984 & 0.300 \\
\hline 2007 & 26,085 & 0.393 & 17.710 & 0.398 & 17.469 & 0.987 & 0.241 \\
\hline 2008 & 24,361 & 0.422 & 16.480 & 0.427 & 16.240 & 0.988 & 0.240 \\
\hline 2009 & 24,260 & 0.348 & 19.740 & 0.355 & 19.408 & 0.982 & 0.332 \\
\hline 2010 & 24,259 & 0.361 & 19.155 & 0.369 & 18.742 & 0.978 & 0.414 \\
\hline 2011 & 24,039 & 0.433 & 15.994 & 0.441 & 15.680 & 0.984 & 0.314 \\
\hline 2012 & 24,646 & 0.328 & 20.728 & 0.336 & 20.299 & 0.977 & 0.429 \\
\hline 2013 & 23,637 & 0.301 & 22.159 & 0.307 & 21.754 & 0.978 & 0.405 \\
\hline Average & 24,714 & 0.367 & 18.967 & 0.373 & 18.624 & 0.982 & 0.343 \\
\hline
\end{tabular}

Notes: The sample is the ABI/ABS. $\Theta_{t}$ is the estimate of aggregate credit market frictions derived in Equation (18). Output loss is the proportionate fall in output as a result of credit frictions calculated using Equation (20). $\Theta_{t}^{S}$ is the scale component defined in Equation (22) and $\Theta_{t}^{T}$ is the TFP component defined in Equation (23). Solow residuals are estimated as described in Appendix B. Ln(TFP) estimates are winsorized at the 1st and 99th percentiles by year. 
Table A10: The effect of credit frictions on aggregate output - allowing for time-varying funding costs, IDBR market sector

\begin{tabular}{|c|c|c|c|c|c|c|c|}
\hline & \multirow[t]{2}{*}{ Observations } & \multicolumn{2}{|r|}{ Overall } & \multicolumn{2}{|r|}{ Scale } & \multicolumn{2}{|r|}{ TFP } \\
\hline & & $\Theta_{t}$ & Percentage loss of output & $\Theta_{t}^{S}$ & Percentage loss of output & $\Theta_{t}^{T}$ & Percentage loss of output \\
\hline 2005 & $1,377,733$ & 0.205 & 28.106 & 0.228 & 26.267 & 0.902 & 1.839 \\
\hline 2006 & $1,414,221$ & 0.224 & 26.800 & 0.249 & 24.919 & 0.900 & 1.881 \\
\hline 2007 & $1,460,639$ & 0.253 & 24.929 & 0.279 & 23.161 & 0.907 & 1.768 \\
\hline 2008 & $1,545,919$ & 0.258 & 24.619 & 0.284 & 22.886 & 0.909 & 1.733 \\
\hline 2009 & $1,480,481$ & 0.127 & 35.014 & 0.148 & 32.405 & 0.857 & 2.609 \\
\hline 2010 & $1,459,680$ & 0.132 & 34.399 & 0.154 & 31.838 & 0.860 & 2.561 \\
\hline 2011 & $1,502,427$ & 0.145 & 33.170 & 0.170 & 30.432 & 0.853 & 2.738 \\
\hline 2012 & $1,502,665$ & 0.151 & 32.545 & 0.176 & 29.899 & 0.858 & 2.645 \\
\hline 2013 & $1,569,340$ & 0.134 & 34.209 & 0.158 & 31.450 & 0.850 & 2.759 \\
\hline Average & $1,479,234$ & 0.181 & 30.421 & 0.205 & 28.140 & 0.877 & 2.281 \\
\hline
\end{tabular}

Notes: This table uses the full IDBR sample (See Table 1). $\Theta_{t}$ is the estimate of aggregate credit market frictions derived in Equation (18). Output loss is the proportionate fall in output as a result of credit frictions calculated using Equation (20). $\Theta_{t}^{S}$ is the scale component defined in Equation (22) and $\Theta_{t}^{T}$ is the TFP component defined in Equation (23). This Table replicates the analysis of Table 3 using a time-varying estimate of funding costs as described in the text. 
Table A11: The effect of credit frictions on aggregate output - IDBR without predictions of Default Probabilities

\begin{tabular}{|c|c|c|c|c|c|c|c|}
\hline & (1) & & (3) & & (5) & & (7) \\
\hline & Observations & & Overall & & Scale & & TFP \\
\hline & & $\Theta_{t}$ & Percentage loss of output & $\Theta_{t}^{S}$ & Percentage loss of output & $\Theta_{t}^{T}$ & Percentage loss of output \\
\hline 2005 & 607,217 & 0.170 & 30.922 & 0.196 & 28.409 & 0.866 & 2.513 \\
\hline 2006 & 688,641 & 0.187 & 29.472 & 0.215 & 27.039 & 0.871 & 2.433 \\
\hline 2007 & 734,464 & 0.191 & 29.155 & 0.220 & 26.740 & 0.872 & 2.415 \\
\hline 2008 & 785,836 & 0.193 & 29.059 & 0.220 & 26.717 & 0.876 & 2.342 \\
\hline 2009 & 794,111 & 0.157 & 32.046 & 0.182 & 29.439 & 0.860 & 2.606 \\
\hline 2010 & 813,333 & 0.168 & 31.076 & 0.194 & 28.578 & 0.866 & 2.498 \\
\hline 2011 & 868,236 & 0.171 & 30.769 & 0.200 & 28.112 & 0.859 & 2.658 \\
\hline 2012 & 910,875 & 0.172 & 30.759 & 0.199 & 28.134 & 0.860 & 2.625 \\
\hline 2013 & 973,057 & 0.173 & 30.638 & 0.201 & 28.054 & 0.862 & 2.584 \\
\hline Average & 797,308 & 0.176 & 30.433 & 0.203 & 27.913 & 0.866 & 2.519 \\
\hline
\end{tabular}

Notes: This is the same as Table 3 except that we drop all predicted default probabilities. $\Theta_{t}$ is the estimate of aggregate credit market frictions derived in Equation (18). Output loss is the proportionate fall in output as a result of credit frictions calculated using Equation (20). $\Theta_{t}^{S}$ is the scale component defined in Equation (22) and $\Theta_{t}^{T}$ is the TFP component defined in Equation (23). 
Table A12: The effect of credit frictions on aggregate output, ABI/ABS sample without predictions of Default Probabilities

\begin{tabular}{|c|c|c|c|c|c|c|c|}
\hline & \multirow{2}{*}{$\frac{\text { Observations }}{(1)}$} & \multicolumn{2}{|c|}{ Overall } & \multicolumn{2}{|c|}{ Scale } & \multicolumn{2}{|c|}{ TFP } \\
\hline & & $\begin{array}{l}(2) \\
\Theta_{t}\end{array}$ & $\begin{array}{c}(3) \\
\% \text { loss } \\
\text { of output }\end{array}$ & $\begin{array}{l}(4) \\
\Theta_{t}^{S}\end{array}$ & $\begin{array}{c}(5) \\
\% \text { loss } \\
\text { of output }\end{array}$ & $\begin{array}{l}(6) \\
\Theta_{t}^{T}\end{array}$ & $\begin{array}{c}(7) \\
\text { \% loss } \\
\text { of output }\end{array}$ \\
\hline 2005 & 25,019 & 0.176 & 30.408 & 0.202 & 27.993 & 0.871 & 2.415 \\
\hline 2006 & 22,659 & 0.192 & 29.095 & 0.220 & 26.746 & 0.875 & 2.349 \\
\hline 2007 & 25,233 & 0.202 & 28.374 & 0.230 & 26.055 & 0.877 & 2.319 \\
\hline 2008 & 27,361 & 0.203 & 28.302 & 0.230 & 26.090 & 0.883 & 2.212 \\
\hline 2009 & 27,087 & 0.160 & 31.714 & 0.186 & 29.138 & 0.862 & 2.575 \\
\hline 2010 & 26,336 & 0.178 & 30.235 & 0.204 & 27.837 & 0.872 & 2.398 \\
\hline 2011 & 27,233 & 0.177 & 30.281 & 0.205 & 27.732 & 0.864 & 2.550 \\
\hline 2012 & 28,243 & 0.182 & 29.878 & 0.210 & 27.407 & 0.869 & 2.471 \\
\hline 2013 & 27,849 & 0.178 & 30.199 & 0.206 & 27.703 & 0.867 & 2.495 \\
\hline Average & 26,336 & 0.183 & 29.832 & 0.210 & 27.411 & 0.871 & 2.421 \\
\hline
\end{tabular}

Notes: This is the same as Table A4, except that we drop all predicted default probabilities. $\Theta_{t}$ is the estimate of aggregate credit market frictions derived in

Equation (18). Output loss is the proportionate fall in output as a result of credit frictions calculated using Equation (20). $\Theta_{t}^{S}$ is the scale component defined in Equation (22) and $\Theta_{t}^{T}$ is the TFP component defined in Equation (23). 
Table A13: The effect of credit frictions on expected (instead of realized) aggregate output; IDBR market sector

\begin{tabular}{|c|c|c|c|c|c|c|c|c|c|}
\hline & \multicolumn{3}{|c|}{ All firms } & \multicolumn{3}{|c|}{ SMES } & \multicolumn{3}{|c|}{ Large firms } \\
\hline & (1) & (2) & (3) & (4) & (5) & (6) & (7) & $(8)$ & (9) \\
\hline & Obs & $\Theta_{t}^{e}$ & $\begin{array}{c}\text { Expected } \\
\text { output loss }\end{array}$ & $\Theta_{t}^{e}$ & Theta & $\begin{array}{c}\text { Expected } \\
\text { output loss }\end{array}$ & Obs & $\Theta_{t}^{e}$ & $\begin{array}{c}\text { Expected } \\
\text { output loss }\end{array}$ \\
\hline 2005 & $1,377,733$ & 0.195 & 28.859 & $1,371,906$ & 0.140 & 33.627 & 5,827 & 0.303 & 22.029 \\
\hline 2006 & $1,414,221$ & 0.216 & 27.379 & $1,408,569$ & 0.155 & 32.167 & 5,652 & 0.339 & 20.202 \\
\hline 2007 & $1,460,639$ & 0.221 & 26.967 & $1,455,388$ & 0.161 & 31.660 & 5,251 & 0.342 & 20.021 \\
\hline 2008 & $1,545,919$ & 0.227 & 26.584 & $1,540,225$ & 0.166 & 31.236 & 5,694 & 0.340 & 20.152 \\
\hline 2009 & $1,480,481$ & 0.179 & 30.170 & $1,474,989$ & 0.118 & 35.933 & 5,492 & 0.303 & 22.055 \\
\hline 2010 & $1,459,680$ & 0.188 & 29.416 & $1,454,545$ & 0.119 & 35.882 & 5,135 & 0.338 & 20.251 \\
\hline 2011 & $1,502,427$ & 0.190 & 29.282 & $1,497,247$ & 0.134 & 34.237 & 5,180 & 0.309 & 21.719 \\
\hline 2012 & $1,502,665$ & 0.192 & 29.147 & $1,497,445$ & 0.125 & 35.160 & 5,220 & 0.333 & 20.491 \\
\hline 2013 & $1,569,340$ & 0.192 & 29.083 & $1,564,028$ & 0.117 & 36.023 & 5,312 & 0.352 & 19.568 \\
\hline Average & $1,479,234$ & 0.200 & 28.543 & $1,473,816$ & 0.137 & 33.992 & 5,418 & 0.329 & 20.721 \\
\hline
\end{tabular}

Notes: This table uses the IDBR sample. Estimates are broken down by firm size (SMEs have under 250 employees; large firms have 250 employees or more). $\Theta_{t}^{e}$ is the estimate of aggregate credit market frictions and expected output loss is the expected output loss due to credit market frictions (see text). 
Table A14: The effect of credit frictions on aggregate output: broken down by sector

\begin{tabular}{|c|c|c|c|c|c|c|c|c|c|}
\hline & \multicolumn{3}{|c|}{ D: Manufacturing } & \multicolumn{3}{|c|}{ F: Construction } & \multicolumn{3}{|c|}{ G: Wholesale and retail trade } \\
\hline & Obs & $\Theta_{t}$ & Output loss & Obs & $\Theta_{t}$ & Output loss & Obs & $\Theta_{t}$ & Output loss \\
\hline 2005 & 145,059 & 0.204 & 28.220 & 210,043 & 0.163 & 31.489 & 362,160 & 0.255 & 24.794 \\
\hline 2006 & 142,834 & 0.232 & 26.277 & 217,979 & 0.179 & 30.134 & 360,068 & 0.260 & 24.473 \\
\hline 2007 & 137,759 & 0.247 & 25.294 & 227,198 & 0.172 & 30.701 & 357,457 & 0.282 & 23.214 \\
\hline 2008 & 134,912 & 0.233 & 26.197 & 236,370 & 0.174 & 30.566 & 357,237 & 0.310 & 21.684 \\
\hline 2009 & 127,643 & 0.200 & 28.482 & 225,071 & 0.135 & 34.144 & 345,345 & 0.282 & 23.188 \\
\hline 2010 & 122,328 & 0.220 & 27.092 & 217,882 & 0.136 & 34.032 & 343,645 & 0.296 & 22.410 \\
\hline 2011 & 119,688 & 0.240 & 25.727 & 221,237 & 0.149 & 32.714 & 346,940 & 0.255 & 24.818 \\
\hline 2012 & 119,445 & 0.219 & 27.143 & 217,092 & 0.137 & 33.883 & 344,502 & 0.289 & 22.808 \\
\hline 2013 & 121,175 & 0.222 & 26.901 & 222,202 & 0.117 & 36.044 & 348,405 & 0.297 & 22.346 \\
\hline \multirow[t]{3}{*}{ Average } & 130,094 & 0.224 & 26.8 & 221,675 & 0.151 & 32.6 & 351,751 & 0.281 & 23.3 \\
\hline & \multicolumn{3}{|c|}{ H: Hotels and restaurants } & \multicolumn{3}{|c|}{ I: Transport, storage and communication } & \multicolumn{3}{|c|}{$\begin{array}{l}\text { K: Real estate, renting and business activities } \\
\text { (minus real estate) }\end{array}$} \\
\hline & Obs & $\Theta_{t}$ & Output loss & Obs & $\Theta_{t}$ & Output loss & Obs & $\Theta_{t}$ & Output loss \\
\hline 2005 & 125,877 & 0.186 & 29.545 & 78,512 & 0.249 & 25.146 & 456,082 & 0.174 & 30.563 \\
\hline 2006 & 128,089 & 0.210 & 27.798 & 78,848 & 0.309 & 21.691 & 486,403 & 0.190 & 29.261 \\
\hline 2007 & 129,023 & 0.207 & 27.974 & 78,998 & 0.269 & 23.965 & 530,204 & 0.197 & 28.720 \\
\hline 2008 & 130,651 & 0.223 & 26.879 & 79,525 & 0.270 & 23.898 & 607,224 & 0.196 & 28.819 \\
\hline 2009 & 122,655 & 0.126 & 35.092 & 75,266 & 0.224 & 26.807 & 584,501 & 0.128 & 34.908 \\
\hline 2010 & 121,311 & 0.127 & 34.949 & 73,717 & 0.240 & 25.717 & 580,797 & 0.128 & 34.903 \\
\hline 2011 & 123,895 & 0.142 & 33.473 & 75,009 & 0.254 & 24.876 & 615,658 & 0.152 & 32.520 \\
\hline 2012 & 122,247 & 0.139 & 33.682 & 75,809 & 0.252 & 24.958 & 623,570 & 0.140 & 33.661 \\
\hline 2013 & 124,653 & 0.125 & 35.158 & 79,819 & 0.300 & 22.178 & 673,086 & 0.130 & 34.668 \\
\hline Average & 125,378 & 0.165 & 31.6 & 77,278 & 0.263 & 24.4 & 573,058 & 0.159 & 32.0 \\
\hline
\end{tabular}

Notes: This table uses the IDBR sample. Estimates are broken down by each of the 6 segments ("divisions") of the UK market economy. The methodology of Table 3 is used to calculate the output losses. 